AN ECOPHYSIOLOGICAL APPROACH TO CROP LOSSES, EXEMPLIFIED IN THE SYSTEM WHEAT, LEAF RUST, AND GLUME BLOTCH 
Dit proefschrift met stellingen van Antonius Franciscus van der Wal, landbouwkundig ingenieur, geboren te Arnhem op 18 augustus 1943, is goedgekeurd door de promotor, Dr. J.C. Zadoks, lector in de Fytopathologie.

De Rector Magnificus van de Landbouwhogeschool, H. A. Leniger

Wageningen, 30 november 1974 


\section{1,610}

A.F. van der Wal

\section{An ecophysiological approach to crop losses exemplified in the system wheat, leaf rust, and glume blotch}

\section{Proefschrift}

ter verkrijging van de graad van doctor in de Iandbouwwetenschappen, op gezag van de Rector Magnificus, Dr.Ir. J.P.H. van der Want, hoogleraar in de Virologie, in het openbaar te verdedigen op woensdag 29 januari 1975 des namiddags te vier uur in de Aula van de Landbouwhogeschool te Wageningen

Laboratorium voor Fytopathologie, Landbouwhogeschool, Wageningen

$$
150+24+2 \cdots 2
$$


REFERENCES

APPENDIX

An ecophysiological approach to crop losses, exemplified in the system wheat, rust, and glume blotch

I. A simple and accurate balance for the continuous measuring and recording of (evapo-) transpiration of plants in indoor experiments. P. Tegelaar \& A.F. van der Wal. Neth. J. Pl. Path. 80(1974): 77-84.

II. Development, growth, and transpiration of uninfected plants and plants infected with $P$. recondita f.sp. triticina and/or Septoria nodomm in a climate chamber experiment. A.F. van der Wal and M.C. Cowan. Neth. J. P1. Path. 80(1974): 192-214.

III. Effects of soil-water potential on development, growth, transpiration, symtotons, and spore production of leaf rust-infected wheat. A.F. van der Wal, Hanneke Smeitink \& C.G. Maan. Neth. J. P1. Path. 81(1975): 1-13.

IV. Water flow and leaf-water potential of uninfected wheat plants and plants infected with $P$. recondita f.sp. triticina. M.C. Cowan and A.F. van der Wal. Neth. J. P1. Path. 81(1975): 49-57. 


\section{Voorwoord}

$\mathrm{Nu}$, vijf jaar na het begin van het onderzoek, waarvan een gedeelte is afgerond met dit proefschrift, is het een goede gelegenheid terug te zien op het verloop van het werk en het resultaat ervan. Allereerst gaat mijn dank uit naar mijn ouders, die mij in staat stelden te gaan studeren en die veel bijdroegen tot de voltooiing van de studie. Veel van de ideeën, die ten gronslag liggen aan dit proefschrift, werden opgedaan voordat ik in Wageningen ging studeren, door toedoen van Dr.Ir. W. Feekes tijdens mijn vele jaren durende 'seizoenarbeid' op Geertsema's Veredelingsbedrijf in de N.O.P. Zijn daadwerkelijke steun tijdens en na mijn studie in de vorm van adviezen, introducties en reisfaciliteiten zij hier dankbaar vermeld. Van de heer $D$.Th. Wieten leerde ik de praktijk van de tarweveredeling, alsmede enkele organisatorische aspecten van de bedrijfsvoering. Hiervoor, en voor het plezierige contact, reeds vanaf 1957, ben ik dankbaar. Mijn promotor, Dr. J.C. Zadoks, leerde ik al voor mijn studie aan de LH kennen. Naast alle dingen, die iedereen aan zijn promotor verschuldigd is, wil ik hier noemen, het tegenwicht dat hij vormde bij het in evenwicht houden van mijn wereld van ideeën en datgene wat zou kunnen leiden tot een bijdrage aan de wetenschap. Voor de geboden vrijheid bij onderzoek en zijn steun bij het schrijven van de artikelen en het proefschrift ben ik hem zeer erkentelijk. Prof.Dr.Ir. J. Dekker ben ik mede erkentelijk voor de mij geboden gelegenheid aan het Laboratorium voor Fytopathologie dit onderzoek te verrichten, waarbij ik de door hem getoonde belangstelling waardeer. Dr. K. Schurer (TFDL, Wageningen) en P. Tegelaar ing. (IWECO-TNO, Delft) hebben beslissend bijgedragen aan de ontwikkeling van respectievelijk de electronische bladnat schrijver én de electronische balans. Het geduld, waarmee de heren H.A. Gerritsen, H. Melgers en C.G.M. Derksen van de Technische Dienst steeds weer de klimaatkamers aanpasten aan nieuwe wensen, en behulpzaam waren bij de opbouw van de meetapparatuur, stel ik zeer op prijs. Het werk verricht door de Instrumentmakerij, met name door de heren G. van Surksum en 0. van Geffen, heb ik buitengewoon gewaardeerd. Voor de plezierige samenwerking met 
Dr. Mark C. Cowan (U.K.), die bij de voortgang van mijn onderzoek zeer waardevol is gebleken, betuig ik hem hier mijn dank. Door de voorbereiding van de werkgroep 'CEPT' en de eerste gezamenlijke proeven op de 'Eest' werden de reeds bestaande contacten met Ir. M.M. de Vos, Ir. L.A.M. Slootmaker en Ir. J. Goudriaan verstevigd. De vele uren die ik met hen, speciaal met Ir. de Vos heb doorgebracht, vermeld $i k$ hier in grote erkentelijkheid. Mijn waardering gaat uit naar de dames van de afdeling tekstverwerking, van de secretarie van de afdeling Fytopathologie, en naar de heren G. Eimers, W.C.Th. Middelplaats en F.J.J. von Planta die type-, foto- en tekenwerk verzorgden, terwijl ook de goede service van de bibliotheek van het Binnenhaven complex vermelding verdient. Jolanda, nu mevr. J. Haanstra-Verbeek, fungeerde als technisch assistente in de periode van de opbouw van het onderzoek; in februari 1972 werd haar plaats ingenomen door Corrie Geerds. Hun enthousiasme bij het werk, ook buiten 'kantooruren', was voor mij een grote steun. De redactie van het Neth. J. P1. Path. en de bureauredacteur de heer J.H. Lueks ben ik erkentelijk voor hun aandeel in het tempo waarmee artikelen en proefschrift zijn verschenen. Voorts wil ik allen danken die bijgedragen hebben aan mijn opleiding en/of door hun collegialiteit mij tot steun geweest zijn.

De onbaatzuchtige steun die mijn schoonvader, de heer H.J.A. van Becku, gaf in de vorm van de correctie van het Engels, verdient bijzondere vermelding. Het meeste typewerk, met inbegrip van het opwerken van de 'manuscripten', is door Maria verzorgd. Zij kon de drukte van ons jonge gezin combineren met deze extra hulp aan mij. Onze kinderen hebben bij voortduring gezorgd voor de niet altijd even noodzakelijke afleiding, waarmee dan gezegd is, dat dit proefschrift mede door familiebijdragen tot stand is gekomen. 


\section{The ecophysiological approach}

Theoretically, there is a little doubt as to the importance of plant physiology to agriculture, horticulture and forestry, or ecology at large. Practically, however, there may be more doubt since many plant physiological studies give the impression that plant physiologists have lost out of sight one of the original aims of plant physiology as expressed by Pfeffer (1897): "Die Physiologie hat die Aufgabe, die Vorgänge im lebenden Organismus nach Mass und Zahl festzustellen, auf ihre Ursachen zurückzuführen und in ihrer Bedeutung für den Organismus kennenzulernen". The latter part of the phrase regards ecologists and agriculturists. The present state of affairs seems to be the consequence of only a partial fulfilment of Pfeffer's statement, viz. "die Vorgänge nach Mass und Zahl festzustellen", which may have attracted the more research workers as more and better equipment became available. The predominance of attention paid to the lower levels of organisation in the sequence 'organelles, cells, tissues, organs, organisms, populations, communities, ecosystems, and biosphere' has, as stated by Brouwer (1973), enlarged the gap between plant physiology and ecology. This has already led to a situation in which the results obtained are so detailed that they do not contribute sufficiently to an understanding of the functioning of the organism.

There is an area where plant physiology meets, or should meet, ecology and agronomy. Here, plant pathology introduces new views and concepts. The diseased plant is a new entity, another individual, but of a next higher organisation level. Pathogen and host plant are two species, one might in some cases even say two individuals, confined to grow together for a period of time. This entity, aegricorpus as it is called by Loegering (1972) responds to its environment in a way characteristic of that entity. An aegricorpus is created by infection of the host with the pathogen. The appendix contains reports on experiments in which responses of various aegricorpora to various environments are followed throughout their lifetime. 
Ecology begins where two species meet. The techniques applied here are rather physiological ones. To characterize the approach to crop losses presented here, the words ecology and physiology should be combined to one term. Since the author feels this approach to have its emphasis on physiology, he calls it an ecophysiological approach, and not a physiological-ecological approach (Colinvaux, 1973).

The ain of the work is to provide information to be of use in disease prevention and control. Effects of plant breeding and crop management on disease become concrete in the response of the aegricorpus to its environment. The ecophysiological approach is an essential and, up to now, lacking element in crop loss studies, as will be shown below. 


\section{Crop loss studies}

\section{Introduction}

Crop loss studies have been made for a number of years (James, 1974) to inventory anount, place, time, and causes of loss, in order to provide a basis for the allocation of money in programs of loss reduction. As chemical control has become available in recent years, and the magnitude of crop losses due to pathogens has become apparent in its full size (De Jong, 1970), crop loss studies will be of use in crop management as part of a strategy for loss prevention. The importance of crop loss studies has been recognized by the FAO, which organized a Symposium on Crop Losses in 1967 in Rome, and published a Crop Loss Assessment Manual in 1971. The general methods of disease-loss appraisal, as described by Large (1966), involve two phases, viz. field experiments and surveys.

\section{Field experiments}

Estimates of crop losses caused by harmful organisms can be derived from simple standardized experiments designed for this purpose, and conducted on farms and experimental stations. These experiments should be located equally to represent the range of nomal farm practices. In some cases it is possible to stratify the crop areas according to severity of disease attack. These field experiments have much in common with the usual agrononic field trials because of the variability caused by such factors as crop cultivars and sequences, soil type and fertility, time of planting, temperature, rainfall, etc. A further complication is the pathogen component and its interaction with the crop plant under the given set of environmental conditions. It should be noted that absolute values for losses cannot be obtained in practice since the disease-free reference is difficult to realise in the field. However, useful results can be obtained from properly designed and well-conducted field experiments (LeClerg, 1970). 
Correlation and regression are the two statistical procedures for evaluating the relationship between pathogen intensity and yield reduction. A plotting of points for each level of pathogen intensity versus corresponding yield reduction will usually indicate the nature of the regression relationship. Fig. 1 gives a generalized picture of a regression of yield on pathogen intensity (Justesen and Tasmes, 1960; Tammes, 1961).

Fig. 1. A generalized picture of the relation between yield expressed in $\%$ and disease (severity) (\%). The line 1 represents the yield loss in $\%$ at disease severity d.

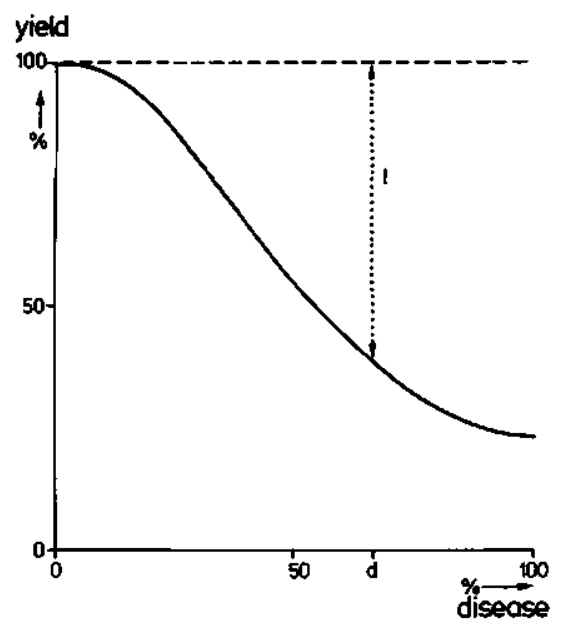

Fig. 1. Een gegeneraliseerd beeld van het verband tussen opbrengst (yield) en aantastingsgraad (disease), beide uitgedrukt in percentages. Het $1 \mathrm{ijn}$ stuk 1 geeft de opbrengstderving in $\%$ aan bij antastingsgraad $d$.

The abscissa represents disease 'severity' in various plots or treatments at a given time. When, however, disease progress is taken into account by assessing disease severity repeatedly, nultiple regression can be applied (James, 1974).

Usua11y, more than one pathogen at a time interferes with crop growth (Van der Wal et al., 1970; Van der Wal and Zadoks, 1971). Curve 1 of Fig. 2 indicates the relation between yield and percentage of infection of the first occurring pathogen, whereas curve 2 represents yield versus percentage of infection by the second pathogen in absence of the first. At any degree of infection by the first pathogen, the severity of the second pathogen and the corresponding yield is given by curve $1+2$. With a simple curve fitting technique a reasonable impression can be obtained about effects of one or 
Fig. 2. A generalized picture of the relation between yield (\%) and disease 'severity' (\%) in the case of pathogen 1 (curve 1) and pathogen 2 (curve 2) alone, and when pathogen 1 and 2 both are present in the same crop (curve $1+2$ ). In the latter case, the abscissa indicates the disease severity of the first occurring pathogen, whereas the circles stand for severity classes of pathogen 2; the more a circle is filled, the higher the severity of this pathogen. This figure shows interaction of both diseases on yield, $a+(a+b) \neq$ $a+b+c$, and mutual interaction of the pathogens, where in curve $1+2$ high severities for pathogen 2 are correlated with high severities for pathogen 1 .

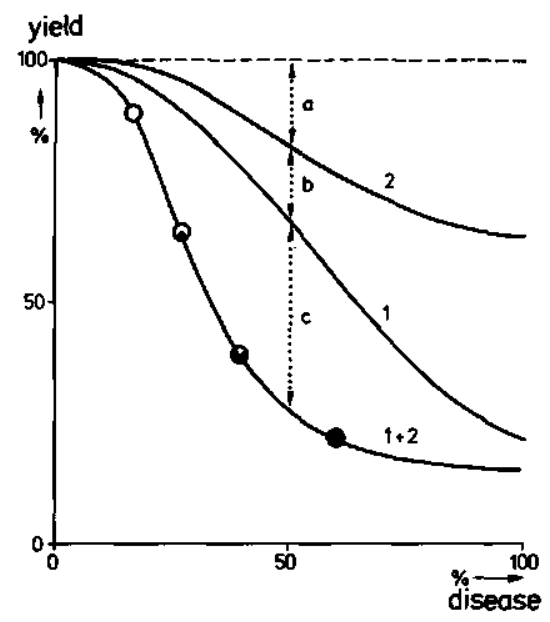

Fig. 2. Een gegeneraliseerd beeld van het verband tussen opbrengst (yield) en aantastingsgraad (disease), beide uitgedrukt in percentages, wanneer pathogeen 1 (curve 1) en pathogeen 2 (curve 2) elk afzonderlijk voorkomen, en voor het geval beide pathogenen samen voorkomen in het gewas (curve $1+2$ ). In het laatste geval geeft de abscis de aantastingsgraad voor pathogeen 1 aan, terwij1 de aantastingsgraad voor pathogeen 2 door cirkels op curve $1+2$ aangegeven wordt. Meer gevulde cirkels stellen hogere aantastingsgraden voor. De figuur toont interactie van beide pathogenen op de opbrengst, $a+(a+b) \neq$ $a+b+c$, en de interactie van de beide pathogenen onderling, waar hogere aantastingsgraden van pathogeen 2 met hoge waarden van pathogeen 1 samengaan.

two pathogens on yield and/or on their interaction. Under natural conditions many interactions between crop, pathogens, and other injurious agents may take place. In such instances, the hypothesis of independence of action of the various agents leads to unreliable estimators. Objective estimates of losses require the estimation of all possible interactions between pathogens and crop plants and the contribution of each to overall losses (LeClerq, 1970). The problem is conplicated by interaction of pathogen and of crop with soil moisture, soil fertility, and cultivar. According to LeClerq (1970), the number of possible interactions is so large that in practice there is little chance of identifying them all by statistical means.

To assess the effect of a particular pathogen in a given year and a given place, 


\section{Some aspects of development, growth and transpiration of wheat}

The adaptability of wheat to various soils and climatic conditions is probably superior to that of any other plant. Most areas in which wheat is grown are found between 40 and 60 degrees NL and 27 to 40 degrees SL, but wheat can be grown from beyond the Arctic Circle to the Equator.

Seedling development

Germination starts with the uptake of water to almost the same amount as the seed had lost during the last stages of ripening. Energy for growth is supplied by the seed itself. Seedling independence is reached when the dry weight of the seedling (minus seed remains) is equal to the initial weight of the grain. The achievement of seedling independence through photosynthesis marks the beginning of the vegetative phase of growth. By this time, the seedling usually has the first two leaves unfolded and the tip of the third leaf is just visible.

Presowing treatments like vernalization and 'hardening' against drought influence rates of growth and development, and therefore presowing treatments have to be mentioned in studies where these rates are considered.

\section{Leaf growth}

The laminae of wheat produce the major part of the assimilates, the contribution from the leaf sheaths being relatively unimportant during the vegetative stage. The rates at which new leaves appear and unfold, depend on conditions of water regime, tenperature, light intensity and day length under which the plant is growing, and the same holds for the shape and size of the mature laminae. As long as the young leaf depends on assimilates supplied by the more mature leaves, the effects of temperature and radiation on the young leaf parallel those on the plant as a whole. Direct morphogenetic effects of light may begin even before the young leaf emerges, because of light transmission through the sheaths of the preceding leaf. 
Intensive growth requires a high hydration level. Therefore, effects of soilwater potential on leaf growth have been studied and the results are presented in the appendix.

\section{Tillering}

A bud is usually present at the base of coleoptile, prophyllum, and leaf, and under suitable conditions such buds can grow out to tillers. The sequence of tillering in wheat is quite regular. Each tiller develops its own root system. A single plant can develop over a 100 tillers, but in the crop situation the tiller number is usually limited and shows a picture of e.g. 7 shoots per plant, usually 4 to 5 primary tillers and a few secondary tillers from the first nodes of the second and third tillers. Higher order axes are formed successively, and the tillers that die are mostly but not always the last formed. Once a tiller has entered the reproductive phase it will normally survive, and when a reproductive tiller dies, its decline usually starts before the stem begins to elongate. At flowering time, little more then 2 tillers per plant survive in a dense crop in N.W. Europe. Nutrients, especially nitrogen, water supply, and light seen to control the tillering in wheat. When a lateral bud begins to expand to form a tiller, its need for substrates must be met from elsewhere in the plant. It has been shown that in young wheat plants carbon can move from a parent shoot to a young tiller, but as shoots become older, the movement of carbon from shoot to shoot is progressively restricted. The death of tillers is associated with a flow of minerals and possibly also nitrogen and carbon from the dying to the surviving tillers. Notwithstanding the dying of tillers, there is no interruption in growth of the plant as a whole. It is generally concluded that either dry matter is transferred from dying to surviving shoots, or that other shoots grow faster.

\section{Stem elongation}

After the induction of flowering in wheat plants, the internodes, hitherto very short, begin to elongate. They grow by the production of new cells in the intercalary meristems of the lower parts of each of the internodes and by the extension of these cells. The leaf sheaths elongate at approximately the same time. The lower internodes usually elongate less than the higher ones. During the elongation of the internodes, the nutrient supply to the developing ear, leaves, and buds through the vascular system must be more or less 
intermuted as new vascular elements are differentiating and the older protoxylem and protophloem are stretched or disrupted. Shortage of water in this period results in smaller stems, mainly due to reduced elongation of higher internodes. The growth of stems in wheat is markedly stimulated shortly after floral initiation.

\section{Flowering}

The onset of floral initiation is marked by the transformation of the apical growing point into floral primordia, and the production of flower initials. The change may have little effect on growth until previously formed leaves are fully expanded and the flag leaves have emerged. At this point, the leaf area of the wheat plant is close to its maximum. Later, leaf emergence ceases, first on the main shoot and then on tillers of succeeding orders. Leaf area per plant declines owing to senescence and/or disease.

Root growth

Root growth in wheat slows down or stops at about the time of ear formation. In normally developing isolated plants, the shoot/root ratio increases as development proceeds. Transpiration per gram shoot weight decreases accordingly, partly because of mutual shading of the leaves and possibly also due to a progressively xeromorphic structure of the successive leaves. Equilibrium is established in such a way that the water absorption per gram root weight remains constant during the whole growth period.

Ear emergence and grain ripening

Between ear emergence and grain ripening, photosynthesis by the ear becones of increasing importance for grain filling. Most of the assimilates not lost by respiration go into the grain. Leaves, sheaths, and stems below the flag leaf node usually contribute up to $c .15 \%$ to final grain weight. The photosynthetic activity of the inflorescence of wheat contributes 20 to $50 \%$ of the grain yield at harvest. The remainder of the grain yield is produced by the flag leaf, its sheath, and the peduncle. 
In the latter half of the last century an interest started in possible relationships between yield and rainfall. The statistical approach was improved when attempts were made to correlate yields with rainfall at different seasons and over various short periods of time rather than with annual rainfall. Russian workers pioneered in this approach and before the end of the century Brounov (Salter and Goode, 1967), had reported a high correlation between the yield of oats and the amount of rain which fell during the ten days' period preceding the heading stage of the crop. Brounov applied the term 'critical period' for those stages of development at which the plant appeared to be particularly sensitive to the effect of rain. The beginning of this period of extra sensitivity to water closely coincides with the first stages in the development of the reproductive organs, and this in turn occurs at some time during the late tillering stage or during shooting. The length of this 'rain sensitive' period usually ends when fertilization occurs. It appears that the main effect of water supply during this critical period of plant development is an influence on the number of grains per ear.

Moisture conditions at other growth stages can effect grain yields by their influence on any of the yield components. Tiller number, and hence ear number, is affected by water supply in the early stages of growth (Van der Wal et al., 1975), whereas the size of the grain is affected by water supply after flowering. The beginning of reproductive development in wheat mostly coincides with the maximum of vegetative growth. At this time, when potential (evapo-) transpiration is near its maximu, the rate of root growth is greatly reduced, and it may cease altogether. After flowering, root weight may decrease (Van der Wal and Cowan, 1974).

For many years, attempts have been made to localize the 'critical period' when water 'stress' has the greatest effect on yield. It may be concluded that a high growth activity in plant tissue is usually connected with a high plant-water potential. During ontogenesis, high hydration levels are associated with the maintenance of physiological characteristics of 'youth', chiefly the continuation of cell division and of extension growth, and morphological characteristics such as few and large stomata, and a thin cuticle. These characteristics influence the rate of growth and development such as leaf area and number of fertile tillers, spikelets and flowers. 'Young' leaves show high photosynthetic activity, which in turn increases the growth 
rate. However, the higher transpiration rate in 'young' leaves controlled by a more sensitive reactivity of the stomata as compared to 'old' leaves, often results in a water deficit. Sudden drought periods can have a serious influence in all stages of development, the effects being more serious the higher the soil-water potential at which the plants have grown.

In conclusion, water shortage reduces yield in all stages, but causes the greatest reduction when it occurs during shooting and heading. Seen from an ecophysiological viewpoint, there are no distinct critical periods. 


\section{Effects of leaf rust and Septoria nodorum on develop. ment, growth and transpiration of wheat}

Leaf invading fungi can be classified into two main groups, viz, biotrophic and perthotrophic pathogens (Oort, 1963). In recognition of this classification, one fungus of either group was used in the present crop loss studies. Leaf rust ( $P$. recondita Rob. ex Desm. f.sp. triticina Eriks.) represents the biotrophic fungi, whereas Septoria nodomum Berk. stands for the perthotrophic species.

The following qualitative picture about the interference of leaf rust and $S$. nodorum with wheat is derived from the literature, viz. Brönnimann, 1968; Brömnimann et al., 1972; Bushnell and Rowe11, 1968; Doodson et al., 1964 a, b, c; Johnson et al., 1968; Martin and Hendrix, 1974; Samborski and Shaw, 1956; Scharen and Taylor, 1968; Scharen and Krupinsky, 1969; Shaw, 1964; Shaw and Samborski, 1957; Shipton, 1968; Shipton et a1., 1971; Yarwood, 1953; Yarwood and Cohen, 1951; Yirgou and Caldwe11, 1968.

Rust

After rust infection and before pustules become visible, transpiration rate may already increase, probably owing to interference of the growing rust with the control of the stomata. When the epidermis is disrupted by the pustules, transpiration rate usually increases, supposedly owing to decreasing diffusion resistance in the leaf, and without reinfection new (secondary) pustulus are formed in the course of time. Chlorosis and necrosis may be found around the pustules. Growth of the leaf is hampered, owing to the lowering leaf-water potential. Photosynthesis is initially increased, but slows down later.

In uninfected plants, excessive water loss may stop leaf growth. Photosynthesis, however, may continue at its original level for some time. In that case the temporary surplus of assimilates can be translocated to the 
roots, leading to a temporary increase in the rate of root growth. In rusted plants, retention of assinilates in the infected leaf occurs, and consequently there is no increase in root growth when leaf growth ceases. Infections during the vegetative phase cause, therefore, retardation of plant growth. Heading may be delayed, and, in cases of water shortage, abortion of kernels is likely to occur (Cowan and Van der Wal, 1975). Infections during ripening rapidly reduce the turgid leaf area, and weaken the root systern accordingly.

\section{Septoria nodorum}

At any stage of development $S$. nodomm may invade and kill plant tissue. Heads are protected from infection as long as they are covered by leaf sheaths. The tissue invaded by $S$. notomm shrivels and the lesions become brittle-dry. Transpiration rate and photosynthesis are reduced almost immediately after infection. Retention of assimilates has been reported, probably due to a destruction of the living phloem which hampers the translocation of assimilates. Water transport to leaf parts apical to the lesion does not seem to be reduced.

Combined effects of rust and Septoria nodorum

Combined effects of rust and $S$. nodomm have been reported by van der wal et al., 1970; Van der Wal and Zadoks, 1971, and Van der Wal and Cowan, 1974. Previous rust infection enhances the deletereous effects of $s$. nodorm. Rust infection on the leaves enhances S. nodorm infection on the heads. Rust sporulation ceases soon after $S$. nodorum infection and the formation of teleutosori is stimulated. The combined action of these pathogens may be fatal to the plant: leaf area is destroyed, few or no assimilates are transported to the roots, and the plant just dies. 


\section{'Stress', a systems approach}

Little can be said about the quantitative aspects of disease on wheat, when 'amounts' of 'injurious agents' are not considered in relation to the magnitude and the rate of change they cause in the plant. In addition, the 'state' of the plant itself affects its response to injurious agents. The state of the plant is largely deternined by its enviroment, especially in the way in which environment affects development, growth and transpiration in the course of time. The introduction of various soil-water potentials and their effect on wheat in health and disease is an example of such a determination (Van der Wal et a1., 1975; Cowan and Van der Wa1, 1975).

\section{Systems approach}

In the vernacular of systems analysis, the plant with its reactions to changes in the environment may be considered as a highly controlled but poorly understood cybernetic mechanism, a 'system'. The nature of the control mechanisms is neither known nor relevant here. Only the pattern of responses to changes in the environment is discussed (Ashby, 1971). In order to describe the wheat plant as a system, system borders have to be defined. The numerical values of environmental changes have to be described from the point of view of the system. A prerequisite is a logical positioning of the sensors taking into account the system borders. For the present purpose, the system borders are there where practically no effect of the presence of the organism can be demonstrated. For example, the system border for temperature is a few $\mathrm{cm}$ from the plant surface, because a gradient of temperature due to the presence of the plant can no longer be measured at that distance with the available equipment.

For each environmental factor, e.g. radiation, humidity, or temperature, two properties are of importance, viz. the level of the factor and the amplitude of the variations around that level, the 'noise'. A plant grown at a 'constant' temperature with a noise of \pm 0.5 degrees is considered to 
be different from a plant grown at the same average temperature but with a noise of \pm 5 degrees.

\section{Stress}

In relation to the reaction of the plant to changes in the enviroment, stress is often mentioned. The concept 'stress' refers to the state of the organism during the process of responding to sudden or extreme changes in the environment. The concept has been defined by Selye, a medical physiologist, for the set of reactions provoked by an 'injurious' stimulus or stressor. In agronomy, the discussions about stress in relation to drought, frost, and heat resistance have a long history (Gates, 1964; Levitt, 1963).

The relaxation time of the system, the time interval from the beginning of the stressor action until the arrival of a new steady state of the system, is a characteristic of the stressed state, as is the shape of the curve depicting response versus time. A rapid and smooth transition from the original to the equilibrium state after stressor action indicates a 'well adapted' syster. Original level, rate of change, and duration of change of an environmental factor are of importance to the magnitude of the stress in the system as shown by its response (Fig. 3), e.g. a change from 20 degrees

Fig. 3. Diagram of a relation between stressor and response in the course of time

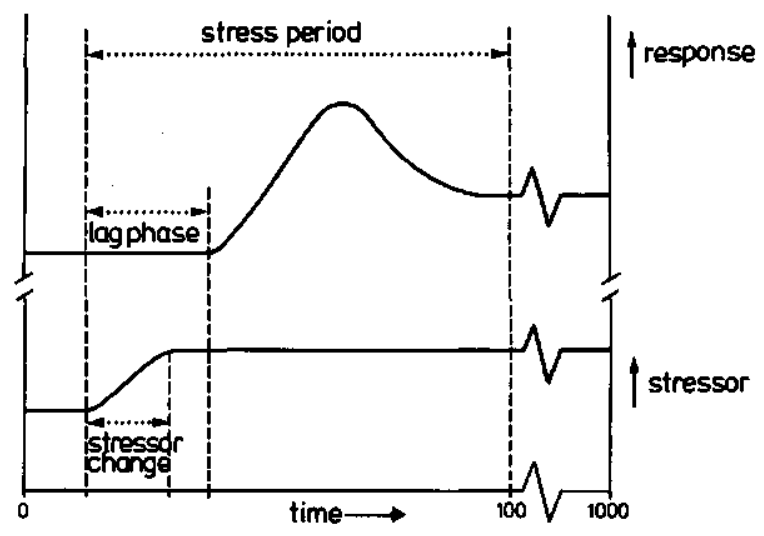

Fig. 3. Schematische voorstelling van een verband tussen stressor en responsie in de loop van de tijd. 
to 40 in 5 minutes may cause another response from that from 5 to 25 degrees in 20 minutes. In an experiment reported in the appendix, Van der Wal et a1. (1975) made three obviously different organisms out of one wheat cultivar just by changing soil-water potential. After 3 weeks one set was subjected to a higher water potential, another set to a lower one, while a third set remained at the original level. In other words, a stressor was applied without leading to permanent stress of the plants as evidenced by the fact that at all three levels of soil-water potential a new state of equilibrium was reached. When in a later phase of the experiment rust here seen as part of the system, a subsystem, was activated, the aegricorpora at two levels of soil-water potential came in stress for a longer time resulting in a breakdown, whereas the aegricorpus at one level of soil-water potential did not remain in stress because it adapted itself to a new level of equilibrium. It is evident that, when stressors become too strong (very rapid and large changes), the system cannot respond adequately, 'it runs out of control', the plant dies.

\section{Quantifying stress}

Stress is the state of the plant or aegricorpus during sudden or extreme changes in the enviromment. A minimum of stress is induced, when the relaxation time is short, the lag phase is long, and the response curve is smooth (Fig. 3). A maximum of stress occurs when an equilibrium state is not reached; in that case the relaxation time is infinite and the lag phase is usually short. The pattern of the stressor and that of the response can be compared in graphs (Fig. 3). Response can be expressed in the dimension of 'acceleration' $\left(t^{-2}\right)$, or more precisely an acceleration during $x$ minutes with a lag phase of $y$ minutes. To determine operationally whether a new equilibrium is reached or not, one may use a time step of a next higher order than the one used for the response time; e.g., if the response time is of the order of seconds, the new equilibrium should be visible during a period of minutes. 


\section{Evaluation}

The motive of the author to embark upon the research reported here was the need to develop new concepts to approach the problem of crop losses, and eventually the problem of their prevention by means of disease control and plant breeding. The introduction of ecophysiology as an approach, explained above, was the first result. An ecophysiological treatment of processes like growth and development of plants in health and disease necessitates adjustments of current thoughts on experimental techniques and on organization in research (Van der WaI and Cowan, 1974).

In order to measure plant or aegricorpus responses concurrently with environmental factors in climate chamber and field experiments during periods of months, a great variety of instruments had to be bought, modified, or devised. The climate chamber had to be adjusted to allow for high light intensities with a view to growing wheat under conditions approximating those of early summer in the Netherlands; the yield of the spring wheat 'Kolibri' was c. $0.5 \mathrm{~kg} \cdot \mathrm{m}^{-2}$, which is nearly equivalent to the average field production of the country. Regulations for the prevention and control of contamination by aphids and mildew without any use of chemicals were issued after detailed experimentation (Van der Wal, unpubl.). Several instruments have been developed, usually with the help of others; this has led to two publications (Schurer and Van der Wal, 1972; Tegelaar and Van der Wa1, 1974). These efforts resulted in the experimental designs described in the appendix. Field experiments, conducted in the same period as the climate chamber experiments reported here, will be published later. It is felt that the techniques to record growth of pathogens are still inadequate.

The results reported in the appendix show that the 'state' of the plant at the time of infection is a major determinant of the plant's future behaviour, which plant breeders and pathologists can express in terms of resistance and tolerance. The conceptual franework presented above may contribute to a future revision of crop husbandry and crop protection practices. 


\section{Samenvatting}

Een ecophysiologische benadering van 'schade' geïllustreerd aan het systeem tarwe, bruine roest en kafjesbruin

Dit proefschrift is opgebouwd uit zes hoofdstukken, alsmede een appendix bestaande uit vier artikelen. Het eerste hoofdstuk fungeert als titelverklaring. Daar wordt ingegaan op de relatie tussen de plantefysiologie en de ecologie; voorts wordt de bijdrage van de fytopathologie geschetst in het gebied waar de eerste twee takken van wetenschap elkaar raken. De term 'aegricorpus' wordt nader verklaard. Het doel van het onderzoek wordt vervolgens omschreven als het leveren van een bijdrage tot het voorkomen van schade met behulp van ecophysiologische beschouwingswijzen.

Dan volgt een overzicht van de gangbare methoden on studies over 'schade' te verrichten, waaronder veldproeven en veldinspectie. De plaats van de ecophysiologische benadering wordt aangegeven.

Het derde hoofdstuk handelt over de ontwikkeling, groei en transpiratie van 'gezonde' tarwe. Het al dan niet bestaan van 'kritieke perioden' in de groei wordt besproken.

De invloed van de bruine roest ( $P$. reconcitta Rob. ex Desm. f.sp. triticina Eriks.) en de verwekker van kafjesbruin (Septoria nodorum Berk.) op de tarwe wordt in het vierde hoofdstuk besproken. Aantastingen door roest verhogen de transpiratie van het blad, doen de photosynthese afnemen, en doen de stroom van assimilaten vamit het aangetaste blad grotendeels ophouden. Dit kan o.a. slechte wortelgroei, en het afstoten van korrels tot gevolg hebben. Septoria infecties vernietigen het weefsel in de gekoloniseerde delen, verlagen de transpiratie, en belemmeren de afvoer van assimilaten. De gevolgen hiervan voor de tarweplant worden besproken. De grootte van de gemeten effecten hangt niet alleen af van het pathogeen en zijn hoeveelheid, maar ook van de toestand waarin de plant zich bevindt. 
Als een methode om meer kwantitatief de responsie van de zieke plant op haar milieu te benaderen wordt de systeemanalyse genoemd.

'Stress' wordt kwantitatief gedefinieerd; de meetbaarheid van 'stress' wordt besproken.

De evaluatie tenslotte handelt over de stand van zaken bij de aanvang van dit onderzoek, de methodiek van het onderzoek en het bereikte resultaat. Voor details wordt verwezen naar de appendix. De toestand van de plant ten tijde van de infectie is een belangrijke determinant van zijn toekomstig gedrag, dat door veredelaars en planteziektenkundigen uitgedrukt kan worden in termen van resistentie en tolerantie. Het geschetste begrippenkader zou kunnen bijdragen tot een herziening van de huidige praktijk in plantenteelt en gewasbescherming. 


\section{References}

Ashby, W.R., 1971. An introduction to cybernetics. Chapman \& Hall Ltd and University paperbacks, pp 295.

Barrs, H.D., 1971. Cyclic variations in stomatal aperture, transpiration, and leaf water potential under constant environmental conditions. A. Rev. P1. Physio1. 22: 223-236.

Boonstra, A.E.H.R., 1929. Invloed van de verschillende assimileerende delen op de korrelproductie bij wilhelmina tarwe. Meded. LandbHooges ch. Wageningen, 33: 3-21.

Brönnimann, A., 1968. Zur Kenntnis von Septoria nodorum Berk,, dem Erreger der Spelzenbräune und einer Blattdürre des Weizens. Phytopath. Z. 61: 101-146.

Brönnimann, A., Sally, B.K. \& Sharp, E.L., 1972. Investigations on Septoria nodorum in spring wheat in Montana. P1. Dis. Reptr: 188-191.

Brouwer, R.,. 1967. Beziehungen zwischen Sprosz- und Wurzelwachstum. Angew. Bot. 41: 244-254.

Brouwer, R. \& Wit, C.T. de, 1968. A simulation model of plant growth with special attention to root growth and $i$ ts consequences. Proc. 15th Easter Schoo1 Agric. Sci.: 224-242.

Brouwer, R., 1973. Plant physiology and ecology. Acta bot. neer1. 22: $260-261$.

Bunting, A.H. \& Drennan, D.S.H., 1966. Some aspects of the morphology and physiology of cereals in the vegetative phase. In: Milthorpe, F.L., and Ivins, J.D. (ed.), The Growth of Cereals and Grasses. London Butterworths, pp 358.

Bushnell, W.R. \& Rowe1l, J.B., 1968. Premature death of adult rusted wheat plants in relation to carbon dioxide evolution by root systems. Phy topathology 58: 651-658.

Buttrose, M.S. \& May, L.H., 1965. Seasonal variation in estimates of cereal ear photosynthesis. Ann. Bot. N.S. 29: 79-81.

Caldwe11, R.M., 1968. Breeding for general and/or specific plant disease resistance. Proc. 3rd. Int. Wheat Genetics Symp., Canberra: 263-272.

Carr, D.J. \& Wardlaw, I.F., 1965. The supply of photosynthetic assimilates to the grain from the flag leaf and ear of wheat. Austr. J. biol. Sci. 18: 711-719.

Clifford, B.C., 1972. The histology of race non-specific resistance to Puccinia hordeì Otth. in barley. Proc. Eur. and Mediterr. Cereal Rust Conf., Prague: 75-79.

Colinvaux, P.A., 1973. Introduction to ecology. Wiley \& Sons Inc. New York, London, pp 621. 
Cowan, M.C. \& Wa1, A.F. van der, 1975. An ecophysiological approach to crop losses, exemplified in the systems wheat, leaf rust and glume blotch IV. Water flow and leaf-water potential of uninfected wheat plants and plants infected with $P$. recondita f.sp. triticina. Neth. J. P1. Path. 81: 49-57.

Dobben, W.H. van, 1962. Influence of temperature and light conditions on dry matter distribution, development rate and yield in arable crops. Neth. J. agric. Sci. 10: 377-389.

Donald, C.M., 1968. The breeding of crop ideotypes. Euphytica 17: 385-403.

Doodson, J.K., Manners, J.C. \& Myers, A., 1964 a. The distribution pattern of 14 Carbon assimilated by the third leaf of wheat. J. exp. Bot. 15: 96-103.

Doodson, J.K., Manners, J.C. \& Myers, A., 1964 b. Some effects of Yellow Rust (Puccinia striiformis) on 14 Carbon assimilation and translocation in wheat. J. exp. Bot. 16: 304-317.

Doodson, J.K., Manners, J.C. \& Myers, A., 1964 c. Some effects of Yellow Rust (Puccinia striiformis) on the growth and yield of a spring wheat. Ann. Bot. N.S. 28: 458-472.

FA0, 1971. Manual on the evalution and prevention of losses by pests, disease and weeds. Ed. L. Chiarappa. FAO/C.A.B., Alden Press, Oxford.

F1orell, C. \& Rufe1t, H., 1960. Transpiration of wheat plants cultivated under different enviromment conditions. Physiol. P1ant. 13: 482-486.

Foltyn, J., 1972. The determination of the tolerance of wheat to attack by rusts in the breeding nursery. Proc. Eur. Mediterr. Cereal Rust Conf., Prague: 109-111.

Friend, D.J.C., 1966. The effects of light and temperature on the growth of cereals. In: Milthorpe, F.L., and Ivins, J.D. (ed.), The growth of Cereals and Grasses. Butterworths, London, pp 358.

Garrett, S.D., 1972. On learning to become a plant pathologist. A. Rev. Phytopath. 10:1-7.

Gates, G.T., 1964. The effect of water stress on plant growth. $\mathrm{J}$. Aust. Inst. agric. Sci. 30: 3-22.

James, W.C., 1969. A survey of foliar diseases of spring barley in England and Wales in 1967. Ann, app1. Biol. 63: 253-263.

James, W.C., 1974. Assessment of plant diseases and losses. A. Rev. Phytopath. 12: 27-48.

Johnson, L.B., Brannaman, B.L. \& Zscheile, F.R., 1968. Protein and enzyme changes in wheat leaves following infection with Puccinia recondita. Phytopathology 58: 578-583.

Jong, G.J. de, 1970. Behandeling van wintertarwe met fungiciden. Stiks tof 6: 189-191.

Justesen, S.H. \& Tammes, P.M.L., 1960. Studies on yield losses I. The self-limiting effect of injurious or competitive organisms on crop yield. T. P1.Ziekten 66: 281-287.

Khan, M.A. \& Tsunoda, S., 1970. Differences in leaf photosynthesis and leaf transpiration rates amoung six commercial wheat varieties of West Pakistan. Jap. J. Breed. 20: 344-350.

$\mathrm{Kl}$ einendorst, A. \& Brouwer, R., 1970. The effect of temperature of the root medium and of the growing point of the shoot on growth, water content and sugar content of maize leaves. Neth. J. agric. Sci. 18: 140-148.

Kriedemann, P., 1966. The photosynthetic activity of the wheat ear. Ann. Bot., N.S. 30: 350-363. 
Kuiper, P.J.C., 1961. The effect of environmental factors on the transpiration of leaves, with special reference to stomatal light response. Meded. LandbHoogesch. 61 (7), 49 pp.

Large, E.C., 1966. Measuring plant disease. A. Rev. Phytopath. 4: 9-28.

Levitt, J., 1963. Hardiness and the survival of extremes: a uniform system of measuring resistance and its two components. In: Evans, L.T. (ed.): Environmental Control of Plant growth: 351-365 Acad. Press, New York, London.

LeClerg, E.L., 1970. Field experiments for assessment of crop losses. FAO Manual Crop Loss Assessment methods, 2.1: 1-15, Rome.

Loegering, W.Q., 1972. Specificity in plant disease.

In: Biology of rust resistance in Forest Trees. Bingham R.T., et al. (eds.) Proc. NATO-IUFRo Adv. Study Inst., U.S. Dep. Agr., Forest Service, Misc. Pub1. 1221, $621 \mathrm{pp.}$

Loomis, R.S., Williams, W.A., \& Hall, A.E., 1971. Agricultural productivity. A. Rev. P1. Physiol. 22: 431-468.

Lupton, F.G.H, 1968 a. The analys is of grain yield of wheat in terms of photosynthetic ability and efficiency of translocation. Ann. appl. Biol, 61: 109-119.

Lupton, F.G.H, 1968 b. Physiological parameters of yield in wheat. Fifth Congr. Eur. Ass. Res. P1. Breeding, Milan, Sept. 30, Oct. 2: 457-464.

Martin, N.E. \& Hendrix, J.W., 1974. Anatomical and physiological responses of Baart wheat roots affected by stripe rust. Techn. Bul1. 77 Wash. agric. Exp. Stn: pp 17.

Oort, A.J.P., 1963. A gene-for-gene relationship in the TriticumUstulago system, and some remarks on host-pathogen combinations in general. Neth. J. P1. Path. 69: 104-109.

Patrick, J.W.,.1972. Distribution of assinilate during stem elongation in wheat. Aust. J. biol. Sci. 25: 455-467.

Percival, J., 1921. The wheat plant; a monograph. Duckworth \& Co, London, pp 463.

Pfeffer, W., 1897. Pflanzenphysiologie, Engelmann Verlag, Leipzig, Vo1 I: 7 .

Puckridge, D.W., 1968. Photosynthesis of wheat under field conditions I. The interaction of photosynthetic organs. Aust. J. agric. Res. 19: 711-719.

Puckridge, D.W., 1972. Photosynthesis of wheat under field conditions $V$. The effect of solar elevation on the distribution of photosynthetic activity within the crop canopy. Aust. J. agric. Res, 23: 397-404.

Salter, P.J. \& Goode, J.E., 1967. Crop responses to water at different stages of growth. Res. Rev. 2, C.A.B., 246 pp.

Samborski, D.J. \& Shaw, M., 1956. The physiology of host-parasite relations II. The effect of Puccinia graminis tritici Eriks. and Henn. on the respiration of first leaf of resistant and susceptible species of wheat. Can. J. Bot. 34: 601-619.

Scharen, A.L. \& Taylor, J.M., 1968. $\mathrm{CO}_{2}$ assimilation and yield of Little Club wheat infected by Septoria nodorum. Phytopathology 58: $447-451$.

Scharen, A.L. \& Krupinsky, J.M., 1969. Effects of Septoria nodorum infection on $\mathrm{CO}_{2}$ absorption and yield of wheat. Phytopathology 59: 1298-1301.

Schurer, K. \& WaI, A.F. van der, 1972. An electronic leaf wetness recorder. Neth. J.P1. Path. 78: 29-32.

Schuurman, J.J. \& Knot, L., 1970. Vergelijking van de wortelontwikkeling van drie grassoorten en zomertarwe. Vers1. Landbouwk. Onderz. 745, Pudoc, Wageningen, Pp 15. 
Shaw, M., 1964. The physiology and host-parasite relations of the rust. A.Rev. Phytopath. 2: 259-294.

Shaw, M. \& Samborski, D.J., 1957. The physiology of host-parasite relations III. The pattern of respiration in rusted and mildewed cereal leaves. Can. J. Bot. 35: 389-407.

Shipton, W.A., 1968. The effect of Septoria diseases on wheat. Aust. J. exp. Agric. Anim. Husb. 8: 89-93.

Shipton, W.A., Boyd, W.R.J., Rosielle, A.A. \& Shearer, B.L., 1971. The common Septoria diseases in wheat. Bot. Rev, 37: 231-262.

slangen, J.H.G. 1971. Intermitterende voeding bij tarwe. Vers 1. Landbouwk. Onderz. 765, Pudoc, Wageningen, pp 130.

slatyer, R.0., 1957. The influence of progressive increase in total soil moisture stress on transpiration, growth and internal water relationships. Aust. J. biol. Sci. 10: 320-336.

Slavik, B., 1966. Response of grasses and cereals to water. In: Milthorpe, F.L., and Ivins, J.D. (ed.), The Growth of Cereals and Grasses. Butterworths, London, pp 358.

Stoy, V., 1963. The translocation of $C_{14}$-labelled photosynthetic products from the leaf to the ear in wheat. Physiol. Plant. 16: $851-866$.

Strebeyko, P., Wislocka, M. \& Krzywacka, T., 1963. Dynamics of growth and development in spring wheat. Physiol. P1ant. 16: $359-367$.

Tammes, P.M.L., 1961. Studies of yield losses II. Injury as a limiting factor of yield. T. P1.-ziekten 67: 257-263.

Tegelaar, P. \& Wal, A.F. van der, 1974. An ecophysiological approach to crop losses, exemplified in the system what, leaf rust and glume blotch. I. A simple and accurate balance for the continuous measuring and recording of (evapo-) transpiration of plants in indoor experiments. Neth. J. P1. Path. 80: 77-84.

Virgin, H.I., 1956. Light-induced stomatal movements in wheat leaves recorded as transpiration. Physiol. Plant. 9: 280-303.

Wal, A.F. van der, Shearer, B.L. \& Zadoks, J.C. 1970. Interaction between Puccinia recondita and Septoria nodorum on wheat, and its effects on yield. Neth. J. P1. Path. 76: 29-32.

Wal, A.F. van der \& Zadoks, J.C., 1971. Interaction of fungal pathogens and its effect on crop losses in wheat. Proc. 2nd. Int. Symp. Plant Path., New Delhi, Jan. 27-Febr. 3. (in press).

Wa1, A.F. van der \& Cowan, M.C., 1974. An ecophysiological approach to crop losses, exemplified in the system wheat, leaf rust and glume blotch II. Development, growth, and transpiration of uninfected plants and plants infected with Puccinia recondita f.sp. triticina and/or Septoria nodorum in a climate chamber experiment. Neth. J. P1. Path. 80: 192-2I4.

Wa1, A.F. van der, Smeitink, Hanneke \& Maan, G.C., 1975. An ecophysiological approach to crop losses, exemplified in the system wheat, leaf rust and glume blotch III. Effects of soil-water potential on development, growth, transpiration, symptoms, and spore production of leaf rust infected wheat. Neth. J. P1. Path. 81: 1-13.

Wellington, P.S., 1966. Germination and seedling emergence. In: Milthorpe, F.L, and Ivins, J.D. (ed.), The Growth of Cereals and Grasses, Butterworths, London, pp 358.

Wit, C.T. de \& Brouwer, R., 1968. ther ein dynamisches Mode11 des vegetativen Wachstums von Pflanzenbeständen. Angew. Bot. 42: $1-12$.

Woodruff, D.R., 1969. Studies on presowing drought hardening of wheat. Aust. J. agric. Res. 20: 13-24. 
Yarwood, C.E., 1953. Heat of respiration of injured and diseased leaves. Phytopathology 43: 675-681.

Yarwood, C.E. \& Cohen, M., 1951. Hypertrophy from the uredial stage of bean rust. Bot. Gaz. 112: 294-300.

Yirgou, D. \& Caldwel1, R.M., 1968. Stomatal penetration of wheat seedlings by stem and leaf rusts in relation to effects of carbon dioxide, light, and stomatal aperture, Phytopathology 58: 500-507.

Zadoks, J.C., 1972. Modern concepts of disease resistance in cerea1s. In Lupton, F.G.H., et al. (eds.) The way ahead in plant breeding. Proc. 6th. Eucarpia Congr., Cambridge, 1971: 89-98. 


\section{Curriculum vitae}

Antonius Franciscus van der wal werd geboren op 18 augustus 1943 te Arnhem. In 1962 behaalde hij het einddiploma gymnasium- $\beta$ aan het Thomas à Kempis Lyceun te 2 wolle. Van 1962 tot 1970 studeerde hij aan de Landbouwhogeschool te Wageningen in de richting Planteziektenkunde; het ingenieursexamen omvatte de vakken: de fytopathologie, de erfelijkheidsleer, de wiskundige statistiek, de plantenveredeling en de houtteelt. De praktijktijd werd doorgebracht deels in de N.O.P. op Geertsema's Veredelingsbedrijf en deels op het Plant Breeding Institute te Cambridge, Engeland. Vanaf februari 1970 was hij als promotie-assistent werkzaam op het Laboratorium voor Fytopathologie. Van augustus 1972 tot februari 1975 is hij als wetenschappelijk ambtenaar verbonden aan hetzelfde laboratoriun, mede belast met onderwijs in de genetisch/ecologische aspecten van resistentie. Hij was lid van de Werkgroep ethiek-wetenschappelijk onderwijs van de Academische Raad (19691973) en secretaris van de faculteitscommissie Logica, kennis- en wetenschapsleer (1970). 
Appendix 


\title{
An ecophysiological approach to crop losses exemplified in the system wheat, leaf rust and glume blotch
}

\section{A simple and accurate balance for the continuous measuring and recording of (evapo-)transpiration of plants in indoor experiments}

\author{
P. TEGELAAR ${ }^{1}$ and A. F. VAN DER WAL ${ }^{2}$ \\ ${ }^{1}$ IWECO-TNO, Delft \\ 2 Laboratory of Phytopathology, Agricultural University, Wageningen
}

Accepted 10 January 1974

\begin{abstract}
A cheap and convenient balance for measuring and recording the transpiration rate of plants placed in pots, buckets, etc. is described. The essential mechanical part of the balance is a cross spring pivot. A change in weight on the balance arm causes an angular displacement of the arm with regard to the carrying structure. Torsion forces in the cross spring hinge compensate the change in weight, and a new stable equilibrium can be reached in any position of the balance arm within the limits of its movement $\left(2^{\circ} 40^{\prime}\right)$. The position of the balance arm is transformed into millivolts DC by using a displacement transducer. The instrument can be loaded up to $25 \mathrm{~kg}$ (pots, soil, water, counterweights). The range of the balance is 500 grams, and the resolution of the output is better than 1 gram $(1 \mathrm{ml})$. Other loads, ranges and resolutions can be realised by altering the characteristics of the cross spring pivot and the displacement transducer.
\end{abstract}

\section{Introduction}

Present research on the relation between yield loss in wheat and symptoms caused by pathogenic fungi requires accurate information on the (evapo-) transpiration rate of infected and non-infected plants over the full growth period of the plant, for the purpose of calculating stomatal resistances and energy budgets. A relatively cheap and covenient method of collecting this information in indoor experiments with pot plants was necessary. The payload of the instrument to be designed should be $25 \mathrm{~kg}$, in view of the weights of buckets with soil and water. The resolution should be better than $1 \mathrm{~g}$.

During the experiment, the position of the plants should be changed as little as possible for the transpiration measurement because of mutual interference with neighbour plants.

Loss of weight of plants in a container (pot, tube, bucket, etc.) was chosen as the basis of the measurement. As with lysimeters, corrections for the evaporation of the soil (or nutrient solution) can be made by comparison with plant free controls, and the increase in plant weight by $\mathrm{CO}_{2}$ and/or water uptake can be taken into account.

These requirements were translated in mechanical terms as to designing a balance with a limited displacement of the arms, and with an output suitable to be recorded by a millivolt recorder. 
Fig. 1. General view of the balance; $\mathrm{CC}=$ Part of the carrying structure; $\mathrm{CSP}=$ Cross spring pivot; $\mathrm{CW}=$ Counterweight $; \mathrm{DT}=$ Displacement transducer; PL $=$ Payload; MA $=$ Movable arm; $\mathrm{S}=$ Stop with screw.

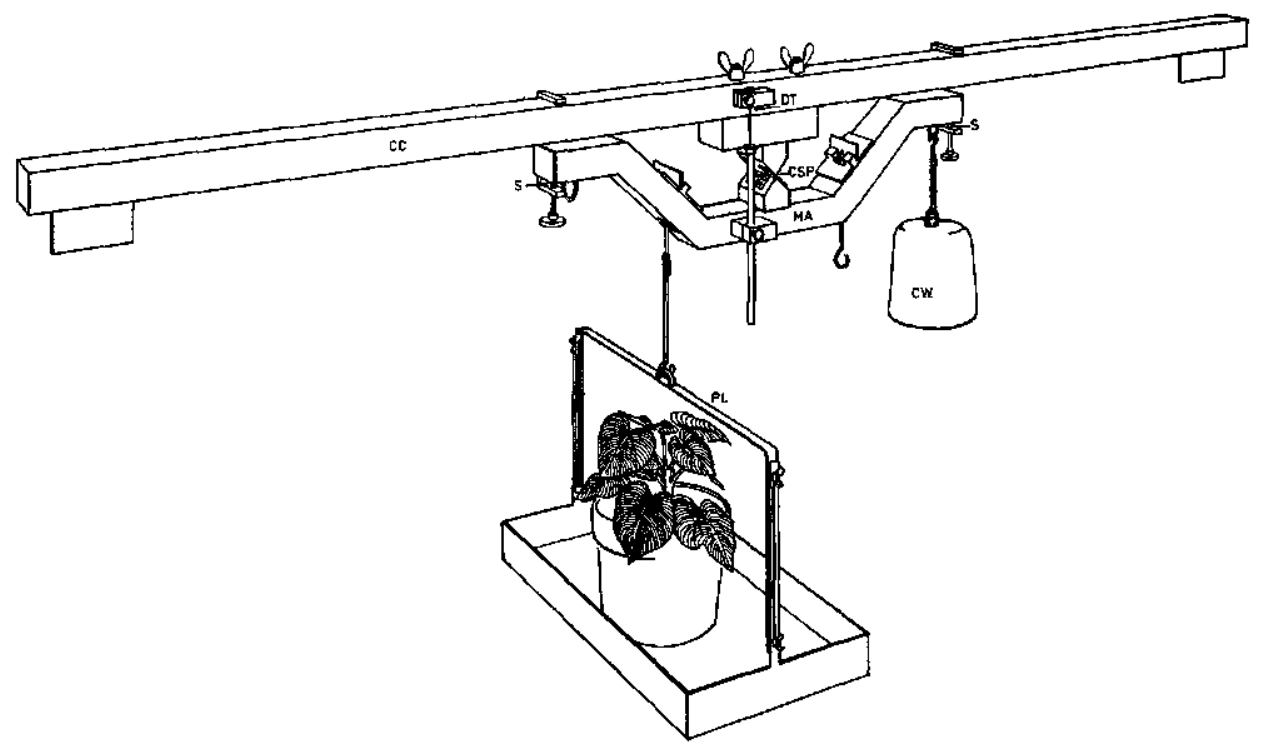

Fig. 1. Overzichtsbeeld van de balans; $C C=$ deel van de draagconstructie; $C S P=k$ krusveerscharnier; $C W=$ contragewicht $; D T=$ displacement transducer $P L=$ nuttige belasting; $M A=$ beweegbare arm; $S=$ aanslag met schroef.

\section{The mechanical part of the balance}

$A$ cross spring pivot balance (Fig. 1). The movable arm (MA) is fastened to the carrying structure with four leaf springs placed cross-wise at an angle of $90^{\circ}$ (Fig. 1 and 2). The payload of the object under study can be compensated by a suitable counterweight at the opposite end of the balance arm.

Changes in weight of the object or the counterweights cause a small angular displacement of the balance arm. Within the designed limits of the angular displacement, any position of the arm can be stable as a result of the equilibrium between the bending forces in the leafsprings and the momenta on the arm. In this design a cross spring pivot has a number of advantages. It needs no maintainance, no wear will occur, and under normal static loading conditions no fatigue is to be expected.

Fig. 2. Constructional details of the balance. A: Front view and proportions of the balance. B: Diagram and proportions of the displacement transducer. $\mathrm{C}$ : General view and proportions of the cross spring pivot.

Fig. 2. Constructiedetails van de balans. A: Vooraanzicht en afmetingen van de balans. B: Schema en afmetingen van de 'displacement transducer'. C: Overzichtsbeeld en afmetingen van het kruisveerscharnier. 


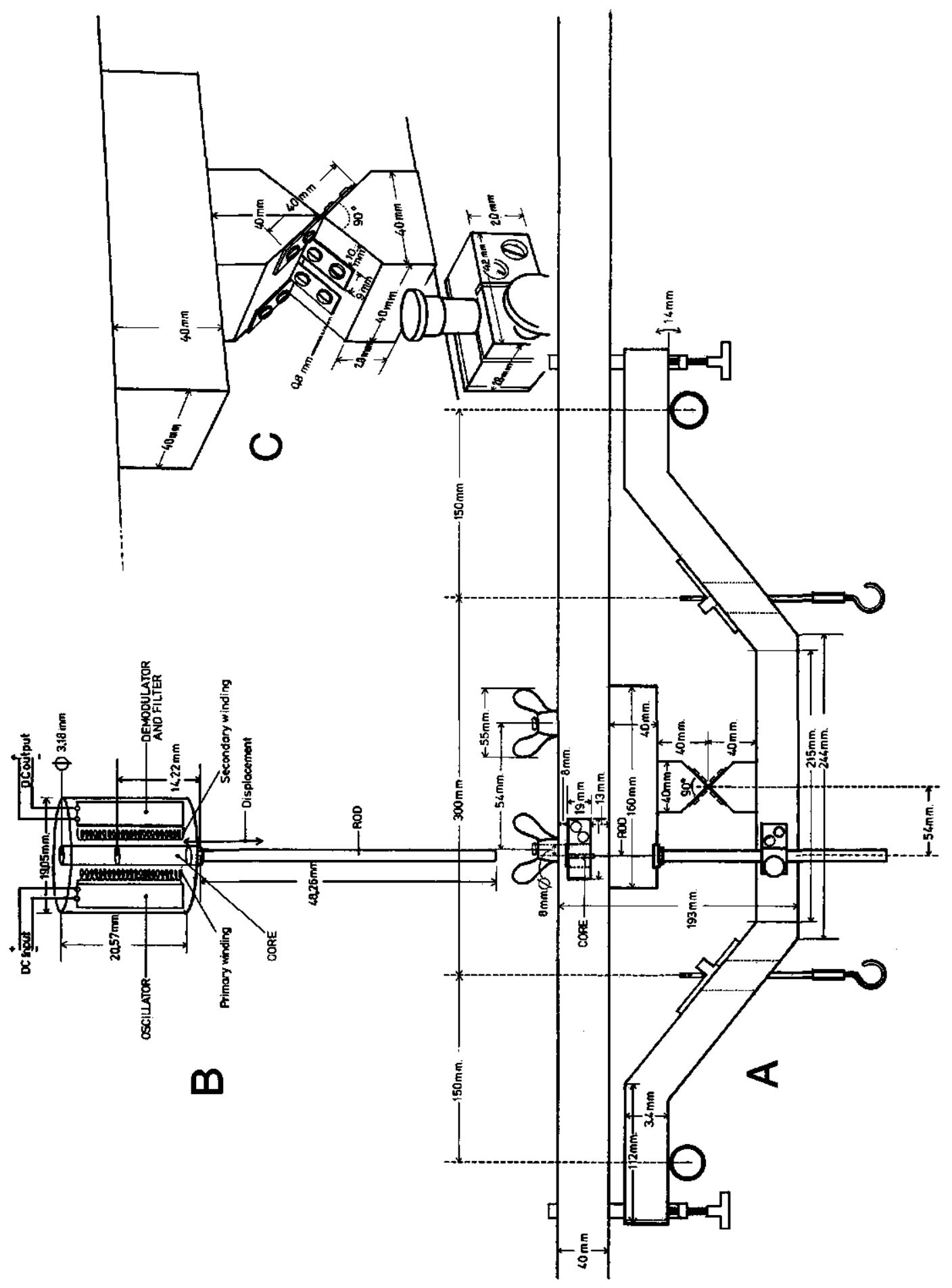


For small angular displacements Hooke's law applies, viz. that the deformation of a leaf spring is proportional to the deforming force. In the balance described the maximum angular displacement from the horizontal position is for $1^{\circ} 20^{\prime}$, or in total $2^{\circ} 40^{\prime}$. This comes to a $14 \mathrm{~mm}$ stroke at the end of the arm, $300 \mathrm{~mm}$ from the axis of rotation. Stops at the ends of the arm limit its movement. By means of screws through the stops the arm can be blocked to enable major changes in the load to be made, such as removing counterweights or containers with soil. This blocking is necessary to avoid distortion of the cross spring pivot.

In designing this type of balance attention had to be payed to the following points:

1. pivot stiffness [ $\left.\mathrm{kg} \mathrm{m} \mathrm{rad}^{-1}\right]$;

2. maximum load of the balance arm [kg];

3. elongation of the leaf springs $[\mathrm{m}]$

The stiffness of a cross spring pivot. The pivot stiffness $(\mathrm{K})$ is defined as the ratio between the torsion momentum (M) acting on the pivot and the resulting angular displacement (Q). For the balance depicted in Fig. 1 and 2, the following values have been determined experimentally:

momentum (M) $\quad: 7.5 \times 10^{-2} \mathrm{~kg} \mathrm{~m}$

angular displacement $(\mathrm{Q}): 2^{\circ} 40^{\prime}(=0,0465 \mathrm{rad})$

pivot stiffness $\mathrm{K}=\frac{\mathrm{M}}{\mathrm{Q}}=: 1.61 \mathrm{~kg} \mathrm{~m} \mathrm{rad}^{-1}$.

From the characteristics of the spring material and the dimensions of the springs the expected pivot stiffness can be calculated, following Wunsch's experimental formula (Ong Bing Jong).

$\mathrm{K}=$ n. $\frac{\mathrm{E} \times \mathrm{I}}{1+8.9 \times 10^{-4}}$

where: $E=$ Young's modulus of elasticity $\left[\mathrm{kg} \mathrm{m}^{-2}\right] ; \mathrm{I}=$ moment of inertia $\left[\mathrm{m}^{4}\right]$; $1=$ free length of the leaf spring $[\mathrm{m}] ; n=$ number of leaf springs.

The stiffness of the cross spring pivot is proportional to the number of springs, the modulus of elasticity of the leaf spring material, and the width of the leaf springs; it is a third power of the thickness of the leaf springs. $K$ is inversely proportional to the free length of the leaf springs.

In the design depicted the leaf spring material was phosphorus bronze with $\mathrm{E}=$ $1.05 \times 10^{10} \mathrm{~kg} \mathrm{~m}^{-2}$, width $0.01 \mathrm{~m}$, thickness $0.8 \times 10^{-3} \mathrm{~m}$, the number of springs was four, the free length $0.01 \mathrm{~m}$. For these rectangular strips $I=1 / 12$. (0.01). (0.8). $10^{-3} \mathrm{~m}^{4}$ (Kronig, 1958). The calculated value of $\mathrm{K}$ is $1.65 \mathrm{~kg} \mathrm{~m} \mathrm{rad}^{-1}$, which is in good agreement with the experimentally determined value.

The maximum load on the balance arm. The maximum load on the arm, including the weight of the arm itself, depends on the tensile strength of the leaf spring material and the area of the horizontal cross section of the strips.

For a $90^{\circ}$ spring pivot, the maximum load Pmax is

$\operatorname{Pmax}=\frac{\sigma_{t} \cdot \frac{n}{2} \cdot F}{0.707}$ 
in which $\sigma_{t}=$ tensile strength $\left[\mathrm{kg} \mathrm{m}^{-2}\right] ; \mathbf{F}=\mathrm{b} . \mathrm{h}\left[\mathrm{m}^{2}\right] ; \mathbf{n}=$ number of leaf springs. In this formula the bending stresses and the stress concentration factor due to the screwholes have been neglected.

The tensile strength of phosphorus bronze is 70 to $105 \times 10^{6} \mathrm{~kg} \mathrm{~m}^{-2}$. For $\mathrm{n}=4$, $\mathrm{F}=8 \times 10^{-6} \mathrm{~m}^{2}$ and $\sigma_{\mathrm{t}}=70 \times 10^{6} \mathrm{~kg} \mathrm{~m}^{-2}$, the maximum load

$$
P \max =\frac{70 \times 10^{6} \cdot \frac{4}{2} \cdot 8 \times 10^{-6}}{0.707}=1585 \mathrm{~kg}
$$

To be sure that the instrument behaves linearly within the elastic range of the leaf spring material, a safety factor 5 is taken into account, so that the maximum load on this cross spring pivot is restricted to $300 \mathrm{~kg}$. The payload used $(25 \mathrm{~kg})$ is far under the calculated maximum.

The elongation of the leaf springs. In the case mentioned, the tensile force in each pair of springs is $P=\frac{1}{2} \sqrt{ } 2.300=210 \mathrm{~kg}$. With a cross section of $2 \times 8 \mathrm{~mm}^{2}$ or $16 \times 10^{-6}$ $\mathrm{m}^{2}$ the strain in the leaf spring material

$\varepsilon=\frac{\sigma}{\mathrm{E}}=\frac{\mathrm{P}}{\mathrm{FE}}=1250.10^{-6}$

For an effective spring length of $0.01 \mathrm{~m}$ the elongation of the springs is then $1.25 \times$ $10^{-5} \mathrm{~m}=12.5 \mu \mathrm{m}$, which is fully negligible in relation to the maximum displacement of the balance arm. In the performance of this balance no measurable deviations will occur because of an elongation of the leaf springs.

\section{The electronic part of the balance}

A displacement transducer was used to convert the position of the balance arm to a proportional electrical output, in this case a $\mathrm{mV} \mathrm{DC}$. Since the displacement of the balance arm is proportional to the forces that caused it, the output is also proportional to these forces.

The Hewlett-Packard displacement transducer, type 7DCDT (Fig. 2b) consists of a differential transformer fed by a $6 \mathrm{~V} \mathrm{DC}$ stabilised power supply unit (HewlettPackard technical data 10/68). The built-in oscillator converts the DC input into an AC supply voltage, which is used to excite the primary winding of the transformer. The axial coreposition determines the voltage induced in the secondary winding. The resulting output, after demodulation and filtering, is a DC voltage proportional to the coreposition with respect to the electrical centre of the transducer.

The body of the transducer, containing oscillator, transformer, demodulator and filter, is mounted on the carrying structure of the balance: the core of the transducer is connected to the movable arm (MA) of the balance (Fig. 1) in such a way that the core can move in the coil of the transformer and that the horizontal position of the arm coincides with the electrical zero point of the transducer.

The end of the balance arm moves + or $-7 \mathrm{~mm}$ at a distance of $300 \mathrm{~mm}$ from the axis of rotation of the cross spring pivot. The displacement transducer, having a full range of + or $-1.27 \mathrm{~mm}$ should therefore be mounted at a distance of approxi- 
mately $54 \mathrm{~mm}$ from the axis of rotation. The output of the 7DCDT transducer is + or $-1.5 \mathrm{~V} \mathrm{DC}$. Adaption of the output to the range of the recorder to be used is not difficult.

\section{The use of the balance}

At the Laboratory of Phytopathology, balances of this type have now been used almost continuously for over a year. Data about transpiration of uninfected plants and plants infected with Puccinia recondita Rob. ex. Desm., Septoria nodorum Berk., separate and in combination, were collected in experiments of the class multiple inputmultiple output (Zadoks, 1972). Experiments of this kind need efficient measurement of individual responses in order to cope with the problem of limited labour supply and the necessity of measuring numerous responses in the same experiment. Results obtained with these balances will be published later. The load has mostly been a

Fig. 3. A typical output of the balance on a strip chart recorder, representing the transpiration of potted wheat plants under constant day conditions, and different but equally constant night condition.

$\uparrow \mathrm{PP}=$ change of the plantposition $(14 \mathrm{~mm})$.

$\downarrow \mathrm{CW}=$ change of the counterweight position.

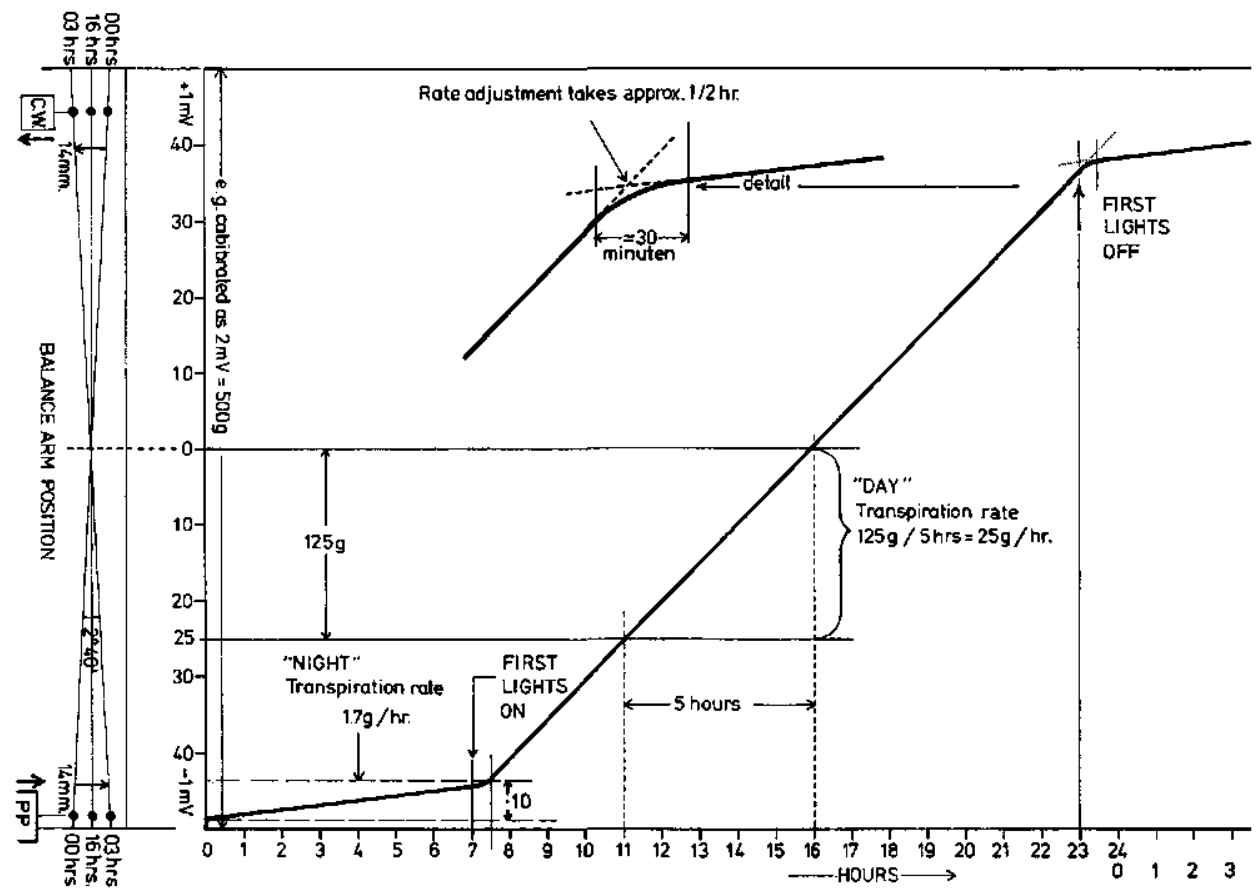

Fig. 3. Een karakteristieke uitkomst verkregen met de balans op een schrijver met papierstrook, voorstellende de transpiratie van potplanten van tarwe onder constante dag- en andere, maar eveneens constante nacht-omstandigheden.

$\uparrow P P=$ verandering van de positie van de plant $(14 \mathrm{~mm})$.

$\downarrow C W=$ verandering van de positie van het contragewicht. 
bucket with soil, water and plants, weighing about $12 \mathrm{~kg}$. This load was suspended at a distance of $150 \mathrm{~mm}$ from the axis of rotation. At the other end of the arm, $300 \mathrm{~mm}$ from the axis, a counterweight of lead of about $6 \mathrm{~kg}$ was attached. The range of the balance was about 500 grams. Calibrations were carried out with stamped analytical weights.

When the counterweight end of the arm just touched its lower stop, and approximately $500 \mathrm{ml}$ of water was added to the bucket with plants, the arm moved over $2^{\circ}$ $40^{\prime}$ so that the end of the arm with the bucket just touched its lower stop. The bucket with plants lost weight by evaporation and transpiration and the weight lost weight by evaporation and transpiration and the weight loss was recorded until $500 \mathrm{ml}$ of water had gone. Then the balance was again arrested by the lower stop of the arm's counterweight end, and additional watering or additional taring were necessary to get the balance back in range.

Fig. 3 shows a record of weight loss by wheat plants in a bucket wtith soil during a 24-hour cycle in a growth chamber. Because of the reaction of the stomata the transpiration rate increased almost by a factor 10 after the lights were switched on. The time needed by the plants to adapt from darkness to light transpiration rate to the light period rate was 20 to 30 minutes. It took about another 30 minutes to adapt to the darkness transpiration rate after the lights were switched off. 'Twilight', the period from the ignition of the first lamp till that of the last one lasts half an hour. At the end of the light period the lamps are also switched off in half an hour. The transpiration rate can be derived directly from a record as shown in Fig. 3, if no corrections (for e.g. soil evaporation) are needed.

\section{Samenvatting}

Een ecofysiologische benadering van 'schade', geillustreerd aan het systeem tarwe, bruine roest en kafjesbruin.

I. Een eenvoudige en nauwkeurige balans voor de continue meting en registratie van (evapo-) transpiratie van planten in binnen proeven.

Tijdens het onderzoek naar het verband tussen de opbrengstderving en de aantasting door pathogene schimmels bij tarwe, bleek de wenselijkheid om nauwkeurig geïnformeerd te zijn over de transpiratie van zieke en gezonde tarwe.

Transpiratie was slechts één van de te meten responsies in proeven van de klasse 'multiple input- multiple output' (Zadoks, 1972). Proeven van deze klasse maken het gebruik van efficiënte meetmethoden voor iedere responsie afzonderlijk noodzakelijk om te voorkomen dat essentiële responsies niet of slecht worden gemeten wegens tijdgebrek.

Voorts diende de positie van de planten waaraan gemeten werd, zo weinig mogelijk te worden veranderd ten behoeve van de meting, omdat de gemeten transpiratie vergelijkbaar moest zijn met de transpiratie van andere, niet gelijktijdig gemeten planten in de proef.

Een goedkope en weinig arbeid vragende methode wordt beschreven om de transpiratie van planten in kas- en klimaatkamerproeven nauwkeurig te meten en te registreren. Het werktuigkundige deel van het apparaat is een balans met een kruisveer- 
scharnier (Fig. 1 and 2c). Aan de beweegbare arm (MA) worden een pot of een emmer met planten gehangen. Het gewicht daarvan wordt gecompenseerd door een contragewicht (CW) aan het andere einde van de arm. Wordt de arm uit de horizontale stand gebracht door waterverlies van de bak met planten, dan ontstaat een torsiemoment in het kruisveerscharnier, dat tegengesteld werkt aan het moment, dat de balansarm uit de horizontale stand bracht. Wanneer beide momenten met elkaar in evenwicht zijn heeft de balansarm een nieuwe, stabiele positie. De verplaatsing van de arm is gering; de hoekverdraaiing is maximaal $2^{\circ} 40^{\prime}$, gelijk staande met een maximale slag van de arm op $300 \mathrm{~mm}$ afstand van de rotatieas van $14 \mathrm{~mm}$. Het elektronische deel van de balans is een 'displacement transducer' (Fig. 2b). Hiermee wordt de positieverandering van de arm ten opzichte van de draagconstructie gemeten en omgezet in een gelijkspanning. De opnemer bestaat uit een differentiaaltransformator, die aan de draagconstructie is bevestigd, terwijl de beweegbare kern aan de arm is verbonden. De maximale slag van de kern is $2.54 \mathrm{~mm}$. De uitgangsspanning van de opnemer is evenredig met de verplaatsing van de arm, en dus met de gewichtsverandering aan de arm.

Het ijken gebeurt met geijkte analytische gewichten. Een typisch transpiratiepatroon voor planten onder een dag/nachtritme met overigens constante dag- en nachtomstandigheden wordt in Fig. 3 gegeven. De transpiratiesnelheid is hier overdag bijna 10 maal de 'nacht'-snelheid.

\section{Acknowledgments}

The authors are much indebted to Mr O. van Geffen and Mr. G. van Surksum (Instruments Workshop Crop Protection Departments) for the construction of the balance and their interest during its development. Mr C. Burgsteyn (Technical and Physical Engineering Research Service, TFDL) gave valuable advice on the choice of the power supply unit. The continuous interest in the progress of the work shown by Dr J. C. Zadoks has been stimulating. Mr J. H. A. van Beckum's corrections of the English text are gratefully mentioned.

\section{References}

Kronig, R., 1958. Leerboek der natuurkunde. Mechanica van deformeerbare lichamen, p. 100-116. Scheltema \& Holkema NV., Amsterdam. pp. 891.

Ong Bing Jong. De bladveer. Een waardevol constructie-element in de fijnmechanische techniek. $P_{t}$ monografieën reeks $2,14 \mathrm{pp}$. Technische Uitgeverij $\mathrm{H}$. Stam.

Zadoks, J. C., 1972. Methodology of epidemiological research. A. Rev. Phytopath. 10:253-276.

\section{Addresses}

P. Tegelaar, Instituut voor Werktuigkundige Constructies IWECO-TNO, Leeghwaterstraat 5, P.O. Box 29, Delft, the Netherlands.

A. F. van der Wal, -Laboratorium voor Fytopathologie, Landbouwhogeschool, Binnenhaven 9, Wageningen, the Netherlands. 
An ecophysiological approach to crop losses exemplified in the system wheat, leaf rust and glume blotch

\title{
II. Development, growth, and transpiration of uninfected plants and plants infected with Puccinia recondita f.sp. triticina and/or Septoria nodorum in a climate chamber experiment
}

\author{
A. F. VAN DER WAL ${ }^{1}$ and M. C. COWAN ${ }^{2}$ \\ ${ }^{1}$ Laboratory of Phytopathology, Agricultural University, Wageningen \\ ${ }^{2}$ Visiting research worker in grant of a fellowship of the Royal Society, London
}

Accepted 20 May 1974

\begin{abstract}
A climate chamber experiment is reported in which were investigated the growth and transpiration of uninfected wheat plants (C), plants infected with either Puccinia recondita (leaf rust) alone (R), Septoria nodorum (glume blotch) alone (S), or with both pathogens together (I). The rust inoculation was at the $75 \%$ heading stage, and was followed four days later by the glume blotch inoculation; re-infection was prevented. Effects of disease on axial development were not observed. The rate of total dry weight increase of the plants was reduced in $\mathbf{S}$ and $\mathrm{I}$, mainly because of smaller dry weight increase of the heads. Kernel weight and kernel number in I were lower than in C, R, and S. Stems in $\mathbf{S}$ and $\mathbf{I}$ were shorter than those in $\mathbf{C}$ and $\mathbf{R}$, and their weights were lower. Rapid root deterioration was observed in $I$. The transpiration was greater in $R$ than in $C$, in $\mathbf{S}$ smaller. Transpiration in I was initially equal to that in $\mathrm{R}$, but the transpiration rate decreased rapidly after the glume blotch symptoms became visible. The increase in the percentage of infection by rust in I was lower than in $R$, and the sporulation came almost to a stop soon after the appearance of glume blotch flecks. The percentage of infection by glume blotch in I increased faster than in S. Regression equations for growth and transpiration are given.
\end{abstract}

\section{Introduction}

The experiment described here on the effects of infection by pathogens on the yield of plants was performed to gain an understanding of the causes of loss in field crops. Losses are determined at harvest time. An effective method of gaining information about the process that leads to loss is to study the physiology of infected plants from infection to harvest. It is necessary to know the physiological state of the plant at the time of infection, as the response to infection, and consequently the loss, may be related to this physiological state. As the state of the plant at any time is the outcome of its total previous 'history', it is necessary to record the history of the plant from the seedling stage to the time of infection.

Yield and loss are functions of host, pathogen and environment. An infinite number of combinations of cultivars, pathogens and environmental factors can be made. The study of the ecophysiology of crop losses by experiment alone is almost impossible. A feasible approach is the balanced combination of experiment with other techniques 
such as dynamic simulation. Before this 'balanced' combination can be considered, the methodological and organizational aspects of crop loss experiments must be established. Indoor experiments can assist in the development of concepts and methods, and they provide information that is useful in the interpretation of results obtained under field conditions.

This paper discusses the methodology and the organization of experimental research into the ecophysiology of uninfected wheat plants, and wheat plants infected with either Puccinia recondita (Rob. ex Desm.) f.sp. triticina Eriks. (leaf rust) or Septoria nodorum (Berk.) Berk. (glume blotch), or both pathogens together.

\section{Methodology}

\section{General remarks}

A separate treatment of principles, practices and procedures is necessary because of the diversity of the subject. This section considers terminology, choice of experimental and situational factors, choice of responses, selection of sampling techniques, and the choice of statistical methods.

\section{Terminology}

Loss is here defined as the difference in yield between infected and uninfected plants, grown under identical conditions. Loss is measured at harvest. Only the yield of grain is taken into account. Loss is expressed in units of mass. Specific loss is expressed in units of mass per plant, or per unit of area.

Injury is defined as the deviation of the physiology and/or appearance of the treated plant from the corresponding properties of the untreated plant, where the treatment may be either infection by pathogens or change of the environment, under otherwise identical conditions. Pathogens and environment can both act as injurious agents.

Physiology. In this paper, the concept is limited to the processes of development, growth, and transpiration.

Growth is defined here as a change in the state of the plant that can be expressed quantitatively such as length, area, volume, or weight. Growth rate is growth per unit time.

Transpiration and evaporation. In this paper, transpiration is the loss of weight of a plant due to water loss, and evaporation that of the soil due to water loss, expressed in units of mass. Specific transpiration is expressed in units of mass per plant or per unit of area.

Symptoms. The difference in appearance between infected and uninfected plants is determined by many phenomena or factors, some of which are typical of one particular pathogen-host combination, and others are not. Both the typical and the atypical effects of the pathogen(s) on the appearance of the host plant are here indicated by the term symptoms. 
Any factor that can be varied in an experiment is termed a variable. In most experiments, only a few variables are set at more than one level in the experimental design, and these are termed experimental factors. The remaining variables, appearing only at one level, can be referred to as situational factors (Zadoks, 1972). The results of ecophysiological experiments are largely determined by the choice of the levels at which the situational factors are set. Only one spring wheat cultivar, 'Kolibri', and one isolate of each of the pathogens were used. Only one inoculation with each pathogen at one spore density was carried out. The various combinations of diseases can be considered as different levels of one variable, viz. 'disease treatment': $\mathrm{C}=$ uninfected control plant; $R=$ plant with rust alone; $S=$ plant with glume blotch alone; $I=$ plant with both rust and glume blotch.

\section{Responses}

In this single input - multiple output experiment (Zadoks, 1972), a number of output variables, here called 'responses', was assessed. The number of responses monitored was limited owing to restrictions of manpower and equipment. After inoculation, growth and development of the pathogens were described too. The following responses were selected.

Development. Growth stages according to Zadoks et al. (1974). Axial development according to Schoute (1910).

Growth. Dry weights of shoots, roots, leaves (including mycelium in infected leaves), stems with leaf sheaths, heads and kernels; number of kernels; leaf area.

Growth and development of the pathogens. Part of the plant infected and percentage of infection; time of appearance of first uredosori, teleutosori, flecks and pycnidia.

Miscellaneous. Where possible, other responses such as length and width of leaves, length of stems or internodes, number of leaves per axis, and temperature of the plant organs (stems, heads, leaves) were determined.

\section{Experimental design and sampling}

The smallest experimental unit was the single plant with the soil in which it was growing. Six plants together in one bucket formed the measuring unit for the transpiration measurements. Four buckets, containing 24 plants, were subjected to one level of disease treatment. Transpiration measurements were obtained for each of the four buckets belonging to each group. Treatments and replicates were randomized over the experimental area of the growth chamber. The arrangement of the experiment (Fig. 1 and 2) in the climate chamber provided an inner 'experimental area' of 16 buckets with a border of 20 buckets. In the horizontal plane, steep environment gradients existed at the edge of the 'crop', but in the experimental area the gradients were mild. The buckets were placed close together on three trolleys which could be 
Fig. 1. Cross-section through the climate chamber showing the pattern of air flow (dotted lines with arrow-heads) and the position of plants, lamps, balance, and masts with sensors. $T=$ temperature sensor. RH = air humidity sensor. Heights above soil level in the buckets $(\mathrm{Bu})$ are given in $10^{-2} \cdot \mathrm{m}$. Levels 1,2 and 3 indicate the three positions of the buckets successively taken during the experiment. $\mathrm{B}=$ balance for transpiration measurements. HPLR $400=$ high pressure mercury vapour lamp $400 \mathrm{~W} . \mathrm{TL}=\mathrm{TL} 40 \mathrm{~W}$ tubular lamps.

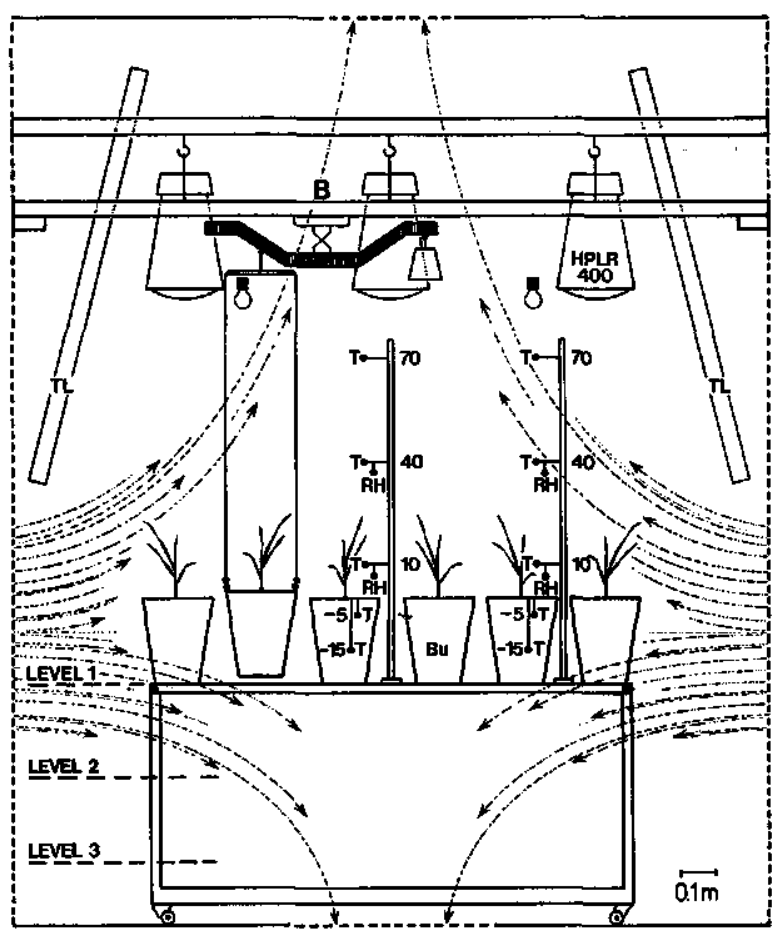

Fig. 1. Dwarsdoorsnede door de klimaatkamer met de stroomrichting van de lucht (gestippelde lijnen met pijltjes) en de plaats van planten, lampen, balans en masten met meetvoelers. $T=$ temperatuurvoeler. $R H=$ voeler voor luchtvochtigheid. De hoogte van de meetvoelers t.o.v. het grondniveau in de emmers $(B u)$ is aangegeven in $10^{-2}$.m. Niveaus 1,2 en 3 duiden de drie hoogten van de emmers aan, achtereenvolgens ingenomen gedurende de proef. $B=$ balans voor transpiratiemetingen. HPLR $400=$ hoge druk kwiklamp $400 \mathrm{~W} . T L=T L$ fluorescentie lampen $40 \mathrm{~W}$.

moved to facilitate watering and sampling.

Some plants in the border buckets near the long axis of the chamber (Fig. 2) were destructively sampled in the period before inoculation. After inoculation, 16 plants were sampled (four per disease treatment) at one-week intervals. The four plants per treatment were taken at random from two buckets. The sampling of plants for the determination of dry weight and leaf area commenced four weeks after sowing. In the period before inoculation only three plants per sample were taken; after inoculation, a sample consisted of four plants per treatment (16 plants per sample). Results are presented in terms of the mean values per plant.

Transpiration was measured continuously using three pivot spring balances (Tegelaar and Van der Wal, 1974). The transpiration calculated during the first half of the growing period was based on 3 buckets containing 6 plants each, each of them being 
Fig. 2. Projection on a horizontal plane in the climate chamber. The places of the buckets are indicated by rectangles: those with a diagonal represent buckets of the 'border', those without a diagonal constitute the 'experimental area'. In one rectangle, the six bags with one plant each are indicated. The diagram shows the positions of TL lamps (TL) along the perforated walls and of the HPLR lamps above the buckets (dotted circles). $\mathrm{CS}=$ position of sensors of the control equipment. The multipoint plug is used in signal transport from the sensors to the recorder room. A, B, C, and D indicate positions of masts with sensors. B1, B2, and B3 = position of the three buckets hanging from the balances 1,2 , and 3 .

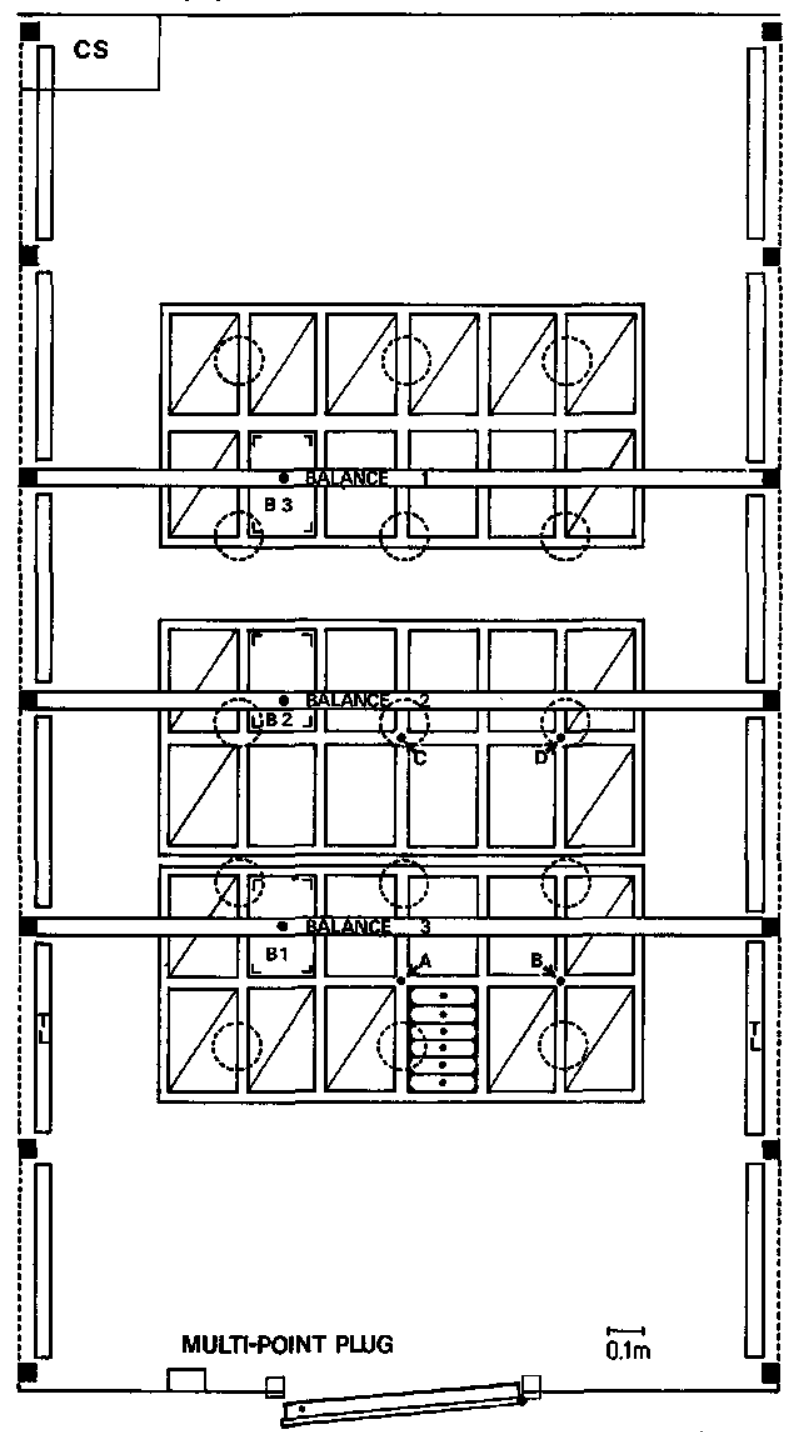

Fig. 2. Horizontale projectie in de klimaatkamer. De plaats van de emmers is aangeduid met rechthoeken; die met een diagonaal duiden emmers aan die tot de 'rand' behoren, die zonder diagonaal vormen het 'proefgebied'. In één emmer zijn de zes zakken met elk een plant aangeduid. De plaatsen van de TLbuizen bij de muren (TL) en die van de HPLR-lampen (gestippelde cirkels) zijn eveneens aangegeven. $C S=$ voelers van de regelapparatuur van de klimaatkamer. De meerpuntsplug wordt gebruikt bü het overbrengen van de signalen van de meetvoelers naar de recorderkamer. $A, B, C$ en $D$ geven de plaatsen van de meetmasten aan. $B 1, B 2$ en $B 3=$ plaatsen van de drie emmers aan de balansen 1,2 en 3. 
on the same balance in this period. The 3 balances allowed of the monitoring of transpiration in 21 buckets during one week, and after inoculation a rotation scheme was applied so that simultaneous measurement of more than one replicate in any treatment was avoided as much as possible. A correction factor for evaporation was calculated from the results of measurements during the first four days of the growth period, when the first leaf was emerging. A mean specific correction factor of $30.1 \times$ $10^{-3} \mathrm{~kg}$. day ${ }^{-1}$. plant ${ }^{-1}$ (strictly, per soil bag) was obtained. For each treatment, an estimate of the daily transpiration was made by linear interpolation of the original transpiration data.

\section{Statistical methods}

Responses like leaf area and dry weight of individual plants show great variance. In view of the limitations of available space and labour, a choice had to be made between either just a few large samples, or more but smaller samples. If a few large samples are used the information about the state of the plant at sampling date is relatively accurate but little insight is gained into the growth process itself. In this approach, called cross-sectional approach (Zadoks, 1972), emphasis is on the best possible estimate of the state of the plant; analysis of variance is a suitable technique to detect significant differences between the levels of disease treatment. In the present paper, where emphasis is on the process itself, a longitudinal approach is more appropriate. Consequently, other statistical methods have to be used in order to detect differences between effects of the various levels of disease treatment during a certain period. As the longitudinal approach necessitates frequent sampling, the choice fell on taking small samples: four plants per level of disease treatment and per sampling date, and six sampling dates in the period from inoculation to harvest.

The first step analysing the data was a test of the significance of the differences between the response curves corresponding with the four levels of disease treatment. All six possible combinations of two levels of disease treatment (C-R, C-S, C-I, R-S, R-I, and S-I) were studied. One other combination, C-R-S $+\mathrm{I}$, was added to see whether the sum $(R+S)$ of the effects of the rust infection alone $(R)$ and the glume blotch infection alone (S) was different from the effect of both pathogens together in the same plant (I). In all combinations, the difference between two concomitant observations was calculated for each of the sampling dates. For each type of response, the regression of the difference on time was calculated using the model $y=a+b x$, where $a$ and $b$ are constants, and $y$ is the expected value of the difference at time $x$. The t-values of the parameters in the regression equations were calculated, and subjected to Student's t-test for significance at the 0.10 level. A significant difference from zero of one of the parameter estimates $a$ and $b$ was accepted as evidence that the effects of two disease treatment levels were systematically different.

The second step was the calculation of points of regression curves for each of the responses and for each of the levels of disease treatment. The choice of the models used in the calculations depended on the expected shape of the curves. For total dry weight per plant and total transpiration over the full growth period a sigmoid curve was expected, and a logistic regression was applied (Nair, 1954): $y=k /\left(1+b^{c x}\right)$, where $b, c$ and $k$ are constants, $y$ is the expected value of the response at time $x$, and e the base to the natural logarithms. For the period from inoculation to harvest, only 
segments of sigmoid curves could be expected, and here a three parameter semilogarithmic regression model was applied: $y=a+b e^{c x}$, where $a, b$ and $c$ are again constants. For technical reasons, a two-parameter semi-logarithmic regression model was used in cases where a decrease in the response value $y$ with time could not be excluded: $y=b e^{c x}$.

\section{Materials and techniques}

The description of the environment follows the guidelines proposed by the A.S.H.S. Committee on Growth Chamber Environments (1972).

\section{The environment}

The climate chamber. The main voltage was $220 \mathrm{~V}, 50 \mathrm{~Hz}$. The climate chamber was c. $4 \mathrm{~m}$ long, $2.4 \mathrm{~m}$ wide, and $2.5 \mathrm{~m}$ high (Fig. 1 and Fig. 2).

Light sources. Three types of lamp were used simultaneously; three rows of five $400-\mathrm{W}$ Philips HPLR in a grid arrangement, spaced $0.5 \mathrm{~m}$ between centres; two rows of 40-W incandescent lamps suspended between the rows of HPLR bulbs, spaced at $0.2 \mathrm{~m}$ intervals; two rows of $40 \mathrm{~W} 33 \mathrm{RS}$ Philips TLMF fluorescent tubular lamps, placed almost vertically near the long walls of the chamber, $0.06 \mathrm{~m}$ apart. Differences in light intensity of less than $20 \%$ between the HPLR lamps were attributed to differences in the ages of the lamps. Distances between lamps, and from lamps to plant tips were selected so that the radiation cones of the lamps overlapped in the 'experimental area' at the level of the plant tips. Heat shields between the plants and the lamps were not used to avoid interruption of the vertical air flow in the chamber, reduction of the heat dissipation from the lamps, and interception of the near-UV radiation (360-380 $\mathrm{nm}$ ). The latter is of critical importance in the formation of pycnidia (Van der Wal et al., unpublished).

Light intensity. Light intensity was measured with two instruments. One was a spherical light intensity meter (photocell, measuring angle $4 \pi \mathrm{r}$, cosine corrected; Wassink and Van der Scheer, 1951), calibrated in lux and in W. $\mathrm{m}^{-2}$ for HPLR lamps. During the experiment, the light intensity at various points between the plants was measured eight times. At plant tip level, $0.75 \mathrm{~m}$ under the HPLR lamps, the intensity was 45 Klux, equivalent to $350 \mathrm{~W} \cdot \mathrm{m}^{-2}$. The platforms supporting the plants were lowered when the distance between plants and HPLR lamps became less than $0.75 \mathrm{~m}$. When the plants reached their maximum leaf area, the light intensity between the plants at $0.10 \mathrm{~m}$ above soil level was c. $3 \mathrm{Klux}\left(\mathrm{c} .23 \mathrm{~W} \cdot \mathrm{m}^{-2}\right)$. The other instrument was a KIPP solarimeter (thermopile, measuring angle $2 \pi \mathrm{r}$, without cosine correction, type $\mathrm{CM} 5$ ). At plant tip level c. $180 \mathrm{~W} \cdot \mathrm{m}^{-2}$ was recorded, confirming the result obtained with the spherical light meter; the latter records values roughly twice those recorded by flat light meters in comparable situations.

Photoperiod. A diurnal cycle of $16 \mathrm{~h}$ light and $8 \mathrm{~h}$ dark was employed. The fluorescent and incandescent lamps, and four of the HPLR lamps were switched on at the beginning of the light period. Then, at approximately 10 minutes' intervals, the remaining 
Table 1. Diurnal pattern of temperature and relative humidity of the air entering the climate chamber, as registered by means of the sensors of the climate chamber control equipment (CS in Fig. 2). The calculated daily mean temperature was $17.2^{\circ} \mathrm{C}$. Note the difference between the daily mean temperature of the incoming air and the mean temperatures in the experimental area between the plants (Table 2).

\begin{tabular}{lll}
\hline $\begin{array}{l}\text { Period (h) } \\
\text { from--to }\end{array}$ & $\begin{array}{l}\text { Temperature }\left({ }^{\circ} \mathrm{C}\right) \\
\text { from-to }\end{array}$ & $\begin{array}{l}\text { Rel. humidity }(\%) \\
\text { from-to }\end{array}$ \\
$07.15-11.15$ & $14.8-20.1$ & $80-76$ \\
$11.15-19.00$ & $20.1-20.0$ & $76-78$ \\
$19.00-23.05$ & $20.0-14.7$ & $78-75$ \\
$23.05-07.15$ & $14.7-14.8$ & $75-80$ \\
\hline
\end{tabular}

Tabel 1. De dagelijkse gang van temperatuur en relatieve luchtvochtigheid van de in de klimaatkamer binnenstromende lucht, geregistreerd met behulp van de meetvoelers van de regelapparatuur (CS in Fig. 2). De berekende gemiddelde dagtemperatuur is $17.2^{\circ} \mathrm{C}$. Zie het verschil tussen de gemiddelde temperaturen van de instromende lucht en die van de lucht tussen de planten in het proefvak (Tabel 2).

HPLR lamps were switched on in two groups of four and a final group of three. At the end of the light period, the lights were switched off over a half-hour period in the same order.

Air movement. The general pattern of air movement is indicated in Fig. 1. Incoming air at c. $0.1 \mathrm{~m}$ from the wall had a velocity of c. $0.6 \mathrm{~m} . \mathrm{s}^{-1}$, measured with a Hastings non-directional wind velocity probe (type N-7B; meter model ERM-1, Hastings). At flag leaf level between the plants the wind speed was c. $0.3 \mathrm{~m} . \mathrm{s}^{-1}$. Although there was a regular fluctuation in windspeed with a period of a few minutes, no systematic changes in average windspeed occurred during the experiment. The measurements were repeated eight times at fortnightly intervals.

Air temperature. Table 1 shows the temperature pattern of the incoming air recorded by the climate chamber control equipment throughout the experiment. The temperature in the growth chamber differed considerably from that of the incoming air. A distinct temperature profile in the 'experimental area' was caused by the large heat output of the lamps in the absence of a heat shield. Air temperatures between the plants were measured with $0.5 \mathrm{~mm}$ shielded copper constantan thermocouples. Soil temperatures were measured with similar thermocouples mounted in the tips of 0.15 $\mathrm{m}$ injection needles (Schurer, pers. commun.). Standard aluminium laboratory stands were used to support thermocouples at $0.10 \mathrm{~m}$ (lower leaf level), $0.40 \mathrm{~m}$ (second leaf level), and $0.70 \mathrm{~m}$ (flag leaf level) above the soil surface. Towards the end of the experiment sensors were added at $1.00 \mathrm{~m}$ (head level) above the soil surface. Four stands were arranged so that two were in the centre of the inner experimental area and two near the border (Fig. 1 and 2, Table 2).

Leaf temperature. Leaf temperature was measured with a 'Stoutjesdijk' infrared radiometer (Stoutjesdijk, 1966). Generally, leaf temperature was a few tenths of a degree $\mathrm{C}$ lower than that of the ambient air at the same time and position in the climate chamber. Temperature measurements of various plant organs indicated that 
Table 2. Maximum $\left(T_{\max }\right)$, minimum $\left(T_{\mathrm{mia}}\right)$, and mean $\left(\mathrm{T}_{\text {mean }}\right)$ temperatures measured in the experimental area between the plants by the sensors on the four masts (Fig. 1 and 2). The coefficients of variation $(\mathrm{CV})$ of the measurements indicate the temperature variations in the horizontal plane. The figures are derived from the full-hour records during one day, with the buckets at level 2 (Fig. 1).

\begin{tabular}{|c|c|c|c|c|c|c|c|c|}
\hline \multirow{2}{*}{$\begin{array}{l}\text { Height } \\
\text { above } \\
\text { soil (m) }\end{array}$} & \multicolumn{3}{|c|}{$\mathrm{T}_{\max }\left({ }^{\circ} \mathrm{C}\right)$} & \multicolumn{3}{|c|}{$\mathrm{T}_{\min }\left({ }^{\circ} \mathrm{C}\right)$} & \multicolumn{2}{|c|}{$\mathrm{T}_{\text {mear }}\left({ }^{\circ} \mathrm{C}\right)$} \\
\hline & value & time & $\mathrm{CV}$ & value & time & $\mathrm{CV}$ & value & $\mathrm{CV}$ \\
\hline 1.00 & 25.0 & 18.00 & 0.07 & 14.6 & 06.00 & 0.02 & 20.1 & 0.04 \\
\hline 0.70 & 24.5 & 18.00 & 0.02 & 15.0 & 06.00 & 0.01 & 20.0 & 0.02 \\
\hline 0.40 & 23.6 & 18.00 & 0.04 & 14.7 & 06.00 & 0.03 & 19.4 & 0.03 \\
\hline 0.10 & 22.9 & 18.00 & 0.02 & 15.2 & 06.00 & 0.02 & 19.4 & 0.01 \\
\hline-0.05 & 21.5 & 20.00 & 0.02 & 17.4 & 09.00 & 0.04 & 19.6 & 0.004 \\
\hline-0.15 & 21.3 & 20.00 & 0.01 & 16.9 & 09.00 & 0.04 & 19.3 & 0.004 \\
\hline
\end{tabular}

Tabel 2 . Waarden en tijdstippen van de maximum $\left(T_{\max }\right)$, minimum $\left(T_{\text {min }}\right)$ en gemiddelde $\left(T_{\text {mean }}\right)$ temperaturen gemeten in het proefvak tussen de planten door meetvoelers aan de vier masten (Fig.1 en 2 ). De variatiecoëfficienten ( $\mathrm{CV}$ ) van de metingen met behulp van de vier meetvoelers op de aangegeven hoogten worden gegeven om de temperatuurvariaties in het horizontale vlak aan te duiden. De gegevens zijn ontleend aan metingen op de hele uren gedurende één dag, met emmers op niveau 2(Fig. 1).

there were temperature gradients along the plants related to the temperature gradients of the ambient air.

Air humidity. The humidity changes of the incoming air, recorded by the growth chamber control equipment, are shown in Table 1. Shielded wet and dry bulb unventilated thermocouples (Schurer, 1972) were used for the measurement of humidity among the plants. The thermocouple elements were calibrated in a radiation-free chamber against high-precision thermometers at a wind speed (c. $0.4 \mathrm{~m} . \mathrm{s}^{-1}$ ) similar to the wind speed recorded around the plants in the climate chamber. The humidity sensors were placed at $0.10 \mathrm{~m}$ and $0.40 \mathrm{~m}$ above the soil surface (Fig. 1) at the $0.10 \mathrm{~m}$ level, relative humidity was in the range of $70 \%$ to $80 \%$, and at the $0.40 \mathrm{~m}$ level it was in the range of $60 \%$ to $75 \%$.

$\mathrm{CO}_{2}$. The air supply for the climate chamber was drawn from about $20 \mathrm{~m}$ above ground level and was filtered to remove dust and other particles. The rate of circulation through the climate chamber was c. $6,000 \mathrm{~m}^{3} \cdot \mathrm{h}^{-1}$. The leakage from the chamber because of internal overpressure was c. $150 \mathrm{~m}^{3} \cdot \mathrm{h}^{-1}$. The average growth rate being c. $0.3 \times 10^{-3} \mathrm{~kg}$. plant ${ }^{-1}$. day ${ }^{-1}$ dry matter for the 200 plants in the chamber, the rate of $\mathrm{CO}_{2}$ fixation was c. 2 moles.day ${ }^{-1}$ or c. $0.05 \mathrm{~m}^{3}$.day-1 $\left(0.002 \mathrm{~m}^{3} . \mathrm{h}^{-1}\right)$. Assuming that the $\mathrm{CO}_{2}$ concentration of the incoming air was $0.03 \%$, the $\mathrm{CO}_{2}$ requirement of the plants was c. $5 \%$ of the $\mathrm{CO}_{2}$ input to the climate chamber. The $\mathrm{CO}_{2}$ consumption was partially compensated by the $\mathrm{CO}_{2}$ exhaled by persons working in the climate chamber.

Root medium. A commercial potting soil, TRIO 17, was used with an addition of some clay. An analysis of the mixture is given in Table 3 . About $1.2 \mathrm{~kg}$ of soil (dry weight $0.65 \mathrm{~kg}$ ) was transferred to polythene bags, $0.20 \mathrm{~m}$ long and $0.25 \mathrm{~m}$ deep, which were packed to form a flat-sided unit about $0.04 \mathrm{~m}$ wide. The lower ends of the 
Table 3. Results of an analysis of the soil, made at the beginning of the experiment by the Laboratory for Soil and Crop Testing.

\begin{tabular}{lr}
\hline Ph-water: & 5.9 \\
Organic matter: & $44 \%$ \\
NaCl: & $330 \mathrm{ppm}$ \\
N- water: & $1540 \mathrm{ppm}$ \\
P- water: & $440 \mathrm{ppm}$ \\
K- water: & $1260 \mathrm{ppm}$ \\
$\mathrm{MgO}-\mathrm{NaCl}:$ & $2138 \mathrm{ppm}$
\end{tabular}

Tabel 3. Resultaten van een grondanalyse, uitgevoerd bij het begin van de proef door het Bedrijfslaboratorium voor Grond- en Gewasonderzoek.

bags were perforated. Six such bags were placed side to side in rectangular polythene buckets, $0.27 \times 0.20 \mathrm{~m}$ at the mouth, and $0.27 \mathrm{~m}$ deep. Seeds of wheat cv. Kolibri were pregerminated in petri dishes for 2 days. One seed per bag was planted centrally c. $0.025 \mathrm{~m}$ below the soil surface, so that each bucket contained a row of 6 plants at c. $0.04 \mathrm{~m}$ distance within the row. This arrangement made possible the removal of a single plant from the climate chamber with a minimum of disturbance to the remaining plants. The bags did not fill the entire volume of a bucket: the gaps remaining between the bags and the walls of the bucket facilitated watering and aeration of the soil.

Water. The maximum water content of the soil during the experiment was $1.5 \mathrm{~kg}$ water per $2.5 \mathrm{~kg}$ soil, giving a water potential of c. $-80 \mathrm{~J} . \mathrm{kg}^{-1}$. Tap water was added on alternate days from sowing to stage 30 , and thence daily until harvest. A bucket received not more than one litre at a time. The result was a fluctuation in the water content of the soil and a variation in soil water potential approximately within the range of $-80 \mathrm{~J}^{\mathrm{kg}} \mathrm{kg}^{-1}$ to $-370 \mathrm{~J} . \mathrm{kg}^{-1}$. The latter value was the lowest encountered in the samples taken for determining the water potential. The mean value of all samples taken immediately before watering was $-212 \pm 19$ (S.E.) J.kg-1 , measured by thermocouple psychrometry. Water was added between the bags and the walls of the buckets, and some water was also applied to the open soil surface to ensure that the fertilizer was washed into the soil.

Nutrients. Nineteen days after sowing, $10^{-3} \mathrm{~kg}$ pulverized commercial fertilizer (Granumix $18 \% \mathrm{~N}, 18 \% \mathrm{P}, 12 \% \mathrm{~K}$ ) per plant was applied to the soil surface at least $0.05 \mathrm{~m}$ from the base of the stem. No visible trace remained there after one week.

The host

Seed. The seeds of 'Kolibri' used in this experiment were harvested from previous experiments in the climate chamber, and were free of common pathogens such as Fusarium spp. and Septoria spp. They had been stored in the coldroom at $4^{\circ} \mathrm{C}$. Germination percentage was over 95 . Selected seedlings of equal size were planted in polythene bags as described under Root medium. 
Dry weight, leaf area, development. After removal of the sample plants from the growth chamber, the soil was washed off the roots, the leaf area was measured by a photo-electric method (ref. Automatic type AAM-5 leaf area meter, Hayashi Denko Co. Ltd, Japan), and the axial development was determined. Leaves per axis and leaf area per axis were recorded, and the leaves, stems (with sheaths), and heads of each axis were grouped together and dried overnight in an oven at $105^{\circ} \mathrm{C}$. A comprehensive analysis of changes in axial distribution and weight of plant organs in the course of time was, however, beyond the scope of this experiment.

\section{The rust}

Prevention of cross infection. By proper setting of the climate chamber, using a separate incubator for the inoculations, and inoculating with pathogens that require free water on the leaf surface for spore germination and penetration, it was possible to place uninfected control plants next to abundantly sporulating rusted plants and plants heavily infected with glume blotch. The application of fungicides in order to keep the control plants free of infection was therefore not needed.

Rust inoculum. The rust material used was a mixture which originated from the Flamingo race, isolated by Zadoks in 1961 as No. 1037. Uredospores in quantities of the order of $10^{-2} \mathrm{~kg}$ were produced before the commencement of this experiment. The spores were stored in glass ampoules under liquid nitrogen (Loegering et al., 1961).

Timing of inoculation. The rust inoculation was performed at the $75 \%$ heading stage, scale value 56 (Zadoks et al., 1974), 60 days after planting. At this growth stage about half of the final dry matter production has accumulated. Rooting and tillering have been completed, leaf area is at its maximum. The effect of the disease treatment at this stage must be sought mainly in the grain filling.

Inoculum density. An inoculum density of c. 20 spores.mm $\mathrm{m}^{-2}$ leaf surface was required to achieve a $10 \%$ infection at the end of the latent period. The relation between inoculum density and $\%$ of infection of this pathogen-cultivar combination had been established previously. A $10 \%$ infection is serious when it occurs in the field at this stage of development, but usually not disastrous. Increases in the percentage of infection were a result of growth of the pathogen, and were not caused by re-infection. Each bucket of plants was inoculated separately in a settling tower (Eyal et al., 1968), diameter $0.50 \mathrm{~m}$, height $2.50 \mathrm{~m}$, with $50 \mathrm{mg}$ of uredospores, disposed by means of a $\mathrm{CO}_{2}$ gun. There was no significant difference in the percentage of infection between plants in different buckets. Spore densities achieved in the settling tower were mea-

Table 4. The development of the uninfected plant (C) with time ( $t$ ) in days after planting. The development is expressed in the decimal scale of Zadoks et al. (1974).

\begin{tabular}{lrrrrrrrrrr}
\hline $\mathrm{C}$ & 05 & 11 & 30 & 32 & 50 & 60 & 71 & 85 & 87 & 92 \\
$\mathrm{t}$ & 0 & 7 & 28 & 36 & 44 & 51 & 70 & 83 & 92 & 98 \\
\hline
\end{tabular}

Tabel 4. De ontwikkeling van de niet-geinfecteerde plant $(C)$ in de loop van de tijd ( $t$ ) in dagen na het planten. De ontwikkeling is aangeduid met behulp van de decimale schaal van Zadoks et al. (1974). 
sured by placing vaseline smeared microscope slides horizontally in the tower near the flag leaves of the plants. Densities of 20 to 30 spores. $\mathrm{mm}^{-2}$ were found on the slides, and there were no significant differences between slides. The percentage of germination of the spores on the leaf surface was determined after the incubation period using collodion strips and lactophenol cotton blue; c. $82 \%$ spore germination was found.

Incubation. Incubation was carried out in a cabinet $2.00 \times 1.25 \times 2.20 \mathrm{~m}$, with an inner lining of muslin draped over a metal frame, which fitted inside a large metal tray with water. Above the muslin ceiling, a copper pipe with numerous $0.5 \mathrm{~mm}$ perforations was mounted over the full length of the cabinet. By this means water was sprayed from the outside over the muslin curtain. The water was collected in the tray and was allowed to drain away. The entire structure was covered by a black polythene sheet. The mean internal temperature was c. $18^{\circ} \mathrm{C}$. Inoculated plants remained in the incubator overnight for about $11 \mathrm{~h}$, and were then returned to the climate chamber.

Disease assessment. The disease assessment was based on the standard scales compiled by W. C. James (1971). Ten days after inoculation the percentage of infection was between 10 and 25 .

\section{The glume blotch}

Inoculum. After flowering, plants grown in the growth chamber were inoculated with a mixture of Septoria nodorum isolates. Infected seeds were stored in the cold room at $4^{\circ} \mathrm{C}$ for prolonged periods. The seeds apparently carried a pure $S$. nodorum infection. After mild surface sterilization with hypochlorite followed by washing in sterile water, the seeds were placed on $2 \%$ wheatmeal-agar to obtain the fungus in the form of agar plate colonies. When, with a diurnal cycle, these colonies were exposed at room temperature to light containing wavelengths in the range of $360-380 \mathrm{~nm}$, concentric rings of pycnidia were produced within five days. Recently harvested seeds were used as the source of the pathogen, and the agar colonies were checked for irregularities in growth rate, sector formation, and size and density of the pycnidia. Spore suspensions were prepared from the regularly growing colonies only, and after the spore concentration was adjusted to c. $10^{5}$ spores. $\mathrm{ml}^{-1}, 9 \mathrm{~cm} \varnothing$ petri dishes containing wheat meal agar were inoculated with $1 \mathrm{ml}$ of the spore suspension, and incubated at $20^{\circ} \mathrm{C}$ under TLMF $40 \mathrm{~W} 33 \mathrm{RS}$ fluorescent lamps at c. $20 \mathrm{Klux}$, with a diurnal cycle of $16 \mathrm{~h}$ light and $8 \mathrm{~h}$ darkness. A yield of about $10^{8}$ spores.dish $^{-1}$ was harvested after 10 days.

Timing of inoculation. The inoculation with Septoria was performed after the inoculation with rust but before the rust started to sporulate, so as to avoid re-inoculation by rust in the 1 treatment.

Inoculum density. The volume and concentration of the spore suspension was adjusted to produce an average spore density of c. 20 spores. $\mathrm{mm}^{-2}$ leaf surface in order to obtain a $10 \%$ infection. The relation between spore density, incubation and percentage of attack had been established before. A De Villbiss atomizer was employed to spray 
the spore suspension on the plants. Spore density was found to be between 20 and 30 spores. $\mathrm{mm}^{-2}$. Spore germination was over $90 \%$.

Incubation. The inoculated plants were incubated overnight for $11 \mathrm{~h}$, as described above, on three consecutive nights, and the plants were kept in the climate chamber during the intervening daytime periods. There was no significant difference in percentage of infection between plants in different buckets on the 8th day after inoculation, when the percentage of infection was between 10 and 25 on the leaves, and c. 15 on the heads.

\section{Management of the experiment}

The attitude of the persons taking care of the experiment described here was similar to that of people working in the intensive care unit of a hospital. The instrumentation had attained a high degree of sophistication. The behaviour of the diseased plants was constantly supervised, and at times instant action was required. In order to carry out this aspect of the work it was necessary that at least one person was available at any time during a period of several months.

Transpiration was monitored continuously. Irregularities in transpiration were interpreted as an indication of overwatering, underwatering, or disturbance in climate chamber control. Great alertness was necessary to avoid contamination with common pests such as powdery mildew and aphids. Mildew is difficult to control in climate chambers once it has been introduced. The control of aphids, although possible by periodical treatments with non-persistent organic phosphorous compounds such as DDVP, inhibits the rust and/or injures the rusted plant. The preventive measures were successful and this experiment was carried out without contamination, although both authors were involved in field work during the period of the experiment.

\section{Results}

\section{General remarks}

The presentation of results reflects two steps in data processing. The first step was a test of differences between concomitant values of a response for all possible combinations of two levels of disease treatment. The regression of differences between the values paired per sampling date on time was calculated; the t-values of the parameters of the regression equations are shown in Table 5. This table allows of comparing the 'noise' in the data with the magnitude of the effects to be studied. Table 6 shows the decisions about the significance of the differences, based on Student's t-test.

The second step was the calculation of points of regression curves for each response. Figures 4, 5, 6, 7, 8 and 9 show the resulting regression curves and Tables 7, 8, 9, 10 and 11 the calculated values of the corresponding parameters.

The climate chamber was set at a diurnal rhythm approximating good weather conditions in the Netherlands at flowering time of spring wheat: a day length of c. $16 \mathrm{~h}$, a day temperature of c. $25^{\circ} \mathrm{C}$ and a night temperature of c. $15^{\circ} \mathrm{C}$. With such an environment during the whole growth period, rapid growth and development in the earlier stages of the plant could be expected. The growth period was c. 3.5 months, which is c. 1.5 months shorter than the growth period of spring wheat in the field. 
Table 5. The t-values of the regression constants (a) and the regression coefficients (b) are given for seven combinations of treatment levels and six responses. These values were obtained after regression of the differences between two concomitant values $\left(y_{i}\right)$ per observation day $\left(x_{i}\right)$ versus time $(x)$. Details see text. There are n-2 $=4$ degrees of freedom for these t-tests, except for kernel weight and kernel number where $\mathrm{n}-2=2$. C-R, C-S, and C-I were tested one-tailed, the others two-tailed $(\mathrm{p} \leqslant 0.10)$. $\mathbf{C}=$ uninfected plant; $\mathbf{R}=$ plant infected with rust; $\mathbf{S}=$ plant infected with Septoria; $\mathbf{I}=$ plant infected with rust and Septoria.

\begin{tabular}{|c|c|c|c|c|c|c|c|c|c|c|c|c|}
\hline & \multicolumn{2}{|c|}{ Roots } & \multicolumn{2}{|c|}{ Leaves } & \multicolumn{2}{|c|}{ Stems } & \multicolumn{2}{|c|}{ Heads } & \multicolumn{2}{|c|}{$\begin{array}{l}\text { Kernel } \\
\text { weight }\end{array}$} & \multicolumn{2}{|c|}{$\begin{array}{l}\text { Kernel } \\
\text { number }\end{array}$} \\
\hline & $\mathbf{a}$ & b & a & b & $\mathbf{a}$ & b & $\mathbf{a}$ & b & a & b & $\mathbf{a}$ & b \\
\hline C-R & 0.96 & -1.08 & 0.91 & -0.97 & 0.99 & 0.71 & 0.07 & 1.30 & -1.07 & 1.49 & -0.49 & 1.83 \\
\hline $\mathrm{C}-\mathrm{S}$ & -0.28 & 0.61 & -1.01 & 2.33 & -1.98 & 2.96 & -2.29 & 4.83 & -1.12 & 1.45 & -0.41 & 1.80 \\
\hline C-I & 1.25 & 0.13 & 0.31 & 0.20 & 0.43 & 1.03 & 0.67 & 3.28 & 3.22 & -0.10 & 8.48 & -4.71 \\
\hline R-S & -1.28 & 1.77 & -2.00 & 3.35 & -5.30 & 4.45 & -2.69 & 3.56 & 2.66 & -1.47 & -0.33 & 1.53 \\
\hline R-I & 0.21 & 1.74 & -0.85 & 1.55 & -0.39 & 0.55 & 0.95 & 3.24 & 3.04 & -1.71 & 6.05 & -3.88 \\
\hline $\mathbf{S}-\mathbf{I}$ & 2.46 & -1.02 & 1.04 & -1.65 & 2.28 & -1.72 & 7.91 & -1.11 & 3.17 & -1.79 & 3.39 & -2.89 \\
\hline $\mathbf{C}-\mathbf{R}-\mathbf{S}+\mathbf{I}$ & -0.40 & -0.42 & -0.18 & 0.61 & -1.14 & 1.73 & 4.45 & 0.41 & -1.93 & 1.70 & -3.05 & 2.82 \\
\hline
\end{tabular}

Tabel 5. De t-waarden van de regressieconstanten (a) en de regressiecoëfficienten (b) zijn vermeld voor zeven combinaties van behandelingsniveaus en voor 6 responsies. Deze waarden zijn verkregen na regressie van het verschil van twee bijeengevoegde waarden $\left(y_{1}\right)$ per waarnemingsdag $\left(x_{1}\right)$ tegen de tijd $(x)$. $Z$ ie de tekst voor details. Er zijn $n-2=4$ vrijheidsgraden voor de t-toets, behalve by 'kernel weight' en 'kernel number', waar $n-2=2, C-R, C-S$ en $C-1$ zijn eenzijdig getoetst, de overige combinaties tweezijdig $(p \leqslant 0.10)$.

$C=$ niet geinfecteerde plant; $R=$ plant geinfecteerd met roest; $S=$ plant geinfecteerd met Septoria; $I=$ plant geinfecteerd met roest en Septoria.

Table 6. The decisions about the significance of the differences between disease treatment levels, listed per disease treatment combination $(C-R, \ldots, C-R-S+I)$ and per response. $A+$ (plus) indicates significance, $\mathrm{a}-$ (minus) no significance at a confidence limit $\mathrm{p}>0.90$. The decisions are based on Student's t-values and the degrees of freedom given in Table 5.

\begin{tabular}{|c|c|c|c|c|c|c|c|c|c|c|c|c|}
\hline & \multicolumn{2}{|c|}{ Roots } & \multicolumn{2}{|c|}{ Leaves } & \multicolumn{2}{|c|}{ Stems } & \multicolumn{2}{|c|}{ Heads } & \multicolumn{2}{|c|}{$\begin{array}{l}\text { Kernel } \\
\text { weight }\end{array}$} & \multicolumn{2}{|c|}{$\begin{array}{l}\text { Kernel } \\
\text { number }\end{array}$} \\
\hline & a & b & $\mathbf{a}$ & b & $\mathbf{a}$ & b & $\mathbf{a}$ & b & a & b & $\mathrm{a}$ & $\mathbf{b}$ \\
\hline C-R & - & - & - & - & - & - & - & - & $\rightarrow$ & - & - & - \\
\hline $\mathrm{C}-\mathrm{S}$ & - & - & - & + & + & + & + & + & - & - & - & - \\
\hline C-I & - & - & - & - & - & - & - & + & + & - & + & + \\
\hline $\mathbf{R}-\mathbf{S}$ & - & - & - & + & + & + & + & + & - & - & - & - \\
\hline R-I & - & - & - & - & - & - & - & + & + & - & + & + \\
\hline S-I & + & - & - & - & + & - & + & $\rightarrow$ & + & - & + & - \\
\hline C-R-S+I & - & - & - & - & - & - & + & - & - & - & + & - \\
\hline
\end{tabular}

Tabel 6. Beslissingen over de significantie van de verschillen tussen ziektebehandelingsniveaus, gerangschikt per ziektebehandelingscombinatie $(C-R, \ldots C-R-S+I)$ en per responsie. Een + betekent significantie, een-geen significantie bij een betrouwbaarheidsgrens van $p>0.90$. De beslissingen berusten op de t-waarden van Student en de vrijheidsgraden vermeld in Tabel 5.

Neth. J. Pl. Path. 80 (1974) 
Table 7. Parameter values estimated by means of the calculation of the regression of dry matter data and kernel number on time. The regression equations used are $y=a+b e^{c x}$ for the responses leaves, stems, heads and kernel weight, and $y=b e^{c x}$ for roots and kernel number. Dimensions as in Fig. 4. (minus) means that no value has been estimated, "means that a non-relevant estimate has been made, because of certain properties of the computer programme used. It indicates that the variance in data as compared with the increase with time was too large for a proper estimate to be calculated. The regression curves are shown in Fig. 4.

\begin{tabular}{rcllcll}
\hline & Roots & Leaves & Stems & Heads & $\begin{array}{l}\text { Kernel } \\
\text { weight }\end{array}$ & $\begin{array}{l}\text { Kernel } \\
\text { number }\end{array}$ \\
C a & - & 3.8 & 8.4 & 11.3 & 7.3 & - \\
b & 7.2 & $*$ & $*$ & -1217 & $*$ & 319 \\
c & -0.015 & $*$ & $*$ & -0.071 & $*$ & -0.004 \\
R a & - & 3.7 & 6.9 & 11.0 & 6.2 & - \\
b & 2.8 & $*$ & $*$ & -150 & $*$ & 370 \\
c & -0.004 & $*$ & $*$ & -0.042 & $*$ & -0.006 \\
S a & - & 3.3 & 7.6 & 7.6 & 4.7 & - \\
b & 10.3 & $*$ & $*$ & -213 & $*$ & 562 \\
c & -0.020 & $*$ & $*$ & -0.057 & $*$ & -0.012 \\
I a & - & 3.5 & 6.9 & 6.6 & 4.4 & - \\
b & 8.6 & $*$ & $*$ & -87.4 & -2809 & 72 \\
c & -0.021 & $*$ & $*$ & -0.042 & -0.078 & +0.008 \\
\hline
\end{tabular}

Tabel 7. Parameterwaarden geschat door middel van de berekening van de regressie van droge stof gegevens en aantal korrels op de tijd. De gebruikte regressievergelijkingen zijn y $=a+b e^{\text {cz }}$ voor de responsies 'leaves', 'stems', 'heads' en 'kernel weights' en $y=b e^{\mathrm{cx}}$ voor 'roots' en 'kernel number'. De dimensies zijn als in Fig. 4. Een - (minus) betekent dat geen waarde is geschat, een * betekent dat een niet relevante schatting is gemaakt, als gevolg van bepaalde eigenschappen van het gebruikte computerprogramma. Het betekent hier, dat de spreiding in de gegevens in verhouding tot de toeneming in de tijd te groot was voor een goede schatting. De regressiecurven zijn te zien in Fig. 4.

Fig. 3. Diagram of the axial development of the mature plant. The numbers indicate the order of the axes, modified after Schoute (1910). $0=$ the main stem; 1, 2, 3, and $4=$ first order axes; -..- = axes not always present; $\bullet=$ axis usually fertile.

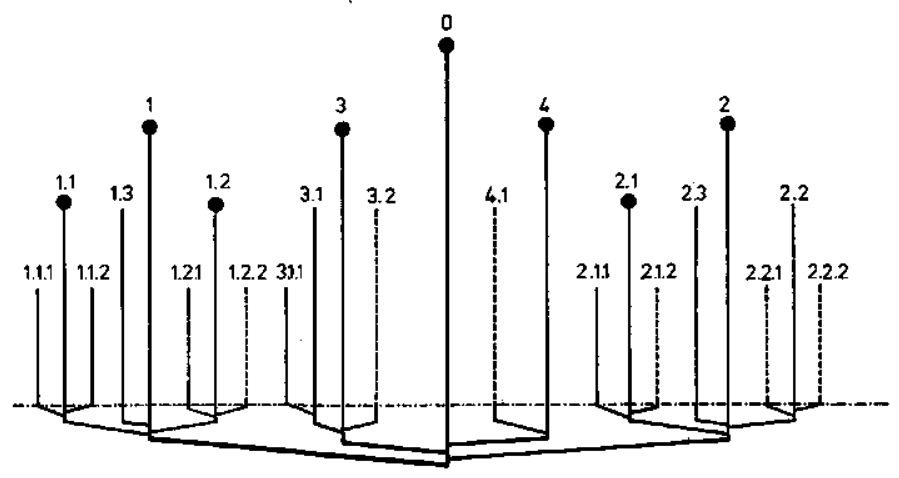

Fig. 3. Diagram van de axiale ontwikkeling van de volwassen plant. De getallen geven de orde van de assen aan volgens het, hier enigszins gewijzigde, systeem van Schoute (1910). $0=$ de hoofdhalm; 1, 2, 3 en $4=$ eerste orde zijassen; $\cdots=$ as niet altijd aanwezig; $\bullet=$ as gewoonlijk fertiel. 
Fig. 4. Mean dry weight (w) per plant organ $\left[10^{-3} \cdot \mathrm{kg}\right.$.plant $\left.{ }^{-1}\right]$ and kernel number per plant in $C, R, S$, and I versus time (t) [day] in the period after inoculation. Symbols as in Table $5: \bullet-C$, $\mathrm{O}-=\mathrm{R}, \Delta \cdots=\mathrm{S}, \Delta \cdots=\mathrm{I}$. For the parameters of the regression curves see Table 7.
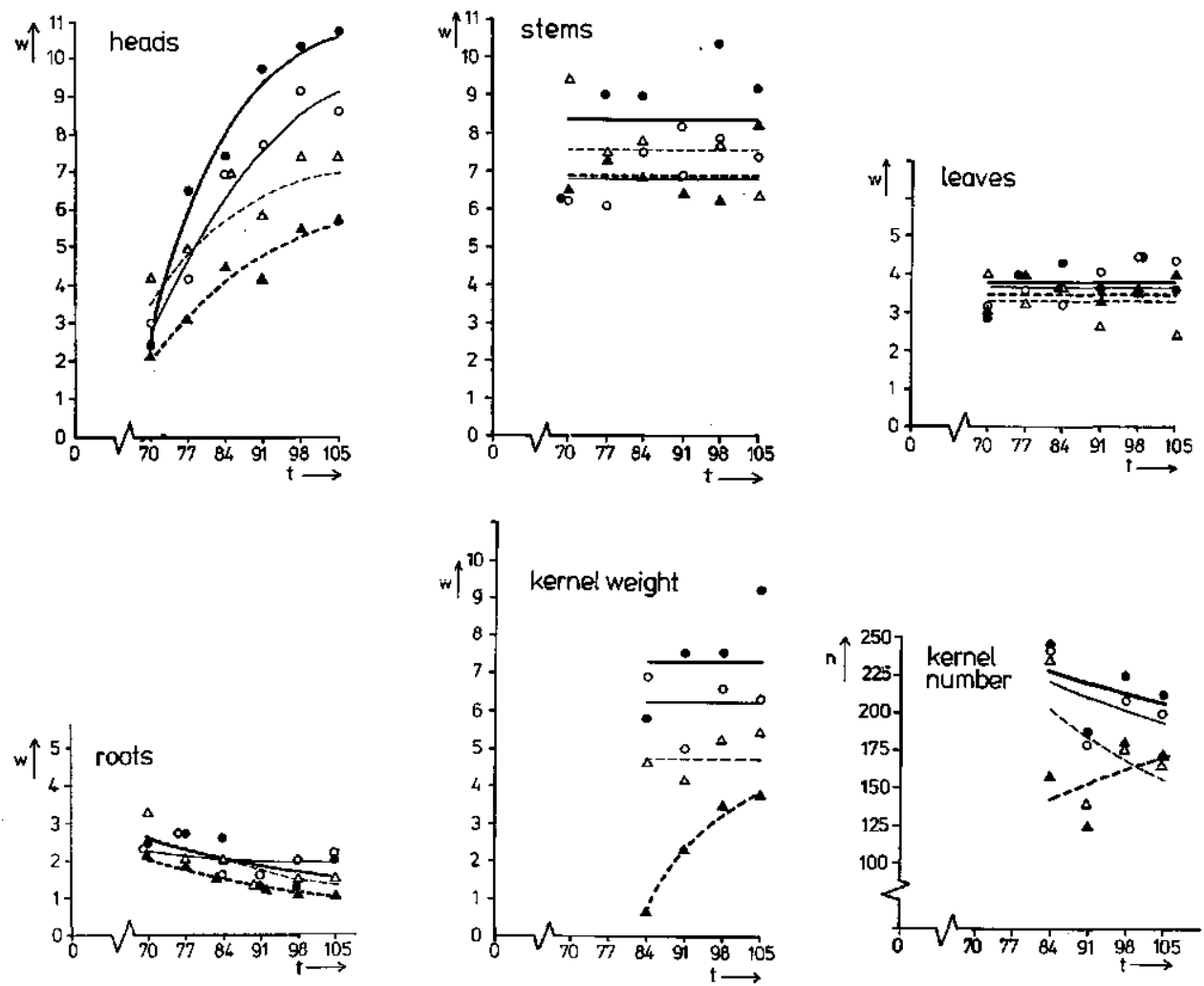

Fig. 4. Gemiddeld drooggewicht $(w)$ per plant-orgaan $\left[10^{-3} . \mathrm{kg}\right.$. plant $\left.{ }^{-1}\right]$ en aantal korrels per plant in $C, R, S$ en I tegen de tijd $(t)[d a g]$ in de periode na de inoculatie. Gebruik van de symbolen is aangegeven in Tabel S: $-=C, \mathrm{O}-=R, \triangle \cdots=S, \Delta \cdots=1$. Voor de parameters van de regressiecurven zie Tabel 7.

\section{Effects of disease treatment on the host}

Development. As the inoculation was timed at stage 56, no effects of disease treatment on development from planting to flowering could be expected. At flowering stage, axial development was completed (Fig. 3). Maturation of the diseased plants proceeded faster than in the uninfected plants.

Growth. As expected, the effects of disease treatment became visible mainly in the growth of the heads. The head weights in S and I were lower than in C (Table 5 and 6, Fig. 4). The head weight in I was less than that in $S$, which in its turn was less than in $R$. The difference in head weight between $C$ and $R$ was not significant. The loss of head weight in $\mathbf{I}$ was larger than the sum of the reductions in $S$ and $R$, indicating interaction (Van der Wal et al., 1970). 


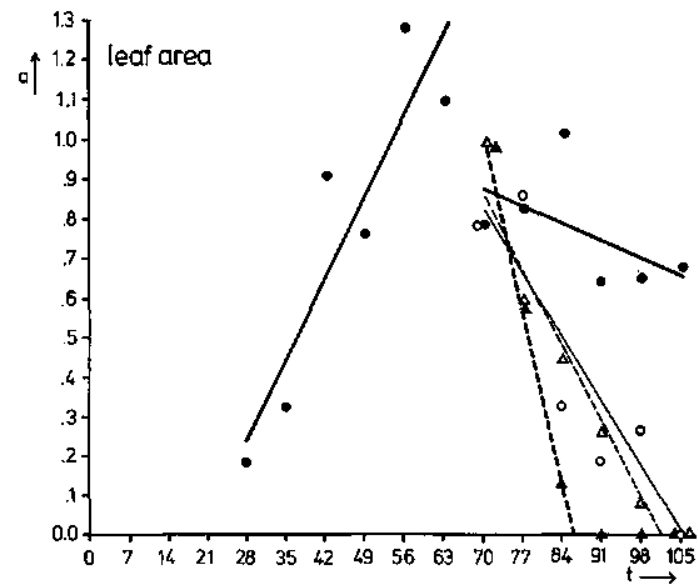

Fig. 5. Mean leaf area $\left[10^{-1} \cdot \mathrm{m}^{2} \cdot\right.$ plant $\left.\mathrm{t}^{-1}\right]$ versus time [day] in $\mathbf{C}, \mathbf{R}, \mathbf{S}$, and I. For dots and lines see Fig. 4. Parameters of the regression curves are given in Table 8.

Fig. 5. Gemiddeld bladoppervlak $\left[10^{-1} \cdot \mathrm{m}^{2}\right.$. plant $\left.^{-1}\right]$ tegen de tijd $[$ dag $]$ bij $C, R, S$ en $I$. Voor de punten en lïnen zie Fig. 4. De parameters van de regressiecurven staan in Tabel 8 .

Table 8. Parameter values estimated by calculating the regression of leaf area $\left[10^{-4} \cdot \mathrm{m}^{2} \cdot\right.$ plant $\left.^{-1}\right]$ on time [day], using the regression equation $y=a+b x$. The periods covered are from day 28 to day 63 for $C_{1}$ and from day 70 to day 105 for the treatment levels $C_{2}, R, S$, and $I$. For the explanation of the symbols see Table 5. For the regression curves see Fig. 5.

\begin{tabular}{lrl}
\hline & \multicolumn{1}{c}{$\mathrm{a}$} & $\mathrm{b}$ \\
$\mathrm{C}_{1}$ & -580 & +29.2 \\
$\mathrm{C}_{2}$ & 1281 & -5.9 \\
$\mathrm{R}$ & 2429 & -23.0 \\
$\mathrm{~S}$ & 2697 & -26.2 \\
$\mathrm{I}$ & 5215 & -60.5 \\
\hline
\end{tabular}

Tabel 8. Parameterwaarden geschat door middel van de berekening van de regressie van het bladoppervlak $\left[10^{-4} . \mathrm{m}^{2}\right.$.plant $\left.{ }^{-1}\right]$ op de tijd [dag], met behulp van de regressievergelijking $y=a+b x$. De perioden waarover geschat is lopen van dag 28 tot dag 63 bij $C_{1}$ en van dag 70 tot dag 105 bij de behandelingsniveaux $C_{2}, R, S$ en $I$. Voor de symbolen zie Tabel 5 . Zie ook de regressiecurven in Fig. 5.

The reaction of the leaf area to disease treatment is given in Fig. 5 and Table 8. Only turgescent leaves were measured. The leaf area measured includes the infected areas of turgescent leaves, and excludes leaves killed by pathogens or dead of senescence. The rapid decline of leaf area in $I$ is conspicuous. The leaf areas in $R$ and $S$ differed but slightly. The stems in $S$ and I were c. $0.15 \mathrm{~m}$ shorter than those in $\mathrm{R}$ and $\mathrm{C}$; the stem weights were correspondingly lower. Root deterioration was rapid in I.

Transpiration. After inoculation, the transpiration in $\mathrm{R}$ was higher than in $\mathrm{C}$, but the transpiration in S was less than in C (Fig. 6a and 6b). The transpiration rate in I initially equalled that in $\mathrm{R}$, but later it decreased rapidly. In the end, transpiration in I was lower than in S.

Rust in $R$ and $I$. The first open pustules were seen on the leaves in I 4.5 days after inoculation, one day earlier than in R. Telia on the sheaths were found after c. 32 days in $I$ and $R$. The first open uredosorus on the stem between flag leaf and head was 
Fig. 6. Mean transpiration [kg.plant ${ }^{-1}$ ] in $\mathrm{C}, \mathrm{R}, \mathrm{S}$, and I versus time [day]: a - in the period from inoculation to harvest; $b$ - enlarged detail from day 68 to day 78. For dots and lines see Fig. 4. Parameters of the regression curves are given in Table 9.
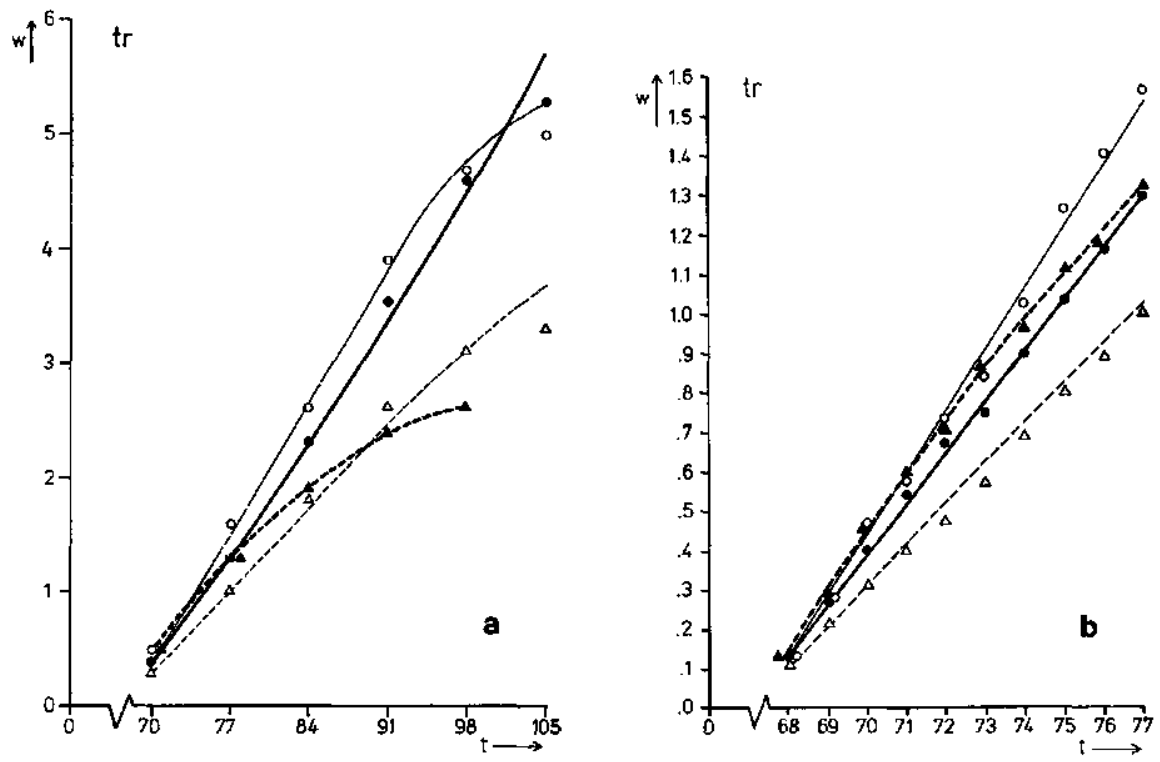

Fig. 6. Gemiddelde transpiratie [kg.plant $\left.{ }^{-1}\right]$ bij $C, R$, $S$ en I tegen de tijd [dag]: $a-i n$ de periode vanaf de inoculatie tot de oogst; $b$ - detail van dag 68 tot dag 78. Voor de punten en lijnen zie Fig. 4. De parameters van de regressiecurven staan in Tabel 9.

Table 9. Parameter values estimated by calculating the regression of transpiration [kg. plant ${ }^{-1}$ ] on time [day], using the regression equation $y=a+b e^{c(x-67)}$. For explanation of the symbols see Table 5. For regression curves see Fig. 6.

\begin{tabular}{lrrr} 
& \multicolumn{1}{c}{$\mathrm{a}$} & \multicolumn{1}{c}{$\mathrm{b}$} & \multicolumn{1}{c}{$\mathrm{c}$} \\
$\mathrm{C}$ & & & \\
$\mathrm{R}$ & -16.08 & 16.09 & 0.008 \\
$\mathrm{~S}$ & 76.20 & -76.23 & -0.002 \\
$\mathrm{I}$ & 16.48 & -16.48 & -0.007 \\
\hline
\end{tabular}

Tabel 9. Parameterwaarden geschat door middel van de berekening van de regressie van de transpiratie $\left[\mathrm{kg}^{\left.\mathrm{p} p l a n \mathrm{t}^{-1}\right]}\right.$ op de tijd [dag], met behulp van de regressievergelijking $y=a+b e^{\mathrm{c}(\mathrm{x}-67)}$. Voor de symbolen zie Tabel 5. Zie ook de regressiecurven in Fig. 6.

found 39 days after inoculation, when yellowing of the heads began. The percentage of infection by the rust in $R$ and $I$ is shown in Fig. 7. The increase in infection was not due to re-infection but to secondary pustules. In the linear phase of the curve, the difference in the rate of increase between $R$ and $I$ is obvious, the rate of increase in $I$ being lower than in $\mathrm{R}$. In I, brown rings were observed round the rust pustules, six days after inoculation with glume blotch. Sporulation of the rust came to a stop within a week. Telia of the rust appeared one week earlier than in R. On day 68 the plants were dead. No rust appeared on the heads in either treatment. 


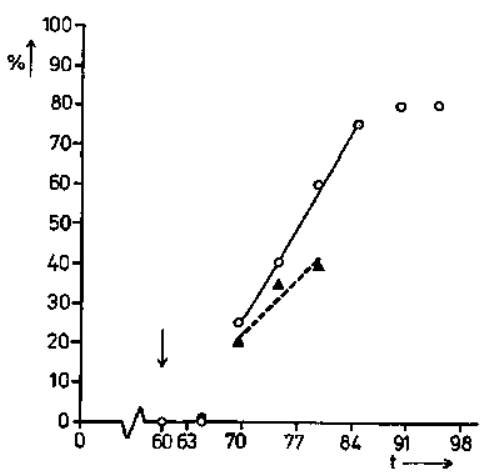

Fig. 7. Mean percentage of infection by rust versus time [day] in $R$ and $\mathbf{l} . \mathrm{O}-=\mathrm{R}, \Delta \ldots=\mathrm{I}, \downarrow=$ time of inoculation. For the parameters of the regression lines see Table 10.

Fig. 7. Gemiddeld aantastingspercentage van de roest tegen de tijd [dag] bij R en I. O- =R, $\Delta-. \cdot=I, \downarrow=$ inoculatietijdstip. De parameters van de regressielijnen staan in Tabel 10.

Table 10. Parameter values estimated by calculating the regression of the percentage of infection on time in the nearly linear part of the curves, using the regression equation $y=a+b x$. See also the regression lines in Fig. 7 and 8.

$R_{R}=$ rust in disease treatment level $R ; R_{I}=$ rust in disease treatment level $I ; S_{S 1}$ glume blotch in disease treatment level $\mathbf{S}$ on the leaves; $\mathbf{S}_{\mathrm{Sh}}=$ glume blotch in disease treatment level $\mathbf{S}$ on the heads; $S_{11}=$ glume botch in disease treatment level I on the leaves.

\begin{tabular}{lll}
\hline & $\mathrm{a}$ & $\mathrm{b}$ \\
$\mathbf{R}_{\mathrm{R}}$ & -214 & 3.4 \\
$\mathrm{R}_{\mathrm{I}}$ & -118 & 2.0 \\
$\mathrm{~S}_{\mathrm{S}}$ & -265 & 3.9 \\
$\mathrm{~S}_{\mathrm{Sb}}$ & -282 & 4.1 \\
$\mathrm{~S}_{\mathrm{II}}$ & -458 & 7.0 \\
\hline
\end{tabular}

Tabel 10. Parameterwaarden geschat door de berekening van de regressie van het aantastingspercentage op de tijd in het bijna lineaire deel van de curven, met behulp van de regressievergelijking $y=a+b x$. Zie ook de regressielijnen in Fig. 7 en $8 . R_{\mathrm{R}}=$ roest in ziektebehandelingsniveau $R_{;} R_{\mathrm{t}}=$ roest in ziektebehandelingsniveau $I ; S_{\mathrm{s1}}=k a f j e s b r u i n$ in ziektebehandelingsniveau $S$ op het blad; $S_{\mathrm{sh}}=k a f j e s-$ bruin op de aren in $S ; S_{11}=$ kafjesbruin op het blad in $I$.

Glume blotch in $S$ and $I$. Flecks caused by glume blotch were first observed three days after inoculation in I, two days later they appeared in S. The flag leaves showed small dark brown spots, the lower leaves large greyish brown flecks. In $\mathrm{S}$, the first pycnidia were found in the leaves 21 days after inoculation, and two days later also on the heads. At harvest time the nodes in I were sunken, but not in $S$. The increase in percentage of infection of glume blotch in I was greater than in S (Fig. 8). The heads in $S$ showed a percentage of attack comparable to that of the leaves (Fig. 8). The heads in I discoloured so rapidly that no attempt was made to estimate the percentage of infection. The figures give the impression that glume blotch had been more injurious than rust. The number of spores applied per unit leaf area did not differ appreciably, but the heads were infected by glume blotch and not by rust.

\section{Conclusions}

No effect of disease on axial development was found, as could be expected when inoculating at stage 56. Maturation of the plants, especially of those treated with 


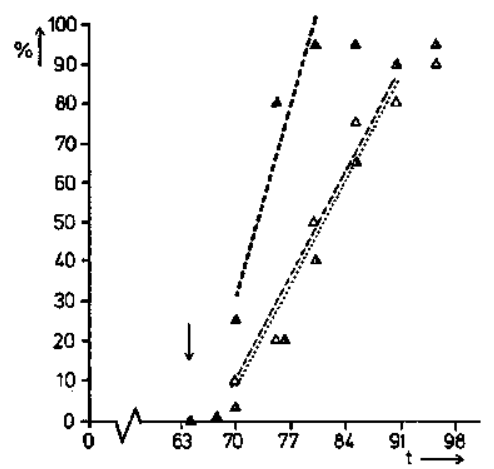

Fig. 8. Mean percentage of infection by glume blotch versus time [day] on leaves $(\triangle-.$.$) and heads (\Delta \ldots .$. in $S$, and on leaves $(\Delta---)$ in I. For the parameters of the regression lines see Table 10.

Fig. 8. Gemiddeld aantastingspercentage ten gevolge van kafjesbruin tegen de tijd [dag] op bladeren $(\Delta--)$ ) en aren $(\Lambda \ldots .$.$) in S$, en op bladeren ( $\triangle . .$.$) in I. De parameters$ van de regressielijnen staan in Tabel 10.

glume blotch (S and I), was accelerated. The effects on growth were mainly observed in the dry weight of the heads. Loss of dry weight of the heads due to rust (R) was not conspicuous; that caused by glume blotch (S) was significant. The effect of both pathogens together (I) on the dry weight of the heads was greater than the sum of the effects of each of the pathogens separately, so that interaction must have occurred. Kernel weight was lower and kernel number was less in I than in C, R and S.

Reduction of turgescent leaf area after inoculation was fast in $I$ and slow in $R$ and $S$; the latter two did not differ in this respect.

Transpiration in $\mathbf{R}$ was greater than in $\mathbf{C}$, in $\mathbf{S}$ smaller than in $\mathbf{C}$. Initially, the transpiration of $I$ was equal to that in $R$, but later the transpiration rate decreased rapidly to a value far below that in S. Glume blotch infection retarded the growth of rust but accelerated the formation of telia. The percentage of infection by glume blotch increased faster after previous rust infection (I) than without (S), on leaves as well as on heads.

\section{Discussion}

The ripening of the uninfected plants in the climate chamber differed from that of a normal crop in the field. At harvest time, the heads were yellow and the kernels were ripe, but the leaves were still green for c. $70 \%$. In all cases, the kernels were shrivelled, also in C. Logistic regression on growth and transpiration of the uninfected plant over the full growth period showed poor fit in this experiment. The semi-logarithmic regressions fitted much better (Fig. 9a and 9b). The value of the regression parameter $c$ (Table 9) for the transpiration of the uninfected plant in the period after infection was low but positive, indicating that the transpiration rate did not decrease in the course of time.

This effect, known in French as 'échaudage', may be related to the temperature profile in the climate chamber. The highest air temperature in the climate chamber was measured near the heads, whereas in the field the highest air temperatures during the day are measured c. $0.25 \mathrm{~m}$ above soil level in a spring wheat crop. The inverted maturation process' (heads first, leaves later) might be described as heat injury.

The conclusions derived from this experiment are summarized in the previous section. The question arises whether they may be generalized, because the magnitude 
Fig. 9a. Mean dry weight $\left[10^{-3} \cdot \mathrm{kg}^{\text {plant }}{ }^{-1}\right]$ versus time [day] in $\mathrm{C}$ over the full growth period. For the parameters of the regression curve see Table 11.

Fig. 9b. Mean transpiration [kg.plant ${ }^{-1}$ ] versus time [day] in $\mathrm{C}$ over the full growth period. For parameters of the regression curve see Table 11.
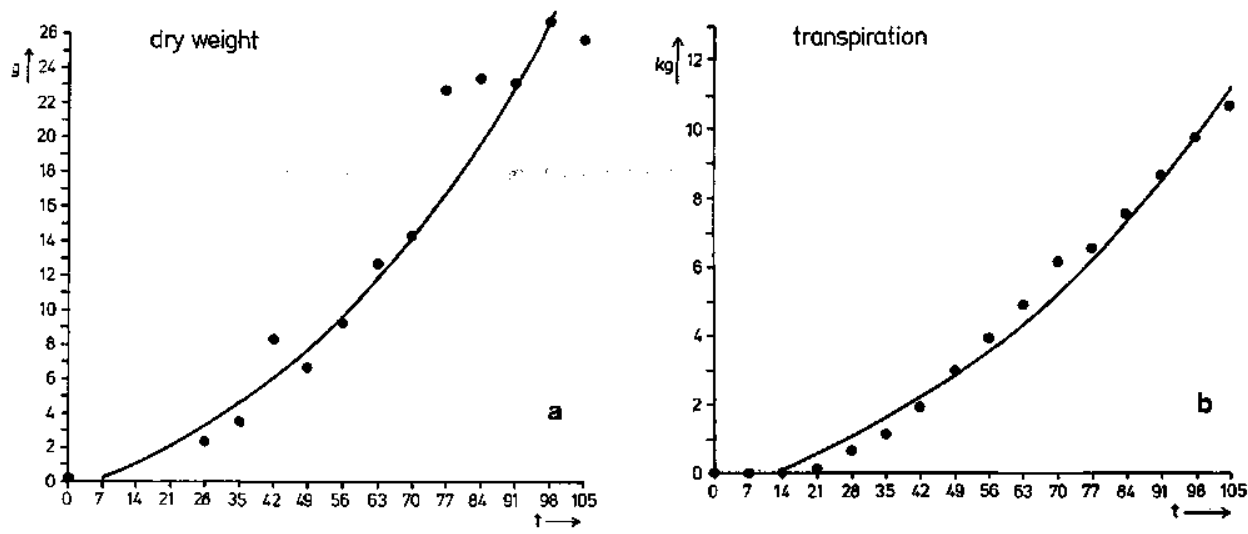

Fig. 9a. Gemiddeld drooggewicht $\left[10^{-3} . \mathrm{kg}_{\text {. plant }}{ }^{-1}\right]$ tegen de tijd $[$ dag $]$ in $C$ over de hele groeiperiode. Zie voor parameters van de regressiecurve Tabel 11.

Fig. 9b. Gemiddeld drooggewicht [kg.plant $\left.{ }^{-1}\right]$ tegen de tijd [dag] in $C$ over de hele groeiperiode. Zie voor parameters van de regressiecurve Tabel 11 .

Table 11. Parameter values estimated by calculating the regression of total dry weight $\left[10^{-3}\right.$. kg.plant ${ }^{-1}$ ] and transpiration [kg.plant ${ }^{-1}$ ] on time [week] in disease treatment level C, using the regression equation $y=a+b e^{e x}$. See the regression curve in Fig. 9.

\begin{tabular}{llll}
\hline & $\mathrm{a}$ & $\mathrm{b}$ & $\mathrm{c}$ \\
dry weight & -7.2 & 6.6 & 0.117 \\
transpiration & -4.1 & 3.5 & 0.098 \\
\hline
\end{tabular}

Table 11. Parameterwaarden geschat door middel van de berekening van de regressie van het totale drooggewicht $\left[10^{-3} . \mathrm{kg}_{\text {.plant }}{ }^{-1}\right]$ en de transpiratie [kg.plant $\left.{ }^{-1}\right]$ op de tijd [week] bij ziektebehandelingsniveau $C$. De gebruikte regressievergelijking heeft de vorm van $y=a+b e^{\mathrm{ex}}$. Zie ook de regressiecurve in Fig. 9.

of the differences between infected and uninfected plants is as much an outcome of the circumstantial factors as of the experimental factors.

\section{Samenvatting}

Een ecofysiologische benadering van 'schade', geillustreerd aan het systeem tarwe, bruine roest en kafjesbruin.

II. De ontwikkeling, groei en transpiratie van ongeinfecteerde planten en planten geinfecteerd met Puccinia recondita f.sp. triticina en/of Septoria nodorum in een klimaatkamerproef.

De proef had tot doel inzicht te verschaffen in het ontstaan van 'schade' door pathogene schimmels bij graangewassen. De infectie verandert in het algemeen de fysiologie van de geïnfecteerde plant. De aard en mate van de verandering hangen vermoedelijk af van de toestand van de plant op het tijdstip van infectie, van de aard en hoeveelheid 
van het infectieuse agens, en van de groei-omstandigheden na de infectie. Als objecten werden gekozen de ongeïnfecteerde tarweplant (C), de plant geïnfecteerd met alleen $P$. recondita $(\mathrm{R})$, die met alleen $S$. nodorum $(\mathrm{S})$, en de tarweplant geïnfecteerd met beide pathogenen (I). Voor de beschrijving van de 'fysiologie' van de plant werden gekozen: de ontwikkeling, groei en transpiratie. De axiale ontwikkeling is beschreven volgens Schoute (1910) en het ontwikkelingsstadium volgens Zadoks et al. (1974). De groei is beschreven aan het droge-stofgewicht van de plant als geheel en dat van wortels, spruit, blad, halmen, aren en korrels, terwijl ook het aantal korrels en het bladoppervlak bepaald werden. Deze proef behoort tot de klasse 'single input multiple output experiments' (Zadoks, 1972). De enige variabele die op meer dan één niveau voorkomt is de variabele 'ziekte-behandeling' met vier niveaus: C, R, S en I). Alle overige variabelen zijn 'situatiefactoren', waarvan een beschrijving gegeven wordt.

De inoculaties werden per pathogeen slechts eenmaal in de groeicyclus van de tarweplant gedaan, terwijl herinfectie werd uitgesloten. De roestinoculatie vond plaats 60 dagen na het planten in ontwikkelingsstadium 56, vier dagen later volgde de inoculatie met Septoria. De axiale ontwikkeling van de plant werd niet beinvloed. Wel volgden de ontwikkelingsstadia elkaar sneller op bij de zieke planten. De groei werd duidelijk beïnvloed. Het verlies aan drooggewicht van de aren was niet opvallend in $R$, wel in S. Het effect van beide pathogenen samen in I op het verlies van aargewicht was groter dan de som van de effecten van elk van de pathogenen afzonderlijk; dit is een aanwijzing voor het bestaan van interactie. In I was het korrelgewicht lager en het aantal korrels kleiner dan in C, $R$ en $S$ (Fig. 4, Tabel 6).

De vermindering van turgescent bladoppervlak na inoculatie verliep snel in I, minder snel in $\mathbf{R}$ en $\mathbf{S}$. De vermindering van het turgescente bladoppervlak in $\mathbf{R}$ en $\mathbf{S}$ verschilde onderling niet. De transpiratie in $\mathbf{R}$ was groter, die in $\mathbf{S}$ kleiner dan in $\mathbf{C}$. Aanvankelijk was de transpiratiesnelheid in I gelijk aan die in R, maar later nam de transpiratiesnelheid sterk af. Uiteindelijk was de transpiratie in I veel geringer dan in $S$ (Fig. 6, Tabel 9). De toeneming van het aantastingspercentage door de roest was in I geringer dan in R (Fig. 7). De roestsporulatie in I hield spoedig na het zichtbaar worden van de kafjesbruinsymptomen op. De toeneming van het aantastingspercentage door Septoria in I was groter dan die in S, zowel op het blad als op de aar (Fig. 8).

\section{Acknowledgments}

The authors are indebted to Dr K. Schurer (Technical and Physical Engineering Service TFDL, Wageningen) for advice on the measurement of climatic factors and leaf temperatures. Mr A. H. Gerritsen (Technical Service, Crop Protection Department) has shown great interest, and his assistance in the operation of the climate chamber is highly appreciated. Miss C. F. Geerds' help with the analytical work is gratefully mentioned. The services of the drawing office, secretariat, and library of the Crop Protection Departments, and the service rendered by the University Computer Centre are much appreciated. Mr H. J. A. van Beckum's correction of the English text are gratefully mentioned. Mr H. Bakker (Animal Husbandry Department) provided the computer programme for the logistic curve regression. Professor L. C. A. Corsten (Mathematics Department) suggested the method used in testing for differences between levels of disease treatment. The continuous interest in the progress of the work shown by Dr J. C. Zadoks has been stimulating. 


\section{References}

ASHS Committee on Growth Chamber Environments, 1972. Guidelines for reporting studies conducted in controlled environment chambers. Hortscience 7,3, section 1, p. 239.

Eyal, Z., Clifford, B. C. \& Caldwell, R. M., 1968. A settling tower for quantitative inoculation of leaf blades of mature small grain plants with urediospores. Phytopathology 58: 530-531.

James, W. C., 1971. A manual of assessment keys for plant diseases. Publ. Can. Dep. Agric. No. 1458.

Loegering, W. Q., McKinney, H. H., Harmon, D. L. \& Clark, W. A., 1961. A Iong term experiment for preservation of urediospores of Puccinia graminis tritici in liquid nitrogen. PI. Dis. Reptr 45: 384-385.

Nair, K. R., 1954. The fitting of growth curves. In: D. Kempthorne, T. A. Bancroft, J. W. Gowen \& J. L. Lush (Ed.), Statistics and Mathematics in biology. Iowa State College Press, Ames, Iowa: 119-132.

Schoute, J. C., 1910. Die Bestockung des Getreides. Verh. Kon. Akad. Wet., Amsterdam, sect. 2, 15 (2), $491 \mathrm{pp}$.

Schurer, K., 1972. Dynamisch gedrag en stralingsfout van meetvoelers voor meting van klimaatgrootheden. Meded. Tech. en fys. Dienst Landb. TFDL No. 13:34-40.

Stoutjesdijk, Ph., 1966. On the measurement of radiant temperature of vegetation surfaces and leaves. Wentia 15: 191-202.

Tegelaar, P. \& Wal, A. F. van der, 1974. An ecophysiological approach to crop losses exemplified in the system wheat, leaf rust and glume blotch. I. A simple and accurate balance for the continuous measuring and recording of (evapo-) transpiration of plants in indoor experiments. Neth. J. PI. Path. 80: 77-84.

Wal, A. F. van der, Shearer, B. L. \& Zadoks, J. C., 1970. Interaction between Puccinia recondita f. sp. triticina and Septoria nodorum on wheat, and its effects on yield. Neth. J. Pl. Path. 76: 261-263.

Wassink, E. C. \& Scheer, C. van der, 1951. A spherical radiation meter. Meded. LandbHoogesch. Wageningen $51: 175-183$.

Zadoks, J. C., 1972. Methodology of epidemiological research. A. Rev. Phytopath. 10: 253-276.

Zadoks, J. C., Chang, T. T. \& Konzak, C. F., 1974. A decimal code for the growth stages of cereals. Eucarpia Bull. 7:10 pp.

\section{Addresses}

Laboratorium voor Fytopathologie, Landbouwhogeschool, Binnenhaven 9, Wageningen, the Netherlands. 


\title{
An ecophysiological approach to crop losses exemplified in the system wheat, leaf rust and glume blotch ${ }^{1}$
}

\section{Effects of soil-water potential on development, growth, transpiration, symptoms, and spore production of leaf rust-infected wheat}

\author{
A. F. VAN DER WAL, HANNEKE SMEITINK and G. C. MAAN
}

Accepted 8 July 1974

Laboratory of Phytopathology, Agricultural University, Wageningen

\begin{abstract}
Uninfected plants of spring wheat 'Kolibri' and plants infected with leaf rust were grown in a climate chamber at three soil-water potentials: $-1025 \mathrm{~J} . \mathrm{kg}^{-1}$ (D, 'dry', near wilting point), $-425 \mathrm{~J}^{\mathrm{kg}} \mathbf{k}^{-1}$ (M, 'medium', intermediate), and $-250 \mathrm{~J} . \mathrm{kg}^{-1}$ (W, 'wet', near saturation point). At lower water potentials plant development was faster, growth rate lower, and transpiration less than at higher water potentials. Growth and transpiration of plants at $\mathbf{W}$ were approximately twice those at $\mathrm{D}$. Plants at $M$ showed an intermediate response. Growth and yield of rusted plants grown at $\mathbf{M}$ were only slightly less than those of the uninfected controls, whereas at $\mathrm{D}$ and $\mathrm{W}$ considerable losses of plant dry weight and yield were caused by the rust. Infection type, pustule size and spore production were related to soil-water potential; at $\mathbf{M}$, the pustules were smallest and the spore production was minimal. Results show a marked effect of soil-water potential on plant morphogenesis, and indicate that resistance of 'Kolibri' to leaf rust was related to soil-water potential. Optimal resistance was found at $\mathbf{M}$, the intermediate soil-water potential.
\end{abstract}

\section{Introduction}

Water moves from the soil through the plant into the atmosphere along gradients of water potential (Boyer, 1969). Since gradients of water potential may effect plants in health and disease, a climate chamber experiment was carried out to study the effects of soil-water potential on the healthy and the rusted wheat plant (Triticum aestivum L.). Only one cultivar, the spring wheat 'Kolibri', was used. Uninfected plants and plants infected with rust were grown at three different water potentials. In the previous paper, the experimental factor was 'disease treatment', represented by four levels: uninfected, leaf rust, glume blotch, and leaf rust + glume blotch. Introduction of a further experimental factor, viz. soil-water potential, necessitated a reduction of

1 I. A simple and accurate balance for the continuous measuring and recording of (evapo-) transpiration of plants in indoor experiments. P. Tegelaar and A. F. van der Wal, Neth. J. PI. Path. 80 (1974): $77-84$.

II. Development, growth, and transpiration of uninfected plants and plants infected with Puccinia recondita f.sp. triticina and/or Septoria nodorum in a climate chamber experiment. A. F. van der Wal and M. C. Cowan, Neth. J. Pl. Path. 80 (1974): 192-214. 
the number of levels of the factor 'disease treatment' in view of the limitations imposed by the available space and manpower. The use of rust in the present experiment was based on the observation that the transpiration rate of the rusted plant increased, at least during a certain period after infection. This increase is of interest since it may affect photosynthesis and other processes under conditions of 'water stress'.

Effects of rust infection on transpiration were reported before (e.g. Weiss, 1924; Johnston and Miller, 1940). In this early work essential elements in the description of environment, plant, or pathogen are missing (Gates, 1968). Here, due attention is payed to the description of environment, plant, and pathogen, with the aim to provide a starting point for analytical studies. Cowan and Zadoks (1973) demonstrated the effect of soil-water potential on transpiration of uninfected and rusted wheat seedlings, and on uredospore production. Van der Wal and Cowan (1974) presumed that the condition of the plant, its 'state', at inoculation time had a decisive effect on subsequent disease development. Differences in morphological development between plants of the same age and cultivar reflect differences in 'state'. By changing soil-water potential in an otherwise identical environment, various water potential differences between soil and air are applied to which plant development and growth can respond. The present experiment was performed to find out whether the 'state' of the plant at infection time affects loss. The wheat plants were observed during the full growth period. No effort was made to relate morphological and physiological differences between plants from various treatments to possible biochemical differences.

\section{Methodology}

Terminology in this paper is similar to that used by Van der Wal and Cowan (1974), where the experimental design, variables, responses, statistical methods, materials and techniques (e.g. a detailed description of the conditions in the climate chamber), inoculation techniques, and methods of measuring development, growth, and transpiration as applied in the present experiment are described.

Experimental factors. Disease treatment is applied at two levels, viz. C (uninfected plant) and R (plant infected with rust, Puccinia recondita (Rob. ex Desm.) f. sp. triticina Eriks. Water potential, a situational factor in the previous experiment, is introduced here as the second experimental factor at three levels: $-1025 \mathrm{~J}_{\mathrm{kg}} \mathrm{k}^{-1}$ (D, 'dry', near wilting point), $-425 \mathrm{~J} . \mathrm{kg}^{-1}$ (M, 'medium', intermediate), and $250 \mathrm{~J} . \mathrm{kg}^{-1}$ (W, 'wet', near saturation).

Experimental design and sampling. On each sampling date, all six plants of a sample were taken from one bucket. Consequently, the 'bucket effect' is confounded with the 'sampling time effect'. Successive sampling was done for dry weight and leaf area determination, usually with weekly intervals, but in the second half of the growth period, as it became apparent that the development proceeded more slowly than expected, the sampling intervals had to be extended to save plants for the final sampling.

Responses. The developmental stage of the plants was recorded weekly. Axial development was indicated by the number of stems per plant, a stem considered here as an 
axis with at least one node. The number of heads per plant was counted. Dry weight of roots, stems, leaves, and heads was determined and expressed in units of weight per plant. Area of leaves, turgescent enough for a fair measurement, and transpiration were measured as in the previous experiment. Kernel number and kernel weight were determined only in the final samples at each of the three water potential levels. The percentage of infection was determined as the percentage leaf area disrupted by the sporulating surface of the pustules. Figures for percentage of infection are therefore considerably lower than in the previous paper, although identical inoculum densities were used. In addition, pustule size and spore production were measured. Pustule size was measured according to Mehta and Zadoks (1970).

Materials and techniques. After pregermination, the seedlings were planted in soil with a water potential of c. $-400 \mathrm{~J} . \mathrm{kg}^{-1}$. Between day 15 and day 25 , the soil-water potentials were gradually adjusted to the values desired. No wilting was observed during or after the adjustment period.

Inoculation was carried out on day 42 , when the plants at D had the development stage 37 (Table 1), with the flag leaves just unfolded. Plants at $M$ and $W$ developed more slowly, but they had a greater leaf area than the plants at D (Fig. 2). Half the number of buckets with plants at each water potential level was inoculated. The spore density was c. 20 spores per $\mathrm{mm}^{2}$. Unfortunately, the effect of water potential on the development of the plants was greater than expected. The plants at $\mathbf{M}$ and $\mathbf{W}$ 'outgrew' their infection. The aim was to have almost equally infected plants at all water potential levels. Plants at $M$ were inoculated again in stage 60 , on day 66 , and plants at $W$ in stage 58 , on day 73 . Spore density was c. 10 spores per $\mathrm{mm}^{2}$, half the density used at the first inoculation, to compensate for the spores already on the leaves due to cross inoculation by rusted neighbour plants. In all inoculations c. $90 \%$ of the spores germinated.

To collect the spores produced by the inoculated plants, a cuff of smooth cardboard was placed around the six plants of a bucket. Its upper diameter was large enough to intercept all spores falling from the leaves. Its lower diameter fitted close round the stem bases of the plants. At the lower end of the cuff, the cardboard was folded upwards to hold the spores falling from the leaves on the cuff. Before sampling, the rusted leaves were tapped gently, and the ripe spores fell on the cuff. The spores on the cuff were collected by means of a cyclone collector (Mehta and Zadoks, 1970).

\section{Results}

Development. The developmental stages of the plants are given in Table 1. On day 35,20 days after the day on which the soil-water potentials began to diverge, the effect of soil-water potential on developmental stage became visible. The plants at $D$ developed rapidly, those at $W$ were slow in this respect, and plants at $M$ were intermediate. The number of stems per plant was determined from day 42 until harvest. An analysis of variance applied to stem numbers yields a clear water potential effect ( $\mathrm{p}<\mathbf{0 . 0 1}$ ), but no effect of time. The average number of stems per plant developed at $\mathrm{D}$ was 6.6, at $\mathrm{M} 8.5$, and at $\mathrm{W} 9.5$. The number of heads per plant was determined from day 56 onwards to harvest. The effects of time and water potential are both significant $(\mathrm{p}<0.01)$. The earliest heading appeared in $\mathrm{D}$; on day $56,2.4$ heads per 
Table 1. Development stages of the uninfected plant $(C)$ with time $(t)$ in days after planting at the water potentials $-1025 \mathrm{~J} . \mathrm{kg}^{-1}$ (D), $-425 \mathrm{~J} . \mathrm{kg}^{-1}(\mathrm{M})$, and $-250 \mathrm{~J}_{\mathrm{kg}} \mathrm{g}^{-1}$ (W). The development is expressed in the decimal scale by Zadoks et al. (1974). A * means no observation.

\begin{tabular}{lllllllllllllll}
\hline $\mathbf{t}$ & 0 & 7 & 14 & 28 & 35 & 42 & 49 & 56 & 63 & 70 & 84 & 98 & 105 & 112 \\
D & & & & 27 & 31 & 37 & 50 & 58 & 64 & 73 & 85 & 92 & & \\
M & 07 & 13 & 22 & 27 & 30 & 32 & 39 & 56 & 60 & 71 & 77 & $*$ & 92 & \\
W & & & & 27 & 30 & 32 & 37 & 43 & 52 & 58 & 73 & $*$ & $*$ & 92 \\
\hline
\end{tabular}

Tabel 1. Ontwikkelingsstadia yan de niet-geinfecteerde plant $(C)$ in de loop van de tijd $(t)$ in dagen na het planten, bij de waterpotentialen $-1025 \mathrm{~J} . \mathrm{kg}^{-1}(D),-425 \mathrm{~J} . \mathrm{kg}^{-1}(\mathrm{M})$ en $-250 \mathrm{~J} \cdot \mathrm{kg}^{-1}(W)$. De ontwikkeling is aangeduid met behulp van de decimale schaal van Zadoks et al. (1974). Een * betekent geen waarneming.

plant were visible, at harvest 6.3. At M 0.8 heads per plant were visible on day 56 , but at harvest time there were 8.0 heads. At $W$ the first heads were seen on day 63 , whereas at harvest time 8.4 heads per plant were counted. Disease had no significant effect on the number of heads $(p<0.05)$. The number of stems was not tested for disease effect, because of lack of data.

Fig. 1. Mean dry weight per plant (w) $\left[10^{-3} \cdot \mathrm{kg}^{\text {plant }}{ }^{-1}\right]$ in $C$ and $R$ at $D, M$ and $W$, versus time (t) [day] from day 28 to day 112. Symbols as in Table $2 ; . \ldots=C_{W}, \square \ldots=R_{W}, \Delta \ldots=C_{M}, \Delta \ldots=$ $\mathbf{R}_{\mathrm{M}}, \bullet-=\mathrm{C}_{\mathrm{D}}, \mathrm{O}-=\mathbf{R}_{\mathrm{D}}$. For the parameters of the regression curves see Table 4 .
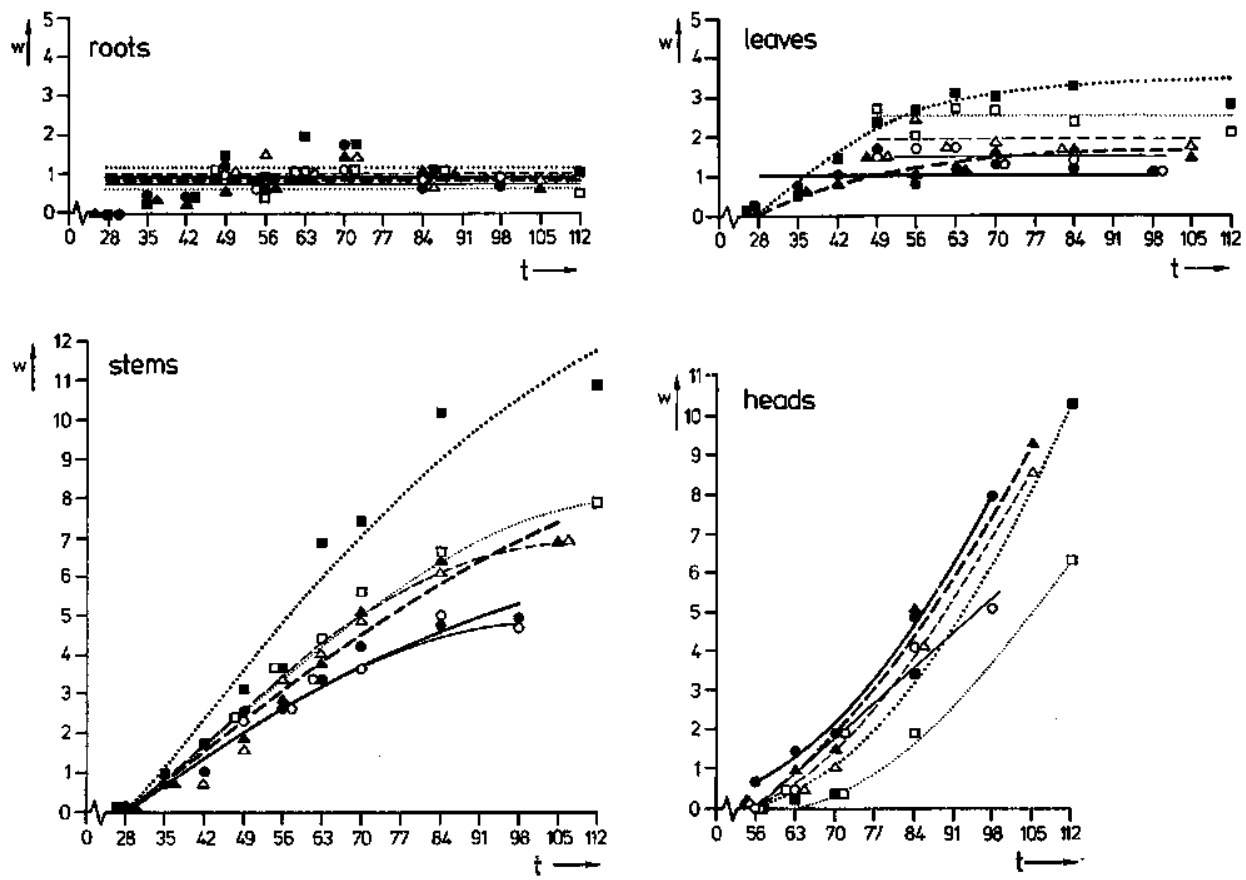

Fig. 1. Gemiddeld drooggewicht per plant (w) $\left[10^{-3} . \mathrm{kg}_{\text {.plant }}{ }^{-1}\right]$ in $C$ en $R$ bij $D, M$ en $W$, tegen de tijd (t) [dag] van dag 28 tot dag 112. Het gebruik van de symbolen is als aangegeven in Tabel $2 ; \square \ldots=C_{\mathrm{w}}$, $\square \ldots=R_{\mathrm{w}}, \Delta \cdots=C_{\mathrm{M}}, \Delta \cdots=R_{\mathrm{M}}, \bullet-=C_{\mathrm{D}}, \mathrm{O}-=R_{\mathrm{D}}$. Voor de parameters van de regressiecurven zie Tabel 4. 
Table 2. Student's t-test has been applied to test the significance of the differences between disease treatment and water potential levels. For $C-R$ at $D, M$, and $W$ and for the combinations $C_{W}-C_{M}$, $C_{W}-C_{D}$, and $C_{M}-C_{D}$, the regression of the difference between two concomitant values $\left(y_{t}\right)$ per observation day $\left(x_{1}\right)$ versus time $(x)$ was calculated, using the regression equation $y_{1}=a+b x_{1}$. The $t$-values of the regression constants (a) and the regression coefficients (b) are tabulated in order to give an idea about the 'noise' in these data. There are n-2 $=4$ degrees of freedom for $t$-tests of roots, leaves, stems and leaf area in the $C-R$ combinations, and 7 for $C_{W}-C_{M}, C_{W}-C_{D}$ and $C_{M}-C_{D}$. There were only 3 degrees of freedom for tests of heads in all combinations.

Symbols: $C=$ uninfected plant; $R=$ plant infected with rust: $C_{D}, C_{M}$ and $C_{W}=$ uninfected plants grown at $\mathrm{D}, \mathrm{M}$, and $\mathrm{W}$ (waterpotential levels, Table 1); roots = dry weight of roots per plant; leaves $=$ dry weight of leaves per plant; stems = dry weight of stems per plant; heads = dry weight of heads per plant; leaf area = leaf area per plant.

\begin{tabular}{|c|c|c|c|c|c|c|c|c|c|c|c|c|}
\hline & \multicolumn{2}{|c|}{ Roots } & \multicolumn{2}{|c|}{ Leaves } & \multicolumn{2}{|c|}{ Stems } & \multicolumn{2}{|c|}{ Heads } & \multicolumn{2}{|c|}{ Leaf area } & \multicolumn{2}{|c|}{ Transpiration } \\
\hline & a & b & a & b & a & b & a & b & a & b & a & b \\
\hline (C-R) & 0.29 & 0.04 & -1.37 & 0.66 & 0.36 & 0.18 & -0.32 & 1.94 & -1.34 & 1.69 & -5.81 & 5.02 \\
\hline$(C-R)_{M}$ & -1.86 & 1.44 & -1.02 & 0.39 & -0.70 & 0.76 & 1.06 & 1.15 & -0.23 & 0.10 & -0.58 & 3.43 \\
\hline$(C-R)_{w}$ & 1.10 & 0.28 & -0.11 & 1.95 & 0.96 & 2.38 & -2.51 & 7.42 & 0.97 & 0.26 & -18.10 & 10.00 \\
\hline $\mathrm{C}_{W}-\mathrm{C}_{M}$ & 0.32 & 0.16 & 0.09 & 3.40 & -1.58 & 7.31 & -1.28 & 0.85 & 0.76 & 1.42 & 13.37 & 5.02 \\
\hline$C_{W}-C_{D}$ & -0.19 & 0.43 & -0.42 & 4.18 & -3.10 & 9.23 & -2.08 & 2.02 & 0.73 & 1.69 & -4.41 & 18.81 \\
\hline$C_{M}-C_{D}$ & -1.07 & 0.63 & -1.38 & 3.00 & -3.02 & 5.37 & -5.83 & 7.83 & -0.26 & 2.34 & -2.61 & 7.59 \\
\hline
\end{tabular}

Tabel 2. De t-toets van Student is gebruikt om de verschillen te toetsen tussen ziektebehandelingsniveaus en niveaus van waterpotentiaal. Voor de combinaties $C-R$ bij $D, M$ en $W$ en voor $C_{W}-C_{M}, C_{W}-C_{\mathrm{D}}, C_{\mathrm{M}}-C_{\mathrm{D}}$, werd de regressie berekend van het verschil van twee bijeengevoegde waarden $\left(y_{\mathrm{i}}\right)$ per waarnemingsdag $\left(x_{i}\right)$ tegen de tijd $(x)$, middels de regressievergelijking $y_{i}=a+b x_{i}$. De $t$-waarden van de regressieconstanten ( $a$ ) en de regressiecoëfficienten (b) zijn vermeld met het doel een indruk te geven van de 'ruis' in deze waarnemingen. Er zïn $n-2=4$ vrijheidsgraden voor de t-toets van roots, leaves, stems en leaf area in de $C-R$ combinaties, en 7 voor die in $\mathrm{C}_{W}-\mathrm{C}_{M}, \mathrm{C}_{W}-\mathrm{C}_{\mathrm{D}}, \mathrm{C}_{\mathrm{M}}-\mathrm{C}_{\mathrm{D}}$. In alle combinaties waren er slechts 3 vrijheidsgraden voor de toetsen van heads.

Symbolen: $C=$ niet geinfecteerde plant $; R=$ plant geinfecteerde met roest $; C_{\mathrm{D}}, C_{\mathrm{M}}$ en $C_{\mathrm{W}}=$ niet geinfecteerde planten opgegroeid bij waterpotentiaal $D, M$ en $W($ Tabel 1$)$; roots $=$ drooggewicht van de wortels per plant; leaves $=$ drooggewicht van de bladeren per plant; stems $=$ drooggewicht van de stengels per plant; heads $=$ drooggewicht van de aren per plant; leaf area $=$ bladoppervlak per plant.

Growth. The results of measurements are given in Fig. 1. To test the significance of the differences between curves the 'difference method' described in Van der Wal and Cowan (1974) was used (Table 2). Six combinations of levels of disease treatment and water potential were studied for each response: $(C-R)$ at $D, M$, and $W$; and $C_{W}-C_{M}$, $C_{W}-C_{D}$, and $C_{M}-C_{D}$. The decisions regarding significance of the effects are summarized in Table 3. The parameter values obtained after the application of various regression models on the data, are given in Table 4 together with the models used.

There was no effect of disease treatment, time, or water potential on root weight during the period from day 28 to harvest. The regression coefficients $b$ (Table 3 ) did not differ significantly from zero. The absence of effects is possibly due to the inadequacy of the technique of root weight determination.

Time and water potential clearly affected dry weight of leaves per plant (Table 2 and 3). The weight of leaves per plant at $W$ was twice that at $D$. No effect of disease could be shown.

For dry weights of stems, time and water potential effects were found. At $\mathbf{D}$ and $\mathbf{M}$, final dry weights of stems were 5 and $7 \mathrm{~g}$ per plant respectively, but there was no 
Table 3. The decisions about the significance of the differences between responses in the disease treatment and water potential combinations listed in Table 2. For symbols see Table $2 . \mathrm{A}+$ indicates significance, $a-$ no significance at $P \leqslant 0.10$ (two tailed). The decisions are based on Student's t-values

\begin{tabular}{|c|c|c|c|c|c|c|c|c|c|c|c|c|}
\hline & \multicolumn{2}{|c|}{ Roots } & \multicolumn{2}{|c|}{ Leaves } & \multicolumn{2}{|c|}{ Stems } & \multicolumn{2}{|c|}{ Heads } & \multicolumn{2}{|c|}{ Leaf area } & \multicolumn{2}{|c|}{ Transpiration } \\
\hline & a & $b$ & $a$ & $\mathrm{~b}$ & a & b & a & $\mathbf{b}$ & a & b & a & $b$ \\
\hline$(C-R)_{D}$ & - & - & - & - & - & - & - & - & - & - & + & + \\
\hline$(C-R)_{M}$ & - & - & - & - & - & - & - & - & - & - & - & + \\
\hline$(C-R)_{w}$ & - & - & - & - & - & + & + & + & - & - & + & + \\
\hline $\mathrm{C}_{\mathrm{W}}-\mathrm{C}_{\mathrm{M}}$ & - & - & - & + & - & + & - & - & - & - & + & + \\
\hline$C_{w}-C_{D}$ & - & - & - & + & + & + & - & - & - & - & + & + \\
\hline$C_{M}-C_{D}$ & - & - & - & + & + & + & + & + & - & + & + & + \\
\hline
\end{tabular}

Tabel 3. Beslissingen over de significantie van de verschillen tussen responsies bij de niveaus van ziektebehandeling en waterpotentiaal vermeld in Tabel 2 . Voor de symbolen zie Tabel 2 . Een + betekent significantie, een - geen significantie bij $P \leqslant 0.10$ (tweezijdig). De beslissingen berusten Student's $t$-waarden.

disease effect. In $\mathrm{W}$, however, the effect of disease treatment was evident, final stem dry weights of $C$ and $R$ being 11 and $8 \mathrm{~g}$ per plant respectively.

Differences between curves of head dry weight were only found for $(\mathbf{C}-\mathbf{R})_{\mathrm{w}}$, and for $C_{M}-C_{D}$ (Table 3). Analysis of variance applied to the yield data showed significant effects of disease and water potential $(p<0.01)$ on kernel number and kernel weight per plant (Table 7). In addition, an interaction of disease and water potential was demonstrable $(p<0.05)$. Kernel weight at $M$ was only slightly reduced by rust infection $(9 \%$ ), whereas at $\mathrm{D}$ and $\mathrm{W}$ it was seriously reduced (c. $40 \%$ ). At $\mathrm{M}$, no reduction in kernel number was observed, but at $\mathrm{D}$ and $\mathrm{W}$, the kernel number was severely reduced after rust infection (c. 30\%). Average kernel weight was reduced by rust, most seriously in $R_{\mathrm{W}}$. Fig. 2 shows the leaf area per plant versus time at the three water potential levels. The application of the 'difference method' on the data yielded only significance of the difference between $C_{M}$ and $C_{D}$ (Table 3 ). At $D$, the plants developed only c. $40 \%$ of the leaf area of plants at W. The effect of disease on turgescent leaf area is evident at $\mathrm{W}$, but is hardly visible in $\mathrm{M}$ and $\mathrm{D}$. The absence of significance of differences may be attributed to the segment of the curves compared.

Transpiration. At D, transpiration by C was only c. $40 \%$ of that at W (Fig. 3a); at $M$, it was c. $60 \%$. The effects of disease varied with the water potential applied. At $D$, transpiration by $\mathbf{R}$ was less than that by $\mathbf{C}$ (Fig. 3b, Table 3), the period between day 49 and day 77 excepted. The result was a lower transpiration figure at harvest time. At $M$, the transpiration rate of $R$ was greater than that of $C$ during the whole period following infection. At $\mathrm{W}$, the transpiration of $\mathrm{C}$ was higher than that of $\mathrm{R}$, a short period after inoculation excepted. At harvest time the difference was c. $9 \%$.

Infection type. The infection types varied with soil-water potential. Seven days after inoculation, type 3 was observed on flag leaves at $D$ and $W$, type 2 at $M$. Some 14 days after inoculation the infection type at $\mathrm{D}$ changed to 4 and stayed at that level until ripening. At $\mathrm{W}$ the scores changed to 4 about 1 month after inoculation, but later type 3 was seen again. Seven days after inoculation type 2 was observed on plant at

Neth. J. Pl. Path. 81 (1975) 
Fig. 2. Mean turgescent leaf area (la) $\left[10^{-2} \cdot \mathrm{m}^{2} \cdot\right.$ plant $\left.^{-1}\right]$ versus time [day] in $\mathrm{C}$ and $\mathbf{R}$ at $\mathbf{D}, \mathbf{M}$, and W. Symbols as in Fig. 1. The shape and position of the lines were obtained by eye-fitting.

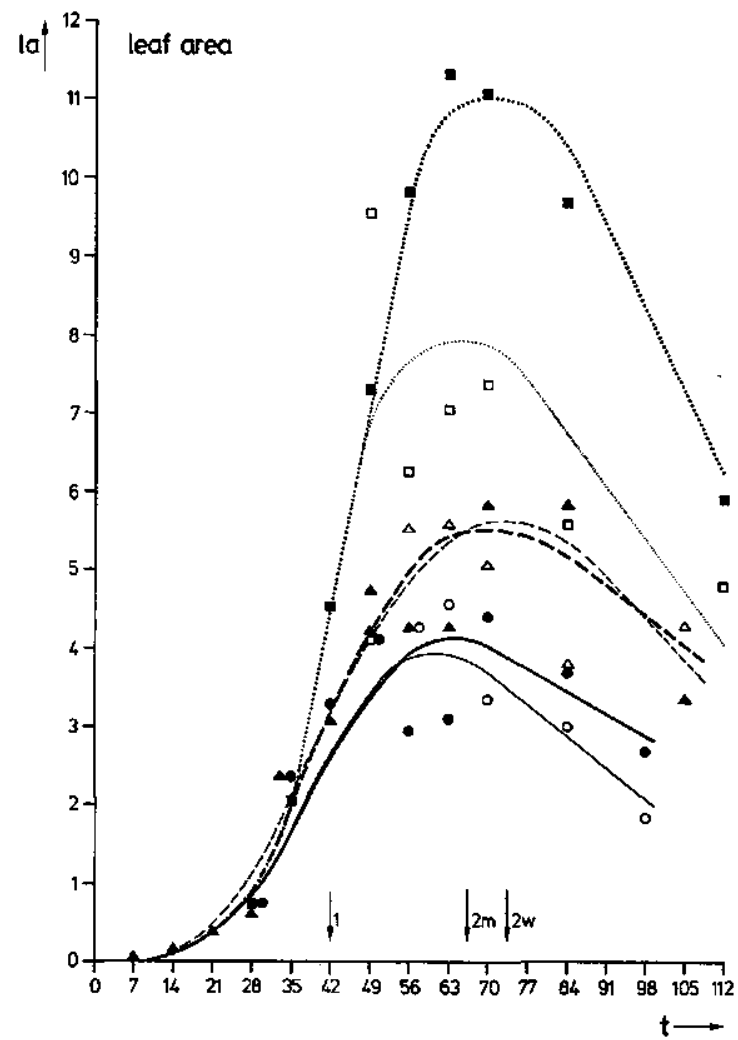

Fig. 2. Gemiddeld turgescent bladoppervlak (la) $\left[10^{-2} \cdot \mathrm{m}^{2}\right.$. plant $\left.{ }^{-1}\right]$ tegen de tijd [dag] voor $C$ en $R$ bij $D, M$ en W. Symbolen als in Fig. I. De lijnen zijn op het oog getekend.

$\mathrm{M}$, but gradually the scores went up to 4 . On the lower leaves, the infection type scores were usually one scale unit lower than the scores on flag leaves.

Pustule size. The largest pustules were found on plants at $\mathrm{D}$, whereas at $\mathrm{M}$ the pustules were relatively small (Table 5). An analysis of variance showed a significant effect of time as well as of water potential treatment, both at the $1 \%$ level.

Percentage of infection. Table 6 shows the percentages of infection versus time for each water potential treatment. The figures only represent the leaf area disrupted by open pustules, and they are calculated as weighed averages per leaf level per plant. Multiplication of these figures by the corresponding leaf area data per plant yields the total rusted area per plant. At $M$, the percentage of infection is lower than at D or W.

Spore production. Spore production (Fig. 4) was lowest at M, more at D, and highest at $\mathrm{W}$. The effect of the second inoculation on spore production at $\mathrm{W}$ was more prominent than at $M$. 
Table 4. Parameter values estimated by means of the calculation of the regression of dry matter and transpiration data $\left[10^{-3} \mathrm{~kg}\right.$ ] on time [day]. The regression equations (REGR) used are given in the table. For symbols see Table 2. A * means that no relevant value has been estimated, due to certain properties of the computer programme used. It indicates that the variance of the data in comparison to the increase with time was too large to calculate a proper estimate. The regression curves are shown in Fig. 1 and 2. The transpiration regression was done from day 28 to harvest.

\begin{tabular}{|c|c|c|c|c|c|c|c|c|}
\hline & & \multicolumn{2}{|l|}{$\mathbf{D}$} & \multicolumn{2}{|l|}{$\mathbf{M}$} & \multicolumn{2}{|l|}{$\mathbf{w}$} & \multirow[t]{2}{*}{ REGR } \\
\hline & & C & $\mathbf{R}$ & $\mathrm{C}$ & $\mathbf{R}$ & $\mathrm{C}$ & $\mathbf{R}$ & \\
\hline roots & $\mathbf{a}$ & 1.0 & 0.8 & 0.9 & 1.1 & 1.2 & 0.7 & $y=a$ \\
\hline \multirow[t]{3}{*}{ leaves } & $\mathbf{a}$ & 1.01 & 1.47 & 1.68 & 1.85 & 3.65 & 2.54 & $y=a+b e^{c x}$ \\
\hline & b & $*$ & $*$ & -6.17 & $*$ & -11.80 & $\neq$ & \\
\hline & c & $*$ & * & -0.051 & $*$ & -0.041 & $*$ & \\
\hline \multirow[t]{3}{*}{ stems } & $\mathbf{a}$ & 10.26 & 6.08 & 15.48 & 7.31 & 18.47 & 9.61 & $y=a+b e^{c x}$ \\
\hline & b & -13.70 & -12.90 & -20.24 & -41.91 & -27.18 & -22.80 & \\
\hline & c & -0.011 & -0.025 & -0.009 & -0.041 & -0.012 & -0.024 & \\
\hline \multirow[t]{3}{*}{ heads } & $\mathbf{a}$ & 2.77 & 26.59 & -9.48 & -3.76 & -5.02 & -3.36 & $y=a+b e^{c x}$ \\
\hline & b & 0.70 & -36.14 & 4.35 & 0.91 & 1.23 & 0.81 & \\
\hline & $\mathrm{c}$ & 0.028 & 0.005 & 0.014 & 0.025 & 0.023 & 0.022 & \\
\hline transpi- & $\mathrm{a}$ & -1940 & -1782 & -3060 & -3300 & -4310 & -3460 & $y=a+b x^{c x}$ \\
\hline ration & b & 61.7 & 59.6 & 88.5 & 95.3 & 131 & 111 & \\
\hline
\end{tabular}

Tabel 4. Parameterwaarden geschat door middel van de berekening van de regressie van droge stof en transpiratiemetingen $\left[10^{-3} \mathrm{~kg}\right]$ op de tijd [dag]. De gebruikte regressievergelijkingen (REGR) zïn in de tabel vermeld. Voor de symbolen zie Tabel 2. Een* betekent dat geen relevante schatting is gemaakt wegens bepaalde eigenschappen van het gebruikte computerprogramma. Het betekent hier, dat de varian tie in de gegevens in verhouding tot de toename in de tijd te groot was voor een goede schatting. De regressiecurven zijn te zien in Fig. I en 2. De regressie van de transpiratie gebeurde vanaf dag 28 tot de oogst.

Table 5. Mean pustule size $\left[10^{-9} \mathrm{~m}^{2}\right]$ of pustules on the second leaves of rusted plants versus time (t) at D, M and W. For the symbols see Table 1.

\begin{tabular}{lrll}
\hline$t$ & D & M & W \\
49 & 51 & 43 & 48 \\
56 & 87 & 54 & 65 \\
63 & 105 & 86 & 87 \\
70 & 104 & 77 & 99 \\
\hline
\end{tabular}

Tabel 5. Gemiddeld oppervlak van uredosori $\left[10^{-9} \mathrm{~m}^{2}\right]$ op het tweede blad van met roest geinfecteerde planten tegen de tijd $(t)$ bij $D, M$ en $W$. Voor symbolen zie Tabel 1 .

Table 6. Percentage of infection of plants at $\mathrm{D}, \mathrm{M}$ and $\mathrm{W}$ versus time. The figures are weighed means. For each leaf layer, the estimated percentage of infection was multiplied by the corresponding leaf area, and the sum of the products was divided by the total leaf area per plant.

\begin{tabular}{llll}
\hline $\mathbf{t}$ & D & M & W \\
49 & 3.5 & 1.4 & 3.0 \\
56 & 8.9 & 1.4 & 5.8 \\
63 & 7.2 & 1.6 & 3.3 \\
70 & 7.0 & 2.9 & 2.2 \\
84 & 6.0 & 4.4 & 5.5 \\
\hline
\end{tabular}

Tabel 6. Het percentage aantasting van de planten bij $D, M$ en $W$ tegen de tijd. De getallen zijn gewogen gemiddelden per plant, berekend na bepaling van het aantastingspercentage per bladlaag en vermenigvuldigd met het bijbehorend bladoppervlak. De zo verkregen getallen werden opgeteld en gedeeld door het totale bladoppervlak per plant. 
Fig. 3a. Mean transpiration [kg.plant ${ }^{-1}$ ] in $\mathrm{C}$ and $\mathrm{R}$ at $\mathrm{D}, \mathrm{M}$, and $\mathrm{W}$, versus time (t) [day] in the period from planting to harvest. For symbols see Fig. 1. Parameter values of the regression curves are given in Table 4.

Fig. 3b. Mean transpiration difference [kg.plant $\left.{ }^{-1}\right]$ between $C$ and $R$ at $D, M$, and $\mathbf{W}$, versus time (t) [day] in the period from day 49, one week after the first inoculation, to harvest. Arrows indicate inoculations. $\downarrow 1$ : first inoculation, $\downarrow 2 \mathrm{M}$ : second inoculation on $\mathbf{R}_{\mathrm{M}}, \downarrow 2 \mathrm{~W}$ : second inoculation on $R_{\mathrm{w}} \cdot \mathrm{D}-=(\mathrm{C}-\mathrm{R})_{\mathrm{D}}, \Delta \cdots=(\mathrm{C}-\mathrm{R})_{\mathrm{M}}, \mathrm{D} \ldots=(\mathrm{C}-\mathrm{R})_{\mathrm{w}}$.

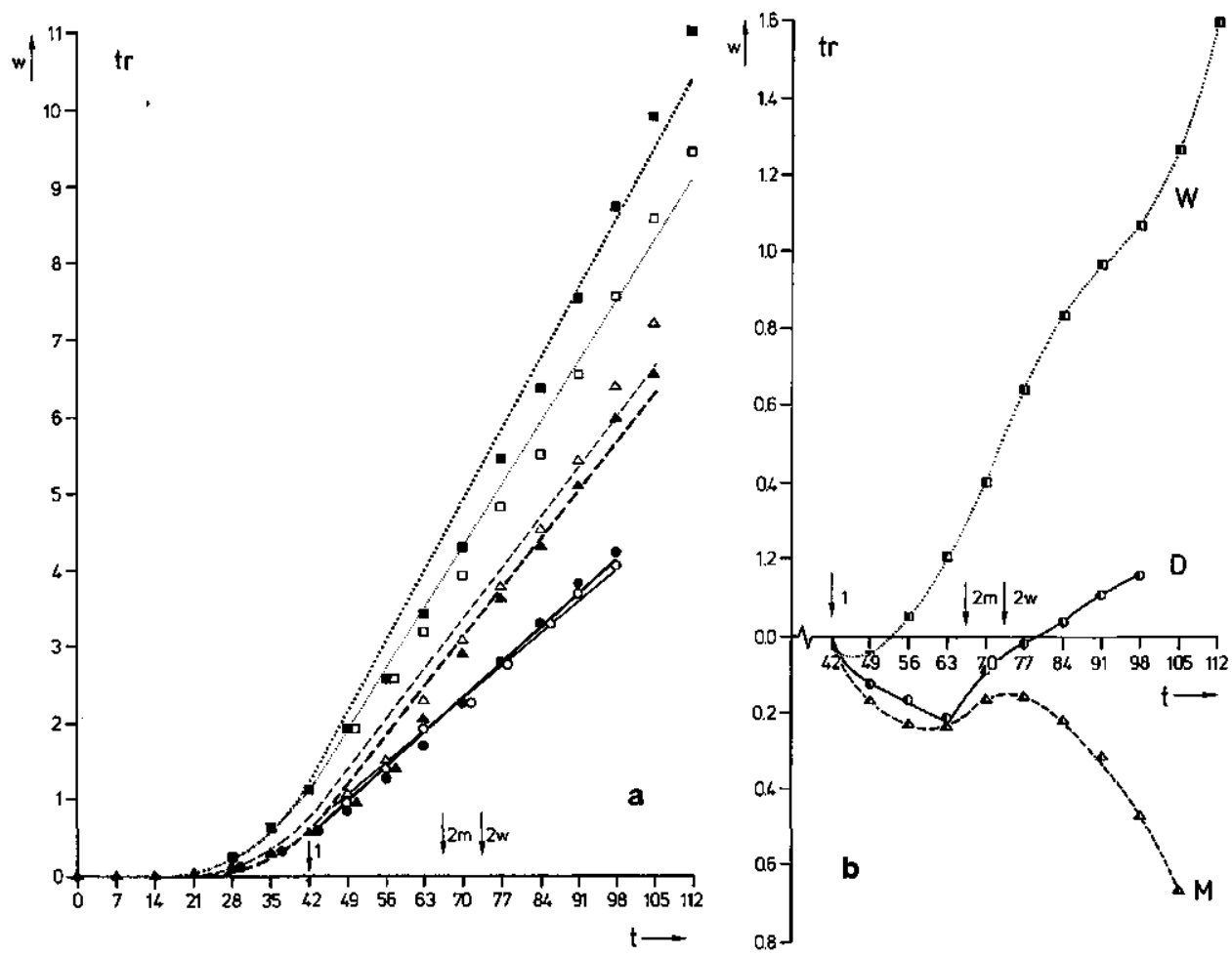

Fig. 3a. Gemiddelde transpiratie [kg.plant ${ }^{-1}$ ] van $C$ en $R$ voor $D, M$ en $W$ tegen de tijd ( $\left.t\right)$ [dag], van het uitplanten tot de oogst. Voor symbolen zie Fig. 1. De parameters van de regressiecurven worden gegeven in Tabel 4.

Fig. $3 b$. Gemiddeld verschil in transpiratie $\left[k g . p l a n t^{-1}\right]$ tussen $C$ en $R$ voor $D, M$ en $W$, tegen de tijd ( $\left.t\right)$ [dag] vanaf dag 49, eén week na de eerste inoculatie, tot de oogst. Pijlen geven inoculaties aan. $\downarrow 1$ : eerste inoculatie, $\downarrow 2 M$ : tweede inoculatie bij $R_{\mathrm{M}}, \downarrow 2 W$ : tweede inoculatie bij $R_{\mathrm{w}} . \boldsymbol{D}=(C-R)_{\mathrm{D}}$, $\left.\Delta \cdots=(C-R)_{\mathrm{M}}, 1\right] \ldots=(C-R)_{\mathrm{w}}$.

Resistance. When the figures of the responses of infection type, pustule size, and spore production are considered, they all indicate a more resistant reaction of the rusted plants at $M$, as compared with $\mathrm{D}$ and $\mathrm{W}$.

Summary of results. The various aspects of the 'behaviour' of the uninfected and the diseased plant can be summarized as follows. From day 28 onwards, transpiration and leaf area had been greater at higher water potentials. Development was retarded at wetter soils. Increase in growth rate was related to decrease in 'development rate'. At the time of the first inoculation (day 42), leaf area per plant differed already. At D 
Fig. 4. Mean spore production (w) $\left[10^{-5} \mathrm{~kg}^{-p l a n t} \mathrm{t}^{-1}\right]$ of rusted plants at $D, M$, and $W$ versus time (t) [day] in the period from day 49, one week after inoculation, to harvest. Symbols as in Fig. 1 and 3.

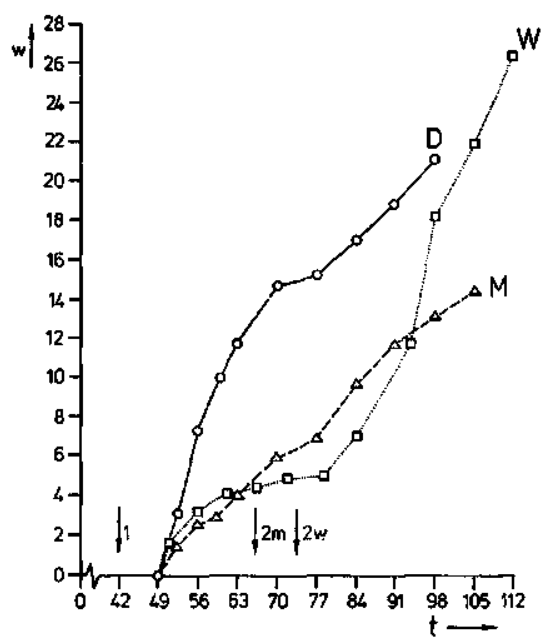

Fig. 4. Gemiddelde sporenproduktie (w) $\left[10^{-5} . \mathrm{kg}_{\text {.plant }}{ }^{-1}\right]$ van planten geinfecteerd met roest bij $D, M$ en $W$ tegen de tijd ( $t)$ [dag] vanaf dag 49,éen week na inoculatie tot de oogst. Symbolen als in Fig. I en 3.

and $M$, approximately half of the estimated maximum leaf area was reached by then, at $\mathrm{W}$ only $40 \%$. Only at $\mathrm{D}$ the flag leaves were just visible. All plants were subjected to an equally dense 'shower' of spores. Seven days later, the percentage of infection at $M$ was considerably lower than at $D$ and $W$; the latter two did not differ much from each other in this respect. Because of the great reproducibility of the inoculation technique itself, the difference in percentage of infection can be explained as a difference in resistance. The increase in percentage of infection at $M$ after the first inoculation was negligible, as compared with that at $\mathrm{D}$ and $\mathrm{W}$. These figures suggest a higher resistance of plants at $M$ as compared with those at $D$ and $W$.

Transpiration of $\mathbf{R}$ had been greater than of $\mathbf{C}$ at all water potentials during the first seven days after inoculation. During the second week after inoculation, the transpiration of $\mathbf{R}$ at $\mathbf{W}$ was lower than that of $\mathbf{C}$, related with lower scores of turgescent leaf area and stem weights of $\mathrm{R}$. Growth had also been hampered by the rust. At $D$ and $M$, transpiration of $R$ was greater than that of $C$. At $D$, this remained so for a period of 35 days after inoculation, and at $M$ for the full period after inoculation to harvest.

At D, rust grew rapidly; the percentage of infection increased and the sporulation rate was high. From day 63 , and especially in the period from day 70 to day 77 , sporulation rate was reduced. This coincides with an almost abrupt change in the transpiration figure of the difference $C-R$, and the beginning of a faster reduction in turgescent leaf area of $\mathbf{R}$ than of $\mathbf{C}$. In the following period, the uninfected plant transpired more than the rusted plant at $\mathrm{D}$. Sporulation rate is constant in that period, but lower than in the period before day 63 .

At $\mathrm{M}$, the growth of the rusted plant outrated the increase of the rusted area. The transpiration rate of $\mathbf{R}$ came again near to that of $\mathbf{C}$, but, as result of the second 
Table 7. Mean kernel weight $\left[10^{-3} \cdot \mathrm{kg} \cdot\right.$ plant $\left.^{-1}\right]$, mean kernel number [plant $\left.{ }^{-1}\right]$ and average kernel weight $\left[10^{-6} \cdot \mathrm{kg}_{\mathrm{kernel}}{ }^{-1}\right]$ determined at harvest time for each of the six combinations of treatment levels.

\begin{tabular}{|c|c|c|c|c|c|c|c|c|c|}
\hline & \multicolumn{3}{|c|}{ Kernel weight } & \multicolumn{3}{|c|}{ Kernel number } & \multicolumn{3}{|c|}{ Average kernel weigh } \\
\hline & D & $\mathbf{M}$ & W & D & $\mathbf{M}$ & W & $\mathbf{D}$ & $\mathbf{M}$ & W \\
\hline C & 6.2 & 7.3 & 7.8 & 174 & 189 & 202 & 35.7 & 38.6 & 38.7 \\
\hline $\mathbf{R}$ & 3.9 & 6.6 & 4.5 & 117 & 198 & 154 & 33.5 & 33.4 & 29.3 \\
\hline
\end{tabular}

Tabel 7. Gemiddeld korrelgewicht $\left[10^{-3} \cdot \mathrm{kg}_{\text {plant }}{ }^{-1}\right]$, gemiddeld korrelaantal $\left[\right.$ plant $\left.{ }^{-1}\right]$ en het gemiddeld korrelgewicht $\left[10^{-6} . \mathrm{kg}_{\text {.kernel }}{ }^{-1}\right]$ bepaald bij de oogst voor elk van de zes combinaties van behandelingsniveaus.

infection, the rusted plants transpired much more than $\mathrm{C}$, and this remained so until harvest. Sporulation rate increased after the second inoculation.

At $W$, the lower leaves lost their turgor rapidly from the second week after inoculation onwards. After day 56, the transpiration of the uninfected plant was greater than that of $\mathrm{R}$. The growth of the heads was slowed down. A slight increase in transpiration rate of $R$ was visible in the period from day 77 to 91 , coinciding with an increase in sporulation rate. The sporulation rate decreased slightly in the period from day 98 to harvest time, in which period the difference in transpiration $\mathbf{C}-\mathbf{R}$ increased further.

Where the transpiration of the rusted plant was initially greater and later lower than that of the control (at $D$ and $W$ ), the kernel number of $R$ was reduced. Only at $M$, kernel number of $R$ was not lower than that of $C$.

In conclusion, morphogenesis of the wheat plant was largely affected by soil-water potential. In the case of drier soils, the development stages succeeded each other with shorter intervals, and axial development was reduced. Growth and transpiration became less at lower soil-water potentials. In the case of the rusted plants, lowest scores of percentage of infection, infection type, pustule size, and spore production were obtained at the intermediate soil-water potential $\mathbf{M}$. The pattern of transpiration of rusted plants after infection was related to soil-water potential, but in all cases transpiration increased during the first week after infection. No reduction in kernel number by rust infection was found at $\mathbf{M}$; yield reduction was minimal at $\mathbf{M}$ too, whereas considerable reductions in kernel number and yields were found at the other two water potentials.

\section{Discussion}

The three groups of plants showed differences in appearance greater than the usual differences between cultivars grown commercially in any particular area. Visitors often hardly believed that all plants belonged to the same cultivar and that the difference had been induced by varying soil-water potential only. In the present paper, as in the previous one (Van der Wal and Cowan, 1974), the ripening of the plants differed from that of a "normal' crop in the field. Heat damage by the lamps led to early maturation of the heads (French: échaudage).

The effects of water potential on morphogenesis and resistance have been shown 
beyond doubt within the framework of the situational factors chosen, i.e. under the conditions and with the cultivar-race combination described here. It is not known whether the conclusions with respect to resistance can be generalized and applied to other cultivars and other environmental conditions. Apparently, conditions for growth of the rust were different in the leaves of plants grown at different water potentials. These differences in growth conditions can be attributed to differences in physical properties of the leaves like leaf water potential and/or to differences in morphological and chemical composition of the leaves. There are two indications for effects of soilwater potential on the plant water potentials. Firstly, the transpiration of rusted plants increased after infection during the first week, as was found before (Van der Wal and Cowan, 1974). Secondly, the yield figures show a reduction of the number of kernels per plant of rusted plants at $\mathrm{D}$ and $\mathrm{W}$, but not at $\mathrm{M}$. Under the present environmental conditions, 'water stress' was likely to occur (Fischer, 1973). The plants grown at the three levels of soil-water potential apparently differed enough in 'state' to show different responses to the 'extra water stress' caused by the rust infection.

\section{Samenvatting}

Een ecofysiologische benadering van 'schade', geillustreerd aan het systeem tarwe, bruine roest en kafjesbruin.

III. Effecten van de waterpotential van de grond op ontwikkeling, groei, transpiratie, symptomen en sporenproduktie van tarweplanten, geïnfecteerd met bruine roest

De invloed van een milieufactor, de waterpotentiaal van de grond, op de ontwikkeling en groei van de tarweplant, en op de waard-parasiet verhouding, werd onderzocht onder klimaatkamer-omstandigheden. Niet geïnfecteerde planten (C) werden vergeleken met planten die met roest geïnfecteerd waren (R). De waterpotentiaal werd gesteld op drie niveaus: $-1025 \mathrm{~J} . \mathrm{kg}^{-1}$ (D, droog, nabij het verwelkingspunt), -425 J. $\mathrm{kg}^{-1}$ (M, matig nat, een tussenwaarde), en $-250 \mathrm{~J} . \mathrm{kg}^{-1}$ (W, nat, nabij het verzadigingspunt).

Er werd een duidelijk effect van de waterpotentiaal op de ontwikkeling, groei en transpiratie van de tarweplant (zomertarwe, 'Kolibri') gevonden. De planten doorliepen de opeenvolgende ontwikkelingsstadia met kortere tussenpozen naarmate de waterpotentiaal lager was (Tabel 1). Ook werd de ontwikkeling van zij-assen minder bij afnemende waterpotentiaal. Groei en transpiratie waren geringer bij lagere waterpotentialen (Fig. 1 en 2, Tabel 2 en 3).

Infectietype, aantastingsgraad, maat van sporenhoopjes en sporenproduktie werden beinvloed door de waterpotentiaal van de grond. De laagste waarden werden waargenomen voor geïnfecteerde planten die groeiden bij $-425 \mathrm{~J} . \mathrm{kg}^{-1}(\mathrm{M})$. Dit duidt op een verschil in resistentie tussen de planten, gerelateerd aan de waterpotentiaal van de grond waarop zij groeiden (Fig. 3, Tabel 5 en 6).

Verschillen in waterpotentiaal in de grond kunnen blijkbaar niet alleeen verschillen in ontwikkeling, groei en transpiratie van de plant, maar zij kunnen ook verschillen in resistentie van de plant teweegbrengen.

Het effect van de roestinfectie op de korrelopbrengst bleek eveneens samen te hangen met de waterpotentiaal (Tabel 7). Bij alle drie waterpotentialen verminderde het gemiddeld korrelgewicht door de roest en bij D en W ook het korrelaantal, maar niet 
bij $M$. Het verloop van het verschil in transpiratie tussen $C$ en $R$, het patroon in de afname van het turgescente bladoppervlak, en het effect van de roest op het korrelaantal, doen vermoeden dat bij roestinfectie ook veranderingen van de waterpotentialen in de plant (zoals het turgescent blijven van nog niet gekoloniseerd plantweefsel, het al dan niet afstoten van jonge vruchten) van belang zijn bij het ontstaan van 'schade'.

\section{Acknowledgments}

The authors are indebted to $\mathrm{Mr} \mathrm{A}$. H. Gerritsen for his interest and assistance in the operation of the climate chamber. The services of the Drawing Office and the University Computer Centre are much appreciated. Mr H. J. A. van Beckum's correction of the English text is gratefully mentioned. Dr J. C. Zadoks' continuous interest has been stimulating.

\section{References}

Boyer, J. S., 1969. Measurement of the water status of plants. Ann. Rev. Plant Physiol. 20: 351-364. Cowan, M. C. \& Zadoks, J. C., 1973. Relations between soil water potential and disease in wheat seedlings infected by Puccinia recondita. Neth. J. Pl. Path. 79: 1-4.

Fischer, R. A., 1973. The effect of water stress at various stages of development on yield processes in wheat: In: Plant response to climatic factors. Ecology and conservation. Proc. Uppsala Symp. 1970, 5, pp. 233-241, Unesco 1973.

Gates, D. M., 1968. Transpiration and leaf temperature. Ann. Rev. Plant Physiol. 19: 211-248.

Johnston, C.D. \& Miller E. C., 1940: Modification of diurnal transpiration in wheat by infections of Puccinia triticina. J. Agric. Res. 61 (6): 427-444.

Mehta, Y. R. \& Zadoks, J. C., 1970. Uredospore production and sporulation period of Puccinia recondita f.sp. triticina on primary leaves of wheat. Neth. J. PI. Path. 76: 267-276.

Wal, A. F. van der \& Cowan, M. C., 1974. An ecophysiological approach to crop losses exemplified in the system wheat, leaf rust, and glume blotch. II. Development, growth, and transpiration of uninfected plants and plants infected with Puccinia recondita f. sp. triticina and/or Septoria nodorum in a climate chamber experiment. Neth. J. Pl. Path. 80: 192-214.

Weiss, F., 1924. The effect of rust infection upon the water requirement of wheat. J. Agric. Res. 27: $107-118$.

Zadoks, J. C., Chang, T. T. \& Konzak, C. F., 1974. A decimal code for the growth stages of cereals. Eucarpia Bull. 7, 10 pp.

\section{Address}

Laboratorium voor Fytopathologie, Landbouwhogeschool, Binnenhaven 9, Wageningen, the Netherlands. 


\title{
An ecophysiological approach to crop losses, exemplified in the system wheat, leaf rust and glume blotch ${ }^{1}$ \\ IV. Water flow and leaf-water potential of uninfected wheat plants and plants infected with Puccinia recondita f.sp. triticina
}

\author{
M. C. COWAN ${ }^{1}$ and A. F. VAN DER WAL \\ Laboratory of Phytopathology, Agricultural University, Wageningen
}

Accepted 12 September 1974

\begin{abstract}
Effects of leaf rust (Puccinia recondita Rob. ex Desm. f.sp. triticina Eriks.) infection of spring wheat (Triticum aestivum L.) plants 'Kolibri' on transpiration rate and leaf-water potential were studied during growth in a climate chamber at various soil-water potentials. The water potentials ranged from $-210 \mathrm{~J} . \mathrm{kg}^{-1}$ to $-1025 \mathrm{~J} . \mathrm{kg}^{-1}$. Rust infection has been found to increase the transpiration rate. The magnitude and duration of the increase depended on soil-water potential and the time (growth stage) of inoculation.

The transpiration rate of uninfected heads was affected by rust infection of the leaves, also depending on soil-water potential and infection time. Overall resistance of the plants to water flow was determined; sudden changes in resistance due to rust infection concur with high crop losses due to abortion of kernels. Leaf-water potentials were calculated and found to vary in uninfected plants from $-1740 \mathrm{~J} . \mathrm{kg}^{-1}$ at the lowest soil-water potential to $-580 \mathrm{~J} . \mathrm{kg}^{-1}$ when water was plentiful. At high soil-water potential, the leaf-water potential of rusted plants was lower than that of uninfected plants, but this was not so at low soil-water potentials. The effects of leaf-water potential on rust growth and water flow through leaves and heads are discussed. Suggestions about the application of the results to breeding for tolerance (= resistance to loss) and, eventually, to prevention of loss by rust in semi-arid areas are given.
\end{abstract}

\section{Introduction}

Water moves from the soil through the plant to the atmosphere along a gradient of potential energy (Boyer, 1969). The rate of water flow is determined by the magnitude of this potential gradient and the resistances along the path of movement. When water is plentiful in the soil, the major resistance to water flow is at the plant-air

${ }^{1}$ I. A simple and accurate balance for the continuous measuring and recording of (evapo-)transpiration of plants in indoor experiments. Neth. J. Pl. Path. 80 (1974) 77-84 (P. Tegelaar and A. F. van der Wal).

II. Development, growth, and transpiration of uninfected piants and plants infected with Puccinia f.sp. triticina and/or Septoria nodorum in a climate chamber experiment. Neth. J. Pl. Path. 80 (1974) 192-214 (A. F. van der Wal and M. C. Cowan).

III. Effects of soil-water potential on development, growth, transpiration, symptoms, and spore production of leaf rust infected wheat. Neth. J. PI. Path. 81 (1975) 1-13 (A. F. van der Wal, H. Smeitink and G. C. Maan).

${ }^{2}$ Visiting research worker in grant of a fellowship of the Royal Society, London. 
boundary. As soil-water potential declines, the resistance to water movement in the soil becomes an important part of the overall resistance to water flow (Rijtema, 1965; Yang and De Jong, 1972).

In uninfected plants, the rate of transpiration and of water uptake are controlled by the adjustment of resistance in the stomata and in the roots (Hopmans, 1971). After inoculation of wheat (Triticum aestivum L.) leaves with leaf rust (Puccinia recondita Rob. ex. Desm f.sp. triticina Eriks.), the transpiration rate of the infected plants increases (Van der Wal and Cowan, 1974; Van der Wal et al., 1975). This increase apparently caused by decrease in the resistance at the leaf-air boundary, may affect the leaf-water potential, and possibly the rate of photosynthesis. After heading the separate effects of leaf infection on water flow through the leaves, and on water flow through the heads can be considered.

In this paper an attempt is made to estimate these two flows in uninfected plants and in plants with rusted leaves. Leaf-water potentials are calculated for these plants grown at various soil-water potentials.

\section{Materials and methods}

The experimental data discussed here are those obtained in previous experiments. The treatment 'extra wet' $\left(\mathrm{EW}=\mathrm{c} .-210 \mathrm{~J} \cdot \mathrm{kg}^{-1}\right)$ was described by Van der Wal and Cowan (1974), the treatments 'wet' (W= c. $\left.-250 \mathrm{~J} . \mathrm{kg}^{-1}\right)$, 'medium' $(\mathrm{M}=\mathrm{c} .-425$ $\left.J . \mathrm{kg}^{-1}\right)$, and 'dry' $\left(\mathrm{D}=\mathrm{c} .-1025 \mathrm{~J} . \mathrm{kg}^{-1}\right)$ were described by Van der Wal et al. (1975). The lowest water potential was near the wilting point for wheat. Leaf-water potential was calculated using the equation of Gardner and Ehlig (1962) for plants in pot experiments:

$\psi_{1}-\psi_{\mathrm{s}}=\mathbf{E}_{\mathrm{t}}\left(\mathbf{R}_{\mathrm{pl}}+\mathrm{b} / \mathrm{k}\right)$

where $\psi_{1}=$ leaf-water potential $\left[\mathrm{J} \cdot \mathrm{kg}^{-1}\right], \psi_{\mathrm{s}}=$ soil-water potential $\left[\mathrm{J} \cdot \mathrm{kg}^{-1}\right], \mathrm{E}_{\mathrm{t}}=$ transpiration rate $\left[\mathrm{kg} \cdot \mathrm{m}^{-2}\right.$.day $\left.{ }^{-1}\right], \mathbf{R}_{\mathrm{pl}}=$ resistance to liquid flow through the plant [day], $b=a$ function of root density and rooting depth [m], $\mathrm{k}=$ soil capillary conductivity $\left[\mathrm{m} \cdot \mathrm{day}^{-1}\right]$. Inserting the dimension $\left[\mathrm{m}^{3}\right]$ in place of the dimension $[\mathrm{kg}]$ the conductivity values expressed as $\left[\mathrm{kg} \cdot \mathrm{m}^{-2} \cdot \mathrm{day}^{-1}\right]$ can be approximated as $\left[\mathrm{m} \cdot d a y^{-1}\right]$.

Direct measurement of leaf-water potential by thermocouple psychrometry (Spanner, 1951; Monteith and Owen, 1958) was considered. Among the dificulties discussed more fully by Boyer (1969) are the generation of heat and water vapour as products of respiration, especially in heavily infected samples of leaf tissue (Shaw and Samborski, 1957). The relation between capillary conductivity $\mathrm{k}$ and soil-water potential for peat soil (Rijtema, 1965) leads to an estimate of k of $2 \times 10^{-6} \mathrm{~m}_{\text {.day-1 }}^{-1}$ for treatment EW, $1.7 \times 10^{-6} \mathrm{~m}_{\text {.day }}{ }^{-1}$ for W, $10^{-6} \mathrm{~m}_{\text {day }}{ }^{-1}$ for $\mathrm{M}$, and $0.2 \times$ $10^{-6} \mathrm{~m}^{-d_{a y}-1}$ for $D$. The value of $b$ was estimated to be less than $10^{-3} \mathrm{~m}$, using the relation $\mathrm{b}=1 / 4 \pi \mathrm{az}$ (Rijtema, 1965) where $\mathrm{a}$ is the root density $\left[\mathrm{m}^{-2}\right]$ in metres root length per $\mathrm{m}^{3}$ soil, and $\mathrm{z}$ is the rooting depth $[\mathrm{m}]$. Estimates for root density were obtained from root weight and root diameter data, whereas bucket depth was used for z. The maximum of $b / k$ in EW was 500 days. Yang and De Jong (1972) published values for $\mathbf{R}_{\mathrm{pl}}$ for wheat growing in an artificial environment, ranging from 32 to $59 \times 10^{3}$ days. At $\mathrm{EW}, \mathrm{W}, \mathrm{M}$, and $\mathrm{D}$, the values of $\mathrm{b} / \mathrm{k}$ were $500,590,1000$, and 5000 days, or c. $1 \%, 1.2 \%, 2 \%$ and $10 \%$ of $R_{p 1}$, respectively, and these values were entered into the calculation. 
From the data given by Yang and De Jong for 'Thatcher' growing in soil of high water potential at $24^{\circ} \mathrm{C}$ and $65 \%$ relative air humidity, $R_{p 1}$ was taken as $41 \times 10^{3}$ days.

\section{Results}

Transpiration of uninfected plants. Fig. 1 illustrates the relation between turgid leaf area and transpiration rate, both expressed per plant. At $\mathbf{D}$ and $\mathbf{M}$, the relation between leaf area and transpiration rate was approximately linear up to the time of the appearance of the first spikelets. Heading was not synchronous. In lower order axes, heads appeared earlier than in higher order ones. Leaf area was still increasing during the heading period. At $\mathrm{W}$ and $\mathrm{EW}$, leaf areas were 2 to 3 times those of $\mathrm{D}$ and $\mathrm{M}$, and the transpiration rate per unit leaf area decreased in the period before heading. The effect is probably the result of mutual shading of leaves and reduced ventilation. Just before heading, the transpiration rates per unit leaf area at $\mathrm{EW}, \mathrm{W}, \mathrm{M}$, and $\mathrm{D}$ were respectively $0.4,0.7,1.1$ and $1.4 \mathrm{~kg} \cdot \mathrm{m}^{-2}$. day ${ }^{-1}$.

The increase in transpiration rate during the heading period is partly caused by transpiration of the heads and peduncles, and partly by greater transpiration of the upper leaves. Physical considerations suggest that the latter effect was smaller than the former. With the progress of ripening, turgid leaf area decreased (lower leaves first) and the heads started yellowing. At any value of turgid leaf area, the difference in transpiration rate before and after heading can be attributed mainly to the transpiration of the heads.

If the experiment had been continued until complete ripeness of the plants, the transpiration rate/leaf area curve would have fallen to the origin (see Fig. 1, EW, rust). However, the last samples were taken when the three lowest order axes reached stage 92 (Van der Wal et al., 1975). A number of green or partly green heads and leaves were still present at that time. Early termination of the experiment explains the 'truncated' appearance of the upper parts of the graphs.

An estimate for the proportion of the plant water flow that moves through the heads can be derived from Fig. 1 by taking the difference in transpiration rate before and after heading at one leaf-area value. As an example, increase in transpiration $b+c$ (Fig. 1, M) is about half the total transpiration $a+b+c$. At the end of flowering or at the waterripe stage, head transpiration accounts for c. 30 to $40 \%$ of the total transpiration.

Transpiration of rusted plants. Rust infection initially increased transpiration rate (Fig. 1, circles). The size of the effect was related to the water potential of the soil.

At $M$, the transpiration rate of the leaves increased after rust infection. Apart from the rise in the level of transpiration, the shape of the curve for the infected plant was almost the same as that for the uninfected one. The transpiration rate of the heads seemed not to have changed, there was no reduction in kernel number, and the loss was only $9 \%$ (Van der Wal et al., 1975). Close examination of the curves suggests that the rise in transpiration after the first inoculation decreased gradually, but was restored after the second inoculation.

At $D$, the reduction in turgescent leaf area in the infected plant proceeded faster than in the uninfected plant, and the pattern of transpiration rate after heading deviated from that in the uninfected plant. The maximum value of transpiration in the

Neth. J. Pl. Path. 81 (1975) 
In dit artikel wordt verder ingegaan op de transpiratie van niet geïnfecteerde tarweplanten (Triticum aestivum L.) 'Kolibri' en planten geïnfecteerd met roest (Puccinia recondita Rob. ex Desm. f.sp. triticina Eriks.). Allereerst wordt het transpiratiepatroon van wel en niet geïnfecteerde planten vergeleken bij vier grondwaterpotentialen (Fig. 1). Bladoppervlak en transpiratiesnelheid, beide uitgedrukt per plant, werden tegen elkaar uitgezet. Bij de twee laagste waterpotentialen, $-1025 \mathrm{~J} . \mathrm{kg}^{-1}$ en -425 J. $\mathrm{kg}^{-1}$, zijn de transpiratiesnelheden recht evenredig met het bladoppervlak, althans tot het in aar komen. Bij de hogere waterpotentialen $\left(-250\right.$ en $\left.-210 \mathrm{~J} . \mathrm{kg}^{-1}\right)$ neemt de transpiratiesnelheid per eenheid van bladoppervlak af naarmate er meer blad gevormd wordt, waarschijnlijk als gevolg van onderlinge beschaduwing en geringere ventilatie van de bladeren.

Uit het verschil tussen de transpiratiesnelheid voor en na het in aar komen bij een gelijk turgescent bladoppervlak werd een schatting gemaakt van het aandeel van de aren in de transpiratie van de plant. Dit bleek 30 tot $40 \%$ te zijn bij het einde van de bloei/waterrijpheid.

Het transpiratiepatroon van de plant na infectie week minimaal af van dat van de niet geïnfecteerde plant bij een grondwaterpotentiaal van $-425 \mathrm{~J} . \mathrm{kg}^{-1}$. Alleen de grootte van de transpiratiesnelheid verschilde, niet de vorm van de curve (Fig. 1). Bij deze waterpotentiaal trad geen reductie op in het aantal korrels per plant en de schade was gering. Ook de resistentie was hier maximaal (Van der Wal et al., 1975). De berekende bladwaterpotentiaal was $-900 \mathrm{~J} \cdot \mathrm{kg}^{-1}$. Zowel bij de laagste als bij de twee hoogste grondwaterpotentialen week het transpiratiepatroon van de plant na infectie sterk af van dat van de niet geïnfecteerde plant. Bij -1025 en bij $-250 \mathrm{~J}^{\mathrm{kg}} \mathrm{kg}^{-1}$ trad reductie van het aantal korrels op, terwijl de schade aanzienlijk was. De berekende waterpotentialen in het blad waren 28 dagen na de eerste infectie respectievelijk -1485 en $-640 \mathrm{~J} . \mathrm{kg}^{-1}$ (Tabel 1). Bij $-210 \mathrm{~J} . \mathrm{kg}^{-1}$ nam het turgescent bladoppervlak snel af na infectie. Hoewel geen effect van de infectie op het korrelaantal werd gevonden, mogelijk omdat pas na de bloei was geïnfecteerd, bleek de schade groot te zijn (Van der Wal en Cowan, 1974). Een hoge bladwaterpotentiaal laat blijkbaar een relatief hoge groeisnelheid van de schimmel in het blad toe. Hierdoor wordt de transpiratie aanvankelijk sterk verhoogd, met snelle uitdroging van het blad als gevolg.

Aangezien groei van waardplant en pathogeen blijkbaar in hoge mate samenhangen met de waterpotentialen in het blad, kan een studie als deze bijdragen tot een beter begrip van tolerantie ( $=$ resistentie tegen schade). In semi-ariede gebieden zou misschien door irrigatie op het juiste ogenblik de schade als gevolg van roestaantastingen beperkt kunnen worden.

\section{Acknowledgments}

The authors are indebted to Dr P. A. M. Hopmans and Ir N. M. de Vos for their constructive criticism. Mr H. J. A. van Beckum's correction of the English text is gratefully mentioned. Dr J. C. Zadoks interest in the progress of the work was stimulating. 


\section{References}

Boyer, J. S., 1969. Measurement of the water status of plants. A. Rev. PJ. Physiol. 20: 351-364.

Cowan, M. C. \& Zadoks, J. C., 1973. Relations between soil-water potential and disease in wheat seedlings infected by Puccinia recondita. Neth. J. Pl. Path. 79: 1-4.

Doodson, J. K., Manners, J. G. \& Myers, A., 1965. Some effects of yellow rust (Puccinia striiformis) on ${ }^{14}$ carbon assimilation and translocation in wheat. J. exp. Bot. 16: 304-317.

Gardner, W. R. \& Ehlig, C. F., 1962. Impedance to water movement in soil and plant. Science 138: 522-523.

Hailey, J. L. et al., 1973. Resistance to water flow in Vigna sinensis L. (Endl.) at high rates of transpiration. Crop Sci. 13: 264-267.

Hopmans, P. A. M., 1971. Rhythms in stomata opening of bean leaves. Meded. Landbouwhogeschool Wageningen 71 (3): $86 \mathrm{pp}$.

Monteith, J. L. \& Owen, P. C., 1958. A thermocouple method for measuring relative humidity in the range $95 \%$ to $100 \%$. J. scient. Instrum. $35: 443-446$.

Puckridge, D. W., 1972. Photosynthesis of wheat under field conditions. V. The effect of solar elevation on the distribution of photosynthetic activity with the crop canopy. Aust. J. agric. Res 23: 397-404.

Rijtema, P. E., 1965. An analysis of actual evapotranspiration. Thesis Wageningen/Agric. Res. Rep. 659: $107 \mathrm{pp}$.

Shaw, M., 1964. The physiology and host-parasite relations of the rust. A. Rev. Phytopath. 2: 259294.

Shaw, M. \& Samborski, D. J., 1957. The physiology of host-parasite relations. III. The pattern of respiration in rusted and mildewed cereal leaves. Can. J. Bot. 35: 389-407.

Spanner, D. C., 1951. The Peltier effect and its use in the measurement of suction pressure. J. exp. Bot. 2: 145-168.

Wal, A. F. van der \& Cowan, M. C., 1974. An ecophysiological approach to crop losses, exemplified in the system wheat, leaf rust and glume blotch. II. Development, growth and transpiration of uninfected plants and infected with Puccinia recondita f.sp. triticana and/or Septoria nodorum in a climate chamber experiment. Neth. J. Pl. Path. 80, (1974) 192-214.

Wal, A. F. van der, Smeitink, Hanneke \& Maan, G. C., 1975. An ecophysiological approach to crop losses, exemplified in the system wheat, leaf rust and glume blotch. III. Effects of soil-water potential on development, growth, transpiration, symptoms, and spore production of leaf rust-infected wheat. Neth. J. Pl. Path. 81 (1975) 1-13.

Wit, C. T. de, 1958. Transpiration and crop yields. Versi. landbouwk. Onderz. 64 (6) $88 \mathrm{pp}$.

Yang, S. L. \& Jong, E. de, 1972. Effects of aerial environment and soil-water potential on the transpiration and energy status of water in wheat plants. Agron. J. 64: 574-578.

\section{Address}

Laboratorium voor Fytopathologie, Landbouwhogeschool, Binnenhaven 9, Wageningen, the Netherlands. 